\title{
KNOX-02RR: drilling site survey-life in subseafloor sediments of the South Pacific Gyre ${ }^{1}$
}

\author{
S. D'Hondt, ${ }^{2}$ L.J. Abrams, ${ }^{3}$ R. Anderson, ${ }^{4}$ J. Dorrance, ${ }^{5}$ A. Durbin, ${ }^{6}$ L. Ellett, $^{5}$ T. Ferdelman, $^{2}$ J. Fischer, $^{7}$ \\ S. Forschner, ${ }^{8}$ R. Fuldauer, ${ }^{9}$ H. Goldstein, ${ }^{5}$ D. Graham, ${ }^{2}$ W. Griffith, ${ }^{10}$ H. Halm, ${ }^{7}$ R. Harris, ${ }^{2}$ B. Harrison, ${ }^{11}$ \\ F. Hasiuk, ${ }^{12}$ G. Horn, ${ }^{13}$ J. Kallmeyer, ${ }^{2}$ M. Lever, ${ }^{6}$ J. Meyer, ${ }^{5}$ L. Morse, ${ }^{5}$ C. Moser, ${ }^{14}$ B. Murphy, ${ }^{5}$ \\ A. Nordhausen, ${ }^{7}$ L. Parry, ${ }^{5}$ R. Pockalny, ${ }^{8}$ A. Puschell, ${ }^{7}$ J. Rogers, ${ }^{8}$ H. Schrum, ${ }^{8}$ D.C. Smith, ${ }^{8}$ B. Soffientino, ${ }^{8}$ \\ A.J. Spivack, ${ }^{2}$ A. Stancin, ${ }^{12}$ M. Steinman, ${ }^{9}$ and P. Walczak ${ }^{14}$
}

\section{Chapter contents}

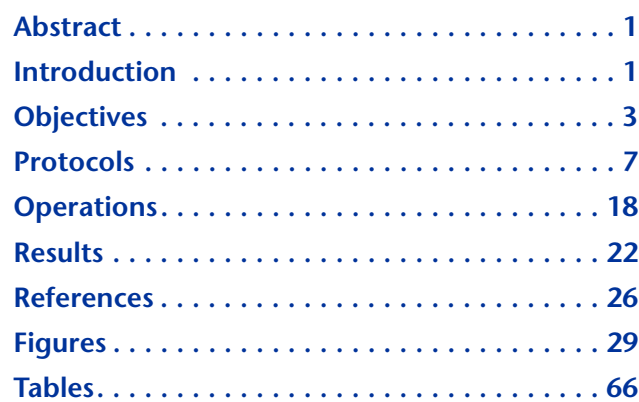

'D'Hondt, S., Abrams, L.J., Anderson, R., Dorrance, J., Durbin, A., Ellett, L., Ferdelman, T., Fischer, J., Forschner, S., Fuldauer, R., Goldstein, H., Graham, D., Griffith, W., Halm, H., Harris, R., Harrison, B., Hasiuk, F., Horn, G., Kallmeyer, J., Lever, M., Meyer, J., Morse, L., Moser, C., Murphy, B., Nordhausen, A., Parry, L., Pockalny, R., Puschell, A., Rogers, J., Schrum, H., Smith, D.C., Soffientino, B., Spivack, A.J., Stancin, A., Steinman, M., and Walczak, P., 2011. KNOX-02RR: drilling site survey-life in subseafloor sediments of the South Pacific Gyre. In D'Hondt, S., Inagaki, F., Alvarez Zarikian, C.A., and the Expedition 329 Scientists, Proc. IODP, 329: Tokyo (Integrated Ocean Drilling Program Management International, Inc.). doi:10.2204/iodp.proc.329.112.2011

'Expedition 329 Scientists' addresses.

Correspondence author: dhondt@gso.uri.edu

${ }^{3}$ University of North Carolina at Wilmington,

Wilmington NC 28403, USA.

${ }^{4}$ Carleton College, Northfield Minnesota 55057, USA. ${ }^{5}$ University of California San Diego, La Jolla CA 92093, USA. ${ }^{6}$ University of North Carolina at Chapel Hill, Chapel Hill NC 27599, USA.

${ }^{7}$ Max Planck Institute for Marine Microbiology, Bremen, Germany.

${ }^{8}$ University of Rhode Island, Narragansett RI 02882, USA.

${ }^{9}$ Florida Institute of Technology, Melbourne Florida 32901, USA.

${ }^{10}$ Carroll High School, Southlake TX 76092, USA.

${ }^{11}$ California Institute of Technology, Pasadena CA 91125, USA.

${ }^{12}$ University of Michigan, Ann Arbor MI 48109, USA.

${ }^{13}$ University of Southern California, Los Angeles CA 90089, USA.

${ }^{14}$ Oregon State University, Corvallis OR 97331, USA.

\section{Abstract}

The middle of the South Pacific Gyre is farther from continents and productive oceanic zones than any other site on Earth. To understand the nature of life in the most oxidized and food-limited subseafloor sediments, Cruise KNOX-02RR surveyed and cored sediment at ten sites throughout the South Pacific Gyre and one site at the southern margin of the gyre. Sediment at all of the South Pacific Gyre sites accumulated extraordinarily slowly for millions of years $(0.1-1 \mathrm{~m} / \mathrm{m} . \mathrm{y}$.).

Shipboard scientific results indicate that South Pacific Gyre sediments contain a living community characterized by very low biomass and very low metabolic activity. At every depth in the cored South Pacific Gyre sediments, cell abundances are 2-6 orders of magnitude lower than at the same depths in all previously explored subseafloor communities. The net rate of respiration by the subseafloor sedimentary community at each gyre site is 1-3 orders of magnitude lower than the rates of subseafloor communities at previously explored sites.

Because of the low rates of respiration, interstitial waters are oxic throughout the upper sediment column in most of this region. Consequently, the subseafloor sedimentary community of this region is predominantly aerobic to more than $8 \mathrm{~m}$ below the seafloor, unlike previously explored subseafloor communities. Generation of hydrogen by radiolysis of water may be a significant food source for this subseafloor community.

\section{Introduction}

This expedition to the South Pacific Gyre, identified as Cruise KNOX-02RR of the R/V Roger Revelle, was the first stage in a multistage program to explore the sediments that have accumulated extraordinarily slowly over tens of millions of years. KNOX-02RR departed Apia, Samoa, 17 December 2006 and ported in Dunedin, New Zealand, 27 January 2007. South Pacific Gyre sediments are farther from continents and productive oceanic zones than any other site on Earth. This exploration provided an unequaled opportunity to understand the nature of life in the most oxidized and food-limited sediments of Earth's ocean (D'Hondt et al., 2006). These sediments are relatively rich in cosmic debris and provide a direct terrestrial analog for slowly accumulating energy- 
poor sedimentary environments on other planetary bodies (such as subseafloor Europa and wet subsurface sediments of Mars). The expedition investigated the extent and nature of habitability and life in this ancient and energy-starved subsurface environment, including its extent of metabolic independence from the surface photosynthetic world.

This region contains the clearest seawater in the world (Morel et al., 2007). Its organic flux to the seafloor is lower (Jahnke, 1996), sedimentation is slower, and concentrations of cosmic debris are higher than anywhere else in the ocean. Preliminary studies indicate that water radiolysis is likely to be a significant source of electron donors in these sediments (D'Hondt et al., 2006). Biomass and rates of metabolic activities are likely to be very low, and subseafloor communities and activities are likely to be very different from all previously explored subseafloor sedimentary communities, which are principally fueled by organic matter from the surface world.

This expedition had three fundamental objectives:

- To survey broad characteristics of subseafloor communities and habitats in this region in order to refine the planning and objectives of drilling by Integrated Ocean Drilling Program (IODP) Expedition 329;

- To document the metabolic activities, genetic composition, and biomass of prokaryotic communities in shallow subseafloor $(\leq 8$ meters below seafloor [mbsf]) sediments with very low total activity; and

- To quantify the extent to which those communities may be supplied with harvestable energy by water radiolysis, a process independent of the surface photosynthetic world.

The expedition met these objectives by

1. Coring the upper sediment column at several sites along two transects in the region of the South Pacific Gyre;

2. Undertaking extensive microbiological, biogeochemical, geophysical, and geological analysis of the cores; and

3. Accurately surveying the geophysical (seismic, magnetic, bathymetric, and geothermal) characteristics of each site on both transects (Fig. F1).

Coring and geophysical surveys were undertaken during the expedition. Microbiological, biogeochemical, geological, and geophysical analyses were initiated during the cruise and continued long after the expedition ended in Dunedin, New Zealand.

Our results addressed several questions:
- Are the communities in mid-gyre subseafloor sediments uniquely structured?

- Do they contain previously unknown organisms?

- What are their principal sources of biologically utilized energy?

- Do their principal activities and composition vary with water depth, sediment composition, and other properties that co-vary with distance from ridge crest?

These questions can be framed as a series of hypotheses to be tested. For example, D'Hondt et al. (unpubl. data; www.nsf.gov/awardsearch/showAward.do? AwardNumber=0527167) hypothesized the following:

- Net metabolic activities are low, and oxygen $\left(\mathrm{O}_{2}\right)$ is the principal net terminal electron acceptor in the subseafloor ecosystem of mid-gyre sediments. Consequently, the diversity of anaerobic activities will be far less than in previously examined subseafloor sediments.

- The composition of the subseafloor sedimentary community in this province will be distinctly different from the communities observed in the higher activity anaerobic subseafloor ecosystems that have been examined to date.

- Current estimates of active subseafloor biomass are at least an order of magnitude too high because the abundance of active cells in this habitat is at least two orders of magnitude lower than current estimates of average cell concentrations in deep-sea sediments.

- Because organic flux to the mid-gyre seafloor is so low, radiolysis of water is a relatively significant source of microbially harvestable energy in this subseafloor environment.

The results of the KNOX-02RR survey cruise significantly advanced understanding of the subsurface world by testing the extent to which distinct oceanographic and geologic provinces contain distinct shallow subseafloor ( $\leq 8 \mathrm{mbsf}$ ) communities. Survey results also set the stage for documenting the extent to which life in these low-activity sediments depends on the surface photosynthetic world, and the extent, if any, to which it is metabolically independent of the surface world (e.g., Blair et al., 2007; Jørgensen and D'Hondt, 2006). These results place firm constraints on estimates of total subseafloor biomass.

To successfully undertake the broad range of research required by our objectives, our proponent group consisted of scientists from different institutions with very different areas of expertise (University of Rhode Island [URI], University of North Carolina at 
Chapel Hill [UNCCH], University of North Carolina at Wilmington [UNCW], University of Michigan [UM], Caltech, University of Southern California [USC], and Max Planck Institute [MPI] for Marine Microbiology [Bremen]). As described in our original proposal, the US-based scientists were funded by US National Science Foundation and the US National Aeronautics and Space Administration, whereas the MPI scientists were funded by the Max Planck Society for the Advancement of Science and the German National Science Foundation (DFG) IODP.

KNOX-02RR shipboard and postcruise studies fall into five general areas: geophysical survey, sedimentology, biogeochemistry, activity experiments, and microbiology. The following sections describe the principal objectives and protocols of each area of study.

\section{Objectives Geophysical objectives}

Our principal geophysical objectives were to locate potential coring locations and to characterize the tectonic setting, the sediment characteristics, and the potential for hydrologic processes at each coring site. These objectives were achieved with a suite of geophysical measurements, including multibeam bathymetry, seismic reflection profiling, magnetics, gravity, and heat flow.

\section{Seafloor mapping objectives}

Multibeam bathymetry surveys of each coring site were conducted with SIMRAD EM120 swath mapping system prior to coring and on-station operations. The primary goals of seafloor mapping were to

- Identify and locate coring sites and

- Characterize the tectonic, volcanic, and kinematic environment of the survey area.

Swath bathymetry data were used in real time during seismic surveys to identify regions of the seafloor where sediments were most likely to be imaged with seismic methods. These bathymetry data were later processed and gridded to generate regional views of the survey areas to determine the orientation (i.e., spreading direction) and roughness (i.e., approximate spreading rate) of original abyssal hill fabric. These bathymetric charts were also used to identify the presence and magnitude of off-axis volcanism.

Total magnetic field measurements were made with the SeaSPY Overhauser magnetometer/gradiometer during the approach and departure of each coring site. These data were used in real time to identify individual magnetic anomalies on approach to a new site. Additional forward modeling of the calculated anomalous magnetic field was used to calculate spreading rates and determine the kinematic environment of crustal accretion.

Postcruise activities included additional processing of the multibeam data at each station and creation of a complete catalog of multibeam and backscatter plots for each $3^{\circ}$ of transit.

\section{Seismic objectives}

Seismic surveys of each coring site were conducted with the Knudsen digitally recorded $3.5 \mathrm{kHz}$ seismic reflection system and multichannel seismic reflection (MCS) system using one or two 150 inch $^{3}$ generator injector (GI) guns (45 inch $^{3}$ generator chamber, 105 inch $^{3}$ injector) with a 48-channel digital streamer. The primary goals of the seismic surveys were to

- Locate suitable/representative coring sites,

- Estimate sediment thickness, and

- Identify potential lithologic variations within the seismic section.

Seismic surveys of 6 to $12 \mathrm{~h}$ duration were conducted and included crossing survey lines at/near the intended coring locations. Sediment thicknesses and potential sediment layers were determined from onscreen and hard copies of seismic sections. Additional postcruise seismic processing was conducted to generate stacked seismic sections from the MCS data.

\section{Heat flow objectives}

Thermal measurements were made to understand thermal processes at each coring site and to supplement the geophysical characterization of coring sites. This work is intended to address several questions:

- What is the thermal environment from which the cores are taken?

- What are the rates of advective heat flow and fluid flow through the sediments?

- What are the fluxes of heat through each coring site as a function of plate age, sediment thickness, and basement relief?

The coring sites (Fig. F2) span a broad range of tectonic settings, crustal conditions, and crustal ages. Tectonic settings include the East Pacific Rise ridge flank, the South Pacific abyssal plain, and the bathymetrically anomalous South Pacific Superswell (McNutt, 1998). Crustal ages range from $\sim 15$ to $>100 \mathrm{Ma}$ along the coring transects. These transects cross an area that is characterized by thin and discontinuous sediments and a relatively high population of sea- 
mounts (Wessel, 2001). All of these characteristics increase buoyancy-driving forces, promoting the likelihood of fluid flow through the crust and sediments (Harris et al., 2004).

Heat flow data within and near the South Pacific Gyre prior to the cruise are sparse (Fig. F2). Most of the existing heat flow data lie north of $20^{\circ} \mathrm{S}$, with little data near the northern and southern transects. The existing heat flow data are predominantly single, widely spaced probe measurements. Interpretations of heat flow data in the South Pacific Superswell suggest advective fluid flow (Stein and Abbott, 1991; McNutt, 1998).

\section{Sedimentology objectives}

Our principal sedimentological objective was to document the composition, distribution, approximate age-depth relationships, and biologically relevant physical properties (e.g., formation factor, porosity) of the subseafloor sedimentary habitats in the South Pacific Gyre region.

Additional (postcruise) objectives are to determine the histories of aeolian sedimentation and nutrient dynamics in the South Pacific Gyre. These studies entail

1. Developing detailed strontium isotope stratigraphies from ichthyoliths and carbonate microfossils (to refine estimates of sediment age, sedimentation rates, and mass accumulation rates),

2. Determining grain size of terrigenous extracts,

3. Using $\mathrm{Sr}-\mathrm{Nd}-\mathrm{Pb}$ isotopes for determining provenance of the terrigenous input (e.g., the sites are located in the trades and therefore may show a positive $\varepsilon_{N d}$ signature, indicative of the younger volcanics from the Andes), and

4. Determining carbon isotopic and elemental signatures of planktonic and benthic carbonate microfossils to explore the history of nutrient dynamics.

\section{Biogeochemistry objectives}

Our biogeochemical objectives included documenting the biogeochemical environment of the subseafloor sediments and shallow basaltic basement beneath the low-productivity South Pacific Gyre to identify the principal redox processes that occur in those sediments (e.g., D'Hondt et al., 2002, 2004), to quantify the rates at which those processes occur (D'Hondt et al., 2002, 2004), to calculate mineral stabilities and, where possible, test thermodynamic models of microbial competition (Hoehler et al., 1998; Wang et al., 2004) and quantify the potential of water radiolysis for supporting life in these clayrich sediments.
To meet these objectives, our shipboard analyses focused on determining dissolved concentrations of transitory compounds (e.g., $\mathrm{O}_{2}$ and $\mathrm{H}_{2}$ ) and compounds of special interest for documenting the biogeochemical environment and defining microbiological sampling strategies (e.g., $\mathrm{O}_{2}, \mathrm{NO}_{3}{ }^{-}$, and, for the southern transect, $\mathrm{SO}_{4}{ }^{2-}$ ). Also to meet these objectives, samples were taken for determining solidphase chemistry and concentrations of a diverse range of other dissolved chemicals postcruise.

The results of these studies will allow us to test our hypotheses that (1) net metabolic activities are low and oxygen $\left(\mathrm{O}_{2}\right)$ is the principal net terminal electron acceptor in this subseafloor ecosystem (and that consequently the diversity of anaerobic activities will be far less than in previously examined subseafloor sediments) and (2) radiolysis of water is a relatively significant source of microbially harvestable energy in this subseafloor environment.

\section{Objectives of activity experiments}

Distributions of metabolic products and isotopic signatures in pore waters and solid phases provide the basic information for estimating net microbial activities in subseafloor environments. However, not all processes are evident in the distributions of geochemical constituents. Metabolic reactants or products may be too low in concentration, indistinguishable from nonreacting components, or subject to secondary reactions that obscure the original signal. In certain cases, we can employ tracer experiments to reveal key underlying processes or activities.

In a classic tracer experiment, a compound that bears a radioactive or stable isotope of one of the elements in the compound of interest is added in trace (typically $<5 \%$ total concentration) amounts. In subseafloor sediments, we are time-limited and working at the edge of detection limits (i.e., we cannot perform experiments on geological timescales). Consequently, we are often compelled to add compounds at higher than typical concentrations. Furthermore, we manipulate the sediments in ways that may critically depart from in situ conditions. It needs to be emphasized that tracer experiments demonstrate potential activities. How close rates determined in an experiment reflect in situ rates and activities must be judged for every experiment. Nonetheless, in the search for microbial activity in the ultra-oligotrophic subseafloor ocean, tracer experiments may provide key insights or constraints on processes.

\section{Hydrogenase activity}

Hydrogenase enzymes are key components of all known biochemical pathways that involve hydrogen 
as a product or as a substrate. In typical sediments, virtually all of the dissolved hydrogen present in the interstitial water is produced biologically from anaerobic fermentation of organic matter. In the extremely organic poor clays of the South Pacific Gyre, hydrogen production from radiolysis of water may be a significant source of reducing power for microorganisms. Thus, measurement of hydrogenase activity is significant for understanding the activity of microorganisms in relation to the possible sources of energy in these sediments.

\section{Nitrogen cycling}

After respiration using dissolved oxygen, nitrate reduction to dinitrogen gas (denitrification) yields the most energy per mole of typical organic carbon compound (e.g., sugar) or hydrogen. Furthermore, reduced nitrogen compounds, principally ammonia, are released during decomposition of organic matter. Nitrification of dissolved ammonia with oxygen (or even with nitrate) may form a secondary and significant pathway of oxygen consumption in these ultraoligotrophic sediments. Nitrification and denitrification pathways can be identified by amending sediments with ${ }^{15} \mathrm{~N}$-labeled $\mathrm{NH}_{4}$ and $\mathrm{NO}_{3}{ }^{-}$, respectively, and then examining isotopic ratios in the $\mathrm{NO}_{3}{ }^{-}$and $\mathrm{N}_{2}$ produced during time-course experiments.

\section{Thymidine incorporation}

The incorporation of thymidine into DNA is a commonly used method to estimate microbial growth. In deep subsurface sedimentary samples, the method has been adapted for use in identifying zones of microbial activity. We inject ${ }^{3} \mathrm{H}$-labeled thymidine into subsamples from multicores and piston cores to determine the incorporation of tritium into DNA over a 3-day time course experiment.

\section{Cysteine degradation experiments}

Bacterial communities in abyssal sediments that can oxidize reduced sulfur compounds have been reported (Teske et al., 2000). These reports raise the question of the provenance of the reduced sulfur for such a metabolism. Abyssal sediments from the north-central Pacific also contain low but measurable concentrations of reduced sulfur minerals (Berelson et al., 1990). Reduced sulfur may originate during degradation of sulfur-containing amino acids such as cysteine or methionine.

\section{Microbiology objectives}

The principal objective of our microbiological studies was to characterize the composition and biomass of the living microbial communities in the relatively shallow subseafloor sediments of this oxic and organic-poor environment. To meet this broad objective, science party members are undertook many specific projects with narrower objectives. For example, individual postcruise studies are:

1. Examining trends in community composition within and between sites related to changing geochemical and lithological regimes and sediment age or depth,

2. Searching for evidence of selective patterns of microbial colonization on surfaces of specific sedimentary components (e.g., to determine if minerals, micrometeorites, and so on, provide key nutrients for microbial metabolism under oligotrophic conditions),

3 . Testing the role of microbes in formation of manganese nodules,

4. Documenting the potential isolation and connectedness of microbial communities in the sediment relative to that in the underlying basalt, and

5. Examining the biosynthetic potential of the microbial communities, among others.

To meet these objectives, we undertook select microbiological studies during the cruise and we are undertaking a diverse range of studies postcruise.

\section{Cell enumeration objectives}

The principal objective of our cell enumeration studies was to estimate the concentration of living biomass in these very organic poor subseafloor sediments and to develop a conservative estimate of the extent to which the observed cells from this environment are truly living and active. The first of these objectives was met by census of cells using DNA-specific stains (SYBR Green and acridine orange). To determine the extent to which counted cells are truly active, we took uncontaminated shipboard samples for postcruise catalyzed reporter deposition-fluorescence in situ hybridization (CARDFISH) counts on both bulk sediments and separated mineral components. This approach uses an oligonucleotide probe that hybridizes to a target rRNA molecule. Consequently, it differentiates metabolically active, rRNA-rich cells from rRNA-depleted, inactive, or dead cells. To determine if the cells are growing, bulk sediment samples were taken for incubations with a DNA nucleotide analog, bromodeoxyuridine (BrDU). Cells that take up BrDU will incorporate it into their DNA only during DNA synthesis, a key step in cell division.

The results of these studies have allowed us to test our hypothesis that current estimates of active subseafloor biomass (Whitman et al., 1998; Parkes et al., 2000) are far too high because the abundance of ac- 
tive cells in this habitat is at least two orders of magnitude lower than current estimates of average cell concentrations in deep-sea sediments (Kallmeyer et al., 2009).

\section{Molecular biological objectives}

Our principal molecular biological objectives were to determine the community composition, active members, potential activities, diversity, and distributions of microbial communities in the shallow subseafloor sediments of the South Pacific Gyre. Secondary molecular objectives included the characterization of microbial communities associated with manganese nodules and basaltic glass.

Postexpedition investigations into microbial diversity, as well as depth-related and geographic distribution patterns thereof, focused on 16S/18S rRNA and 16S/18S rRNA genes using polymerase chain reaction (PCR) (e.g., Durbin and Teske, 2010). Samples were also taken to

1. Target functional genes, including genes involved in carbon fixation and nitrogen metabolism, using PCR;

2. Detect biosynthetic gene clusters (polyketide synthase and nonribosomal peptide sythetase) through PCR amplification of whole sediment DNA extractions; and

3. Pursue further investigations into microbial activities and evolution using phi-29 polymerasemediated whole genome amplification and community metagenomics.

Finally, samples were taken to target select community members for population or single-cell genomics using cells extracted from bulk sediments and separated mineral components and sorted using flow cytometry. Extraction of DNA from separated mineral components is intended to assess microscalar variations in microbial diversity in the sediment column as a function of mineralogy and substrate composition.

The results of these and other studies will ultimately allow us to test our hypothesis that the composition of the subseafloor sedimentary community in this province is distinctly different from the communities observed in the higher activity anaerobic subseafloor ecosystems that have been examined to date.

\section{Cultivation objectives}

The unique nature of the sediments collected during the South Pacific Gyre coring expedition provides an opportunity to study potentially novel microbial diversity and adaptations to subsurface life. A principal objective of our cultivation experiments was to test the potential diversity of metabolic activities in these oxic and organic-poor subseafloor sediments. An additional objective was to determine the viability of aerobic heterotrophs in the sediment and to estimate the number of cultivable cells.

Recent studies have suggested that the deep ocean may harbor new genera of obligate marine microbes with extraordinary biosynthetic potential. Consequently, another objective of our studies was to extend knowledge of the cultivable marine actinobacteria from deep-ocean sediments. In particular, we cultivated Gram-positive bacteria from sediments collected during the South Pacific Gyre coring cruise to determine the phylogenetic affiliations of bacterial isolates and to assess the biosynthetic potential of selected Gram-positive isolates using genetic, chemical, and bioassay analyses.

\section{Objectives of manganese nodule studies}

The goal of our manganese nodule studies was to characterize the microbial community of the nodules with the hope of providing clues about the processes of nodule formation and growth. Specific objectives were to determine microbe-mineral interactions on and within nodules and the extent to which these influence nodule formation and growth and to use isotopic analyses to measure nodule growth rates. We further hope to distinguish microbial diversity specifically associated with Mn nodules, whether they provide a growth substrate or are themselves indicative of microbial activity (i.e., $\mathrm{Mn}$ oxidation). If the microbial community has a role in mediating the formation of Mn nodules, we hope to identify which organisms are responsible for the process using FISH and DNA analysis.

\section{Objectives of basalt studies}

At sites where we recovered the basaltic basement that underlies the sediment, we took samples for DNA analysis and microscopy of the basaltic glass to characterize its microbial communities for comparison to seafloor basaltic communities at other locations and look for differences based upon age and nutrient availability. These studies place a special focus on microbes involved in the iron and nitrogen cycles. To understand the potential isolation and connectedness of microbial communities in the basaltic basement to that in the overlying sediment, samples were taken to compare the bottommost recovered sediment microbial communities to communities in the basaltic glass recovered.

\section{Objectives of water column studies}

The South Pacific Gyre is the most oligotrophic region of Earth's oceans. Our concentration/tempera- 
ture/depth recorder (CTD) water column analyses and sampling focused on

1. Documenting key properties of the near-surface waters,

2. Sampling to determine bacterial diversity, and

3. Documenting the nature of the biological nitrogen cycle (nitrogen fixation rates, assimilation rates of organic and inorganic nitrogen, diazotrophic bacterial groups present, and the activity of nifH genes, which are responsible for nitrogen fixation) in this little-studied oceanic region (Halm et al., submitted).

\section{Protocols}

\section{Geophysical protocols (Pockalny, Abrams, Ellett, Harris, Murphy)}

\section{Geophysical mapping protocols (Pockalny, Abrams)}

Underway geophysical data collected during transits between core sites and during MCS acquisition at each site included the following:

- SIMRAD EM120 swathmap bathymetry,

- Knudsen digitally recorded $3.5 \mathrm{kHz}$ seismic reflection,

- Sea SPY Overhauser total field magnetics and gradiometry, and

- BGM-3 gravimetry.

SIMRAD EM120 swath mapping bathymetry was used for real-time assessment of potential coring targets during seismic surveys. The typical approach for a seismic survey was to orient the initial survey line oblique to the regional fabric so that the outer beams of the swath mapping system could be used to "forecast" promising sediment basins or avoid seamount chains. During this initial line, we determined the regional trend of abyssal hill fabric and used this trend as our heading for the crossing seismic line. The swath bathymetry data were also used in conjunction with the $3.5 \mathrm{kHz}$ seismic system to confirm whether a reflector in the seismic record was from the subsurface or an artefact from a side-echo. Additional processing of the SIMRAD EM120 with MB system software was required to "edit" bad pings and create gridded bathymetry data for analysis. This process included using the following:

1. MBedit (to remove individual bad pings),

2. MBprocess (to incorporate edits),

3. MBinfo (to create header files),

4. MBdatalist (to create list of data to be used),

5. MBgrid (to create bathymetry grid of survey area), and
6. Station_scripts (to enact generic mapping tool utilities to create postscript plot).

Knudsen $3.5 \mathrm{kHz}$ seismic reflection data were also used in real time for coring target assessment. The on-screen display was continuously monitored during the survey to determine variation in sediment thickness and reflection characteristics.

Sea SPY Overhauser total field magnetics data were used primarily during transits to identify the various magnetic anomalies traversed between coring stations. A C-Shell script (rr2mgd.csh) was written to calculate the anomalous magnetic field and merge the results with center-beam bathymetry and navigation data to create MGD77- and generic mapping tool-formatted files. The generic mapping tool-format file was then used as input into various generic mapping tool scripts for wiggle plots and forward modeling of the anomalous magnetic field data.

The BGM-3 gravimeter data were recorded; however, the digital output was not consistent with either free-air anomaly or total gravity field data. Additional processing by Scripps University will be required to incorporate these data into the research program.

\section{Seismic protocols (Abrams, Pockalny, Ellett, Murphy)}

Knudsen $3.5 \mathrm{kHz}$ seismic reflection data were recorded digitally and as an EPC paper record at 75 lines per inch. Recording depth range was generally set at $1000 \mathrm{~m}$ during transits and $500 \mathrm{~m}$ during site surveys. The $3.5 \mathrm{kHz}$ was set for a $24 \mathrm{~ms}$ chirp, power of 3 , and processing gain of 2 . Data were digitally recorded in SEGY format and proprietary Knudson format (keb). Navigation data for each $3.5 \mathrm{kHz}$ trace were also digitally recorded. The following file name conventions were used for $3.5 \mathrm{kHz}$ data:

- Transit data files: year_JD_hrmin_LF_line\#.sgy (e.g., 2006_354_1236_LF_001.sgy), containing 50,000 pings per file.

- Site data files: site\#_daymonthyr_line\# (e.g., site1_24dec06_001).

Approximately $8 \mathrm{~km}$ of $3.5 \mathrm{kHz}$ seismic data from each line crossing a site were digitally processed and displayed with the following parameters:

- Bandpass filter at 2800-3000-4000-4500 Hz.

- Constant gain or automatic gain control (100 ms operator window).

- 25 traces/inch horizontal, every second trace.

- 15 inches/s vertical.

MCS data were acquired at each site using one or two 150 inch $^{3}$ GI guns (45 inch ${ }^{3}$ generator chamber, 105 inch $^{3}$ injector) with a 48-channel digital streamer. 
Site survey data were acquired at $6 \mathrm{kt}$ except at Site SPG-12 (IODP Site U1371), when weather conditions required surveying at $4.5 \mathrm{kt}$. The MCS acquisition geometry is shown in the figures for each individual site description (see KNOXRPTS in "Supplementary material"). Data were digitally recorded in SEGD format and converted to SEGY format with the following parameters:

- $1 \mathrm{~ms}$ sample interval.

- $12 \mathrm{~s} / \mathrm{shot}(37 \mathrm{~m} / \mathrm{shot}$ at $6 \mathrm{kt})$.

- $0-8$ s recording window (0-9 s at Site SPG-1 [IODP Site U1365]).

The following file name convention was used for MCS data:

- Site data files: site\#_daymonthyr_line\# (e.g., site1_24dec06_001).

Approximately $13 \mathrm{~km}$ of MCS data from each line crossing a site were digitally processed and displayed with the following parameters:

- Convert SEGD to SEGY.

- Far channel gather (i.e., channel 48).

- Bandpass filter at 10-35-300-325 Hz.

- True amplitude, constant gain.

- 40 traces/inch horizontal.

- 11 inches/s vertical.

\section{Thermal gradient measurements (Harris)}

Thermal gradients were measured at most coring sites through the use of autonomous thermistor probes attached to the outside of the core barrel (Table T1). The autonomous data loggers are $175 \mathrm{~mm}$ in length and have a nominal temperature measurement range of $-5^{\circ}-60^{\circ} \mathrm{C}$, with higher sensitivities at lower temperatures. Instrument precision is $1 \mathrm{mK}$, and the absolute accuracy is several milli-Kelvin based on laboratory calibrations. The time constant of the thermistor is $\sim 2 \mathrm{~s}$. Nonvolatile memory can hold up to $18 \mathrm{~h}$ of measurements collected at a sample rate of $1 \mathrm{~s}$ or data from a longer period recorded at a lower frequency.

The data loggers were mounted to the outside of the core barrel using a finlike attachment. Two styles were used (Figs. F3, F4), a short fin and a longer fin that approximates an older style of outrigger thermistor probes. The fins were attached to the core barrel using banding in a spiral arrangement so that each logger would penetrate through relatively undisturbed sediment. The position of each fin was measured before and after deployment to determine the relative distance between thermistors and to ensure that the fins did not move during coring operations. A layer of rubber matting was placed between the attachments and the core barrel to increase the friction between the fin and core barrel. No movement during core operations on any of the fin attachments was observed. A logger for monitoring bottom water temperature and tilt was mounted inside the core weight. Measured tilts were small in all deployments in which the core did not fall over. When thermistors were attached to the core barrel, the core was left at bottom for $\sim 7 \mathrm{~min}$ to record a time series of temperatures so that equilibrium temperatures could be estimated.

A recurring concern during the cruise was the pullout tension in general and the added resistance that the attachments had on pullout. In general, thermistors were attached to $20 \mathrm{ft}$ piston cores or the second $30 \mathrm{ft}$ piston core when there appeared to be enough room so as not to exceed a maximum pullout tension of $20,000 \mathrm{lb}$. With the exception of the first site, where pullout was at a rate of $8 \mathrm{~m} / \mathrm{min}$, it appears that the thermistor attachments only added $\sim 600 \mathrm{lb}$ to pullout tension relative to cores in which the thermistors were not attached (Table T2). In most cases, four thermistors were mounted on the core barrel in two long-style and two short-style attachments.

At coring Site SPG-1, the loggers were set to record for a $5 \mathrm{~h}$ duration at a $1 \mathrm{~s}$ interval. Shipboard attempts to read the data were unsuccessful. The manufacturer was contacted, but repeated attempts to download the data were unsuccessful. These loggers were set aside and were read after the cruise. Additionally, at this site, a data logger and long-style fin were lost during recovery. All subsequent loggers used a duration of $5 \mathrm{~h}$ at a $5 \mathrm{~s}$ interval, and data recovery was successful.

\section{Thermal conductivity measurements (Harris)}

Thermal conductivities were measured using the needle-probe technique (laboratory code THERM). The values were collected from equipment borrowed from University of California Santa Cruz. Needle probes were calibrated against a gelatin standard. Consistent offsets were found between probes and adjusted based on the standard to account for the offsets, greatly improving the consistency of the results.

\section{Heat flow determinations (Harris)}

If thermal conductivity is constant, heat flow can be calculated as the product of the thermal gradient and thermal conductivity. 


\section{Core labeling protocols (Ferdelman, Anderson, Steinman)}

We employed the following scheme for labeling cores, lander samples, and samples from discrete intervals within the various types of cores.

Our general labeling scheme included the following information, in the following order:

1. Station.

2. Tool deployed + deployment number.

3. Section depth in section $(\mathrm{cm})$.

Stations are identified by site location (SPG1, SPG2, SPG12, etc.). No samples were taken for Station SPG8 because it was not included in the final ship track.

The coring tools deployed are identified by the following designations:

$\mathrm{P}=$ piston corer.

$\mathrm{J}$ = jumbo gravity corer (also known as "Big Bertha").

$\mathrm{T}=$ trigger corer to piston corer.

$\mathrm{TG}=$ trigger core run independently of a piston core (as a gravity corer).

$\mathrm{G}=$ gravity corer.

$\mathrm{M}=$ multicorer.

$\mathrm{L}=$ lander.

A deployment number $(1,2,3$, etc.) is assigned for each trip down and back for each tool at each site, whether sediment was recovered or not. Because of the limited number of deployments, this number was usually 1 or 2 for each tool at each site.

Section numbers (Sec1, Sec2, Sec3, Sec4, etc.) for the gravity trigger and piston corers represent core sections of $1.5 \mathrm{~m}$ or less and are numbered from the top.

For the multicorer, the section numbers refer to tube numbers.

For example:,

- SPG2-P2-Sec2 10-12 cm: this sample comes from the second deployment of the piston core at station SPG-2 (SPG2-P2-). The sample comes from the $10-12 \mathrm{~cm}$ depth horizon, measured from the top of the second section (Sec2) of the core. This code does not necessarily indicate the actual depth below surface but is an independent identifier. A corrected code/depth scale has to be worked out in order to precisely indicate the depth from which depth this core came.

- SPG5-M1-04 14-15 cm: this sample comes from the first deployment of the multicorer at station SPG-5. The sample comes from a depth of 14-15 $\mathrm{cm}$ from multicore tube 4 .

\section{Labeling work and archive halves}

The piston cores, trigger cores, and gravity cores that were cut for visual description, sampling, and archiving were labeled in the following manner.

The cores are ultimately destined to be split perpendicular to the P-Mag line. Therefore, each section half of the core liner was labeled (i.e., two times per section) prior to its placement in the coring device to indicate the working and archive halves of the cores. Prior to deployment, the sections were lettered with small Roman numerals starting from the bottom and going up to the top of the core (Fig. F5). This kept the order of sections clear until we established where the top of the sediment is, and therefore, the top of Section 1. Archive halves received the designation " $\mathrm{A}$ " and working halves received the designation "W."

After corer deployment and recovery, the core liners were removed from the core pipe and permanent section numbers were assigned in normal order from top (1) to bottom $(2,3$, etc.) as appropriate.

The core caps are color coded, with blue indicating the top of the core or section and red indicating the bottom. Station number, tool and deployment number, and section were labeled on each of the archive and working halves of the top and bottom core caps.

\section{Core cutting protocols (Ferdelman, Anderson, Steinman)}

\section{Piston and trigger gravity cores}

At each site, two piston or relatively long gravity cores were usually obtained. These cores were designated either for microbiological/interstitial water analysis (MBIO/IW) or for oxygen measurements and sedimentological studies. Cores meant for $\mathrm{MBIO} / \mathrm{IW}$ sectioning were moved as quickly as possible to the scientific cold room until they could be sectioned and subsampled. Individual sections were cut into whole-round intervals at predefined depths for interstitial water sampling and microbiological subsampling. Remaining subsections of the core were labeled "MST" (for multisensor track) and set aside for sedimentological and physical properties measurements. From the working halves of the MST intervals, additional samples were taken for headspace and high-resolution cell counting purposes. The MST intervals were then forwarded to the MST van for physical properties measurements. The remainders of the MBIO intervals were placed in the refrigerated container at $5^{\circ} \mathrm{C}$. Sample codes for subsamples are given in Table T3.

The sections of cores that were designated for oxygen measurements $\left(\mathrm{O}_{2}\right)$, thermal conductivity (THERM), and sedimentological analysis were placed 
in the main laboratory to achieve temperature equilibration with the laboratory. After temperature equilibration, dissolved oxygen concentration was measured at $20-30 \mathrm{~cm}$ intervals in each core section (see below for optode and electrode oxygen determinations). After the oxygen measurements, thermal conductivity measurements were performed. On a small number of these cores, pore waters were also subsampled using Rhizon samplers (RHIZ).

\section{Multicores}

Multicores were removed immediately to the scientific cold room. Subsampling generally followed the scheme listed in Table T4. This table provides a general scheme for sample distribution. Sampling combinations were often changed due to recovery of fewer than eight intact multicores or other reasons. Water overlying the sediments in the multicores (OW) was often subsampled. Starting with Site SPG9 , the multicore designated for interstitial water sampling was processed immediately on the deck. This accelerated delivery of the samples to the Chemistry Laboratory for squeezing and processing. The lithology and physical properties (LPP) cores were also sampled outside.

\section{Core-logging protocols (Rogers)}

Every core retrieved during Cruise KNOX-02RR was run through Oregon State University's GEOTEK multisensor core logger. The core track was set up for up to $1.5 \mathrm{~m}$ sections of 4 inch $(\sim 0 \mathrm{~cm})$ polyvinyl chloride (PVC) core liner and had instruments to measure gamma ray attenuation, core thickness deviation, $P$-wave traveltime, temperature, and magnetic susceptibility.

Gamma ray attenuation was measured using a directed ${ }^{137} \mathrm{C}$ source and detector. This pair of instruments was mounted horizontally such that any gaps caused by slumping should end up at the top. The raw data are in counts per second (cps). Typical maximum counts were around 20,000 cps, whereas a typical core section was near 8,000 cps. Variations in these attenuated gamma counts are related to changes in core density or thickness.

The velocity of sound, or $P$-wave velocity, was measured by two rollers kept in contact with the core liner. This measurement is dependent on a good connection by both rollers and accurate measurement of core thickness. Calipers attached to these rollers measure deviation in millimeters from a calibration piece.

Magnetic susceptibility was measured with a loop sensor just large enough to fit the core through. Sen- sitive circuits measure the strength of the magnetic field supported by minerals in the core. Any proximity of metal interferes with this instrument, and the edge effects of this measurement are significant. The temperature of the core and the temperature of the instrument also affect the magnetic measurement.

A thermal probe was inserted at the bottom of the last section of each core. The HVAC system in the van attempted to keep a constant temperature of $21^{\circ} \mathrm{C}\left(69^{\circ}-71^{\circ} \mathrm{F}\right)$ to minimize variations in temperature.

A number of calibrations were made to the instrument and software prior to collecting data. The temperature probe was calibrated against water of different temperatures measured with a thermometer from another laboratory. Oregon State University provided a 4 inch core section with solid aluminum cylinders of different diameters and freshwater. With the gamma attenuation of this calibration piece and the known densities of water and aluminum, the density of other cores of the same size should be accurately measured. This standard was rerun every few stations, as the gamma detector changes with time. In addition to these calibrations, a deionized water standard constructed using a section of our liner was run before every core as a basis for future comparison and postprocessing.

A number of different types of cores were logged on this track. Trigger cores, large gravity cores, and piston cores were in 4 inch PVC liners with a $0.61 \mathrm{~cm}$ wall thickness, and small gravity cores were in 2.5 inch clear plastic liners.

Each core was split into sections of $1.5 \mathrm{~m}$ or less, with most sections being $1.5 \mathrm{~m}$ and the topmost section being of various shorter lengths, depending on recovery. Typically, many whole-round samples were removed from the first piston core for biogeochemical and microbiological sampling purposes. For logging, the remaining pieces of the core were spaced with empty core liner to reconstruct the length and spacing of the original core in the logger. Because of rounding errors and end cap thickness, these reconstructions are accurate only to a couple of centimeters.

The multisensor track was not set up for the smaller 2.5 inch gravity cores. To log these cores, a half-section of 4 inch liner was placed on the track and lined with bubble wrap to reduce the density error. The 2.5 inch core was placed on this plastic spacer such that its thickest point was in line with the gamma pathway. The only three measurements valid for this method are raw gamma data, temperature, and magnetic susceptibility. Proper logging of these cores would require changing to a different track setup ev- 
ery station and, consequently, would be impractical for underway work.

\section{Sedimentology protocols (Hasiuk, Stancin)}

Material for sedimentological analysis came as either as whole-core material (in PVC liners) from the MST van or as miscellaneous samples from various points in the core stream. Whole-core sections were split for description using a jig-mounted circular saw and delivered to the shipboard sedimentology station for description and analysis.

To aid with core description, plastic buttons were inserted into the core every $10 \mathrm{~cm}$ from top of section and were labeled every $50 \mathrm{~cm}$, with a minimum of one labeled button per section. The basic record of core descriptions is the paper log sheet, which contains identification, location, date of description, and all descriptive and sampling information. A smear slide was made at least once per section (more often if interest arose). It was analyzed under both reflected light and polarized light microscope at magnifications between $1 \times$ and 100x. Bulk sediment and relevant sedimentary features were colormatched to Munsell soil color charts.

Samples for sediment porosity determination were taken in close proximity to interstitial water samples and where oxygen measurements were made. Porosity samples were adjacent to interstitial water samples when possible or at regular intervals in whole cores (generally 10, 40, 70, 100, and $130 \mathrm{~cm}$ ).

Samples were collected for elemental and isotopic carbonate geochemistry at Sites SPG-5 and SPG-6 (IODP Site U1368) (25 cm interval) and at Site SPG-7 (10 cm interval). At Sites SPG-9 and SPG-10 (IODP Site U1369), samples were collected every $25 \mathrm{~cm}$ for determination of mineralogy postcruise using X-ray diffraction (XRD).

For postcruise studies of the sediment's radiolytic potential, $\sim 50 \mathrm{~g}$ of wet sediment was taken from the leftovers of the MBIO sections from Site SPG-3 for high-resolution gamma spectroscopy (GAMMA) at MPI.

Subsequent to sampling, cores were plastic wrapped and sealed at both ends (and in the middle of full 1.5 $\mathrm{m}$ sections) with masking tape and placed in Dtubes, which were labeled with site, coring device, section, interval, up arrow, and archive/working designation. D-tubes were then boxed and stored in a refrigerated cargo container for shipment to the URI core repository.

\section{Conductivity protocols \\ (Hasiuk, Stancin)}

Conductivity measurements were made to supplement interstitial water chemistry. They were performed every $5 \mathrm{~cm}$ on cores where interstitial water samples were taken, as well as on some other whole cores to produce longer uninterrupted data sets.

A Brinkmann/Metrohm conductometer was used for the procedure. For calibration, standards were made from $100 \%$ seawater; $75 \%$ seawater and 25\% $18 \mathrm{M} \Omega$ deionized water; $50 \%$ seawater and $50 \%$ deionized water; $25 \%$ seawater and $75 \%$ deionized water; and $100 \%$ deionized water. These standard solutions were analyzed at the beginning of each section of core. Generally this calibration yielded a linear relationship with a correlation coefficient $>0.95$. If this metric fell below 0.95, the standard solutions were remade. If the correlation coefficient was $<<0.95$, the probe was replatinized.

The probe consisted of two metal prongs $1 \mathrm{~cm}$ apart set in a plastic block. The probes were inserted into the sediment until the block rested on the sediment surface. The prongs were aligned parallel to the depth axis of the core to measure vertical conductivity. The probe was cleaned with deionized water between uses.

Every five measurements, the $100 \%$ seawater standard solution was analyzed to provide a measurement of instrument drift. However, sediments analyzed varied little downcore, with the exception of Site SPG-5, where a change in lithology from clay to carbonate gave a large change. Poor data were generated when analyzing excessively liquid sediment (such as at the top of the first section of cores), air pockets (often created by sampling), or edge material.

\section{Biogeochemistry protocols (Spivack, Fischer, Fuldauer, Graham, Griffith, Nordhausen, Schrum, Smith) \\ Interstitial water analyses (Spivack, Fuldauer, Graham, Griffith, Schrum)}

Interstitial water samples were recovered from $5 \mathrm{~cm}$ long whole rounds sliced from cores and with Rhizon samplers. Water was extracted from the whole rounds using a Manheim-type squeezer. Depending on the length of the recovered core, sampling intervals were varied to maximize the number of interstitial water samples and still leave sufficient core for microbiological sampling between interstitial water samples (12-27 cm, depending on core length). This 
sampling strategy was designed to produce high-resolution chemical profiles suitable for inferring rates of metabolic reactions.

The collected interstitial water was split into aliquots for the various shipboard and postcruise chemical analyses. Shipboard analyses included alkalinity titrations; methane quantification by gas chromatography; and sulfate, chloride, bromide, and nitrate determinations by ion chromatography.

Alkalinity titrations were run on a Metrohm 809 Titrando autotitrator with a Metrohm $\mathrm{pH}$ microelectrode. An aliquot of $3 \mathrm{~mL}$ of interstitial water was titrated with $0.1 \mathrm{M} \mathrm{HCl}$ at $25^{\circ} \mathrm{C}$. Alkalinity was calculated with the Gran determination:

$$
\mathrm{F}=\left(V_{\mathrm{a}}+V_{\mathrm{o}}\right) \times 10^{E / A},
$$

where

$\mathrm{F}=$ Gran factor,

$V_{\mathrm{a}}=$ volume of acid added to the sample $(\mathrm{mL})$,

$V_{\mathrm{o}}=$ original volume of the sample $(\mathrm{mL})$,

$E$ = electromotive force $(\mathrm{mV})$, and

$A$ = slope of electrode determined by an electrode calibration.

Alkalinity (in $\mathrm{mM}$ ) is equal to the $y$-intercept divided by the slope of the $\mathrm{F}$ versus $V_{\mathrm{a}}$ plot times 33.33 (Gieskes et al., 1991). The electrode was calibrated with three $\mathrm{pH}$ standards. The $A$ value was determined from the slope of an $E$ versus $\left(V_{\mathrm{a}} \times N_{\mathrm{a}}\right) /\left(V_{\mathrm{a}}+\right.$ $V_{\mathrm{o}}$ ) plot, where $N_{\mathrm{a}}$ is the normality of the titrant. An International Association for the Physical Sciences of the Oceans (IAPSO) seawater standard was analyzed at the beginning and end of a set of samples for each station. Surface seawater was analyzed after every fourth sample to measure precision.

For methane analyses, two $5 \mathrm{~cm}^{3}$ sediment plugs were collected in $20 \mathrm{~mL}$ headspace vials and sealed with Teflon/silicon septa and crimp caps. One set of samples was treated with $2 \mathrm{~mL}$ of $1 \mathrm{M}$ sodium hydroxide, flushed with $\mathrm{He}$ for $30 \mathrm{~s}$, inverted, and stored for future analysis. The other set of samples was flushed with He and run on a Shimadzu GC-17A gas chromatograph. The sample was injected as soon after He flushing as possible and injected again after being heated to $70^{\circ} \mathrm{C}$ for a minimum of $30 \mathrm{~min}$. The gas chromatograph was equipped with a $1 \mathrm{~mL}$ sample loop coupled to a $2.5 \mathrm{~m} 80 / 100$ mesh Hayesep R packed column and flame ionization detector. The gas chromatograph was calibrated using $\mathrm{He}$ as the zero point, ambient laboratory air as 2 ppm methane, and a certified 5 ppm methane gas standard.

Sulfate, chloride, and bromide were quantified with a Metrohm 861 Advanced Compact ion chromatograph. The ion chromatograph was comprised of an
$853 \mathrm{CO}_{2}$ suppressor, a thermal conductivity detector, a $150 \mathrm{~mm} \times 4.0 \mathrm{~mm}$ Metrosep A SUPP 5150 column, and a $20 \mu \mathrm{L}$ sample loop. A Metrohm 837 ion chromatography eluent/sample degasser was coupled to the system. The column oven was set at $25^{\circ} \mathrm{C}$. The eluent solution was $3.2 \mathrm{mM} \mathrm{Na} \mathrm{CO}_{3}, 1.0 \mathrm{mM}$ $\mathrm{NaHCO}_{3}$. A 1:50 dilution of interstitial water and 18 $\mathrm{M} \Omega$ deionized water was analyzed. Interstitial water, blanks (18 $\mathrm{M} \Omega$ deionized water), a 1:50 dilution of filtered surface seawater, and standards (a 1:50 dilution of IAPSO seawater standard) were loaded on a Metrohm 813 compact autosampler. Duplicates of interstitial water were analyzed consecutively, and each sequence was run twice. A standard was run after every fourth interstitial water sample. The surface seawater was run in duplicate at the beginning and end of the sequence to measure precision within and between the sequences.

Nitrate concentrations were analyzed with a Metrohm $844 \mathrm{UV} / \mathrm{Vis}$ compact ion chromatograph. A $150 \mathrm{~mm} \times 4.0 \mathrm{~mm}$ Metrosep A SUPP 8150 column was used. The column oven was set at $30^{\circ} \mathrm{C}$. The eluent was a $10 \% \mathrm{NaCl}$ solution. An aliquot of $0.75 \mathrm{~mL}$ of interstitial water was injected manually into a 250 $\mu \mathrm{L}$ sample loop. The sample and eluent were measured spectroscopically with an ultraviolet lamp as the light source. Wavelengths of 210 and $215 \mathrm{~nm}$ were used. Duplicates were run on each sample. A standard made up of $35.72 \mu \mathrm{M} \mathrm{NO} \mathrm{N}_{3}$ in surface seawater was run after every fourth sample. Seawater spiked with $35 \mu \mathrm{M} \mathrm{NO}_{3}$ was analyzed at the beginning and end of each sequence to measure precision.

Samples were collected for postcruise determination of concentrations of diverse dissolved chemicals $\left(\mathrm{Ca}^{2+}, \mathrm{Mg}^{2+}, \mathrm{K}^{+}, \mathrm{Na}^{+}, \mathrm{NH}_{4}{ }^{+}\right.$, dissolved organic carbon [DOC], dissolved organic nitrogen, carbohydrate, dissolved amino acids, fatty acids, dissolved inorganic carbon [DIC], $\mathrm{He}, \mathrm{Fe}^{2+}, \mathrm{Mn}^{2+}$, and $\mathrm{PO}_{4}$ ), as well as for determination of $\delta^{15} \mathrm{~N}$ of dissolved $\mathrm{NO}_{3}{ }^{-}$and/ or $\mathrm{NH}_{4}{ }^{+}$and $\delta^{13} \mathrm{C}$ of DOC/DIC. Squeezed sediment was retained for postcruise determination of uranium, thorium, and potassium concentrations, total organic carbon, carbonate, $\delta^{13} \mathrm{C}$ of bulk organic matter, and mineralogy. Chemical treatments for postcruise analyses are tabulated in Table T5.

\section{Oxygen analysis (Fischer, Nordhausen)}

Ex situ dissolved oxygen measurements were performed on sections of cores (Fischer et al., 2009). Except at Site SPG-3, these measurements were performed on complete core sections, which were typically $150 \mathrm{~cm}$ long, with the top and bottom sections usually shorter. Because only one piston core was successfully recovered at Site SPG-3, the oxygen 
measurements were done on the sections sampled for interstitial water analysis and microbiology; the subsections that remained for oxygen measurements were $\sim 30 \mathrm{~cm}$ long. At Sites SPG-11 (IODP Site U1370) and SPG-12, large gravity cores were used. Prior to the measurements, cores were placed for at least $12 \mathrm{~h}$ at $20^{\circ} \mathrm{C}$ in the air-conditioned main laboratory with the closest air exchange vents blocked to ensure thermal equilibration. Holes were then drilled every $30 \mathrm{~cm}$, and the concentration of dissolved oxygen was determined by inserting a probe radially into the center of the core. Model calculations and radial profiles showed that the oxygen concentration in the center of the core was not affected by ambient air on these timescales.

At Sites SPG-1 and SPG-2 (IODP Site U1366), both custom-made Clark-type microelectrodes (Revsbech and Jørgensen, 1986) and optodes (Klimant et al., 1995) were used to evaluate which method is better suited for application to whole-round cores. The oxygen optodes, connected to a Microsensor Oxygen Meter Microx TX3 (Presens GmbH, Regensburg, Germany), turned out to be more stable and were used for all other measurements.

For the in situ measurements, a free-falling benthic lander was used. Once released, the lander sinks to the sediment surface and starts the measurements autonomously. After finishing the measurements, the lander releases weights and rises back to the surface. This can be triggered by an acoustic signal or by a burn wire timer. The lander was equipped with an array of four custom-made optodes, mounted on stainless steel tubes (6 $\mathrm{mm}$ diameter), which could profile $45 \mathrm{~cm}$ into the sediment. A microprofiler that held four oxygen microelectrodes was used to determine the oxygen profile in the uppermost 20-50 $\mathrm{mm}$ of the sediment, as well as the diffusive oxygen uptake. To measure the total oxygen uptake directly, an incubation chamber with two optodes and a syringe sampler was used. In addition, a Niskin bottle for bottom water samples was attached to the lander.

\section{Hydrogen analysis (Smith, Spivack)}

The concentration of hydrogen gas $\left(\mathrm{H}_{2}\right)$ dissolved in the interstitial water was measured at each site. This was done by placing $\sim 3 \mathrm{~cm}^{3}$ of sediment into a vial and filling the vial completely with deionized water, taking care to not include any headspace. Hydrogenfree gas $(500 \mu \mathrm{L})$ was then injected through the septum while allowing an equal volume of water to escape to create a headspace. The $\mathrm{H}_{2}$ was then given time to diffuse out of the interstitial water $(>24 \mathrm{~h})$.
After allowing the $\mathrm{H}_{2}$ to accumulate in the headspace, $300 \mu \mathrm{L}$ was removed and injected into a reduced gas analyzer (Trace Analytic ta3000). The instrument was calibrated with a $100.6 \mathrm{ppm} \mathrm{H}_{2}$ standard (Scott Specialty Gases). Blanks were prepared by using vials with deionized water and the $\mathrm{H}_{2}$-free headspace. In this configuration, the system had an average detection limit of $67 \mathrm{nM} \mathrm{H}_{2}$ with a range of 2-229 $\mathrm{nM}$.

At Site SPG-1, $3 \mathrm{~cm}^{3}$ plugs of sediment were placed in glass vials, filled with deionized water and $\mathrm{a} \sim 1 \mathrm{~cm}^{3}$ headspace consisting of laboratory air. The blanks using laboratory air contained too much $\mathrm{H}_{2}$ relative to the samples and severely increased the detection limit. Beginning with Site SPG-2, the procedure was modified to use bypass gas (carrier gas $\left[\mathrm{N}_{2}\right]$ that had passed over the mercury bed to remove traces of $\mathrm{H}_{2}$ ) for the headspace.

For these analyses, samples were collected at each site either directly above or below each whole-round sample taken for geochemical analysis. The samples were taken from the core in $3 \mathrm{~cm}^{3}$ cut-off syringes and extruded directly into the vial and immediately filled with water and capped.

\section{Microbial activity protocols (Ferdelman, Soffientino)}

\section{Protocol for tritiated $\mathrm{H}_{2}$ assay of hydrogenase activity (Soffientino)}

Measurement of hydrogenase activity is carried out using the tritium-based method of Soffientino et al. (2006). Briefly, $3 \mathrm{~cm}^{3}$ of sediment was slurried with $10 \mathrm{~mL}$ sterile filtered seawater in a $30 \mathrm{~cm}^{3}$ glass syringe. A headspace of tritiated hydrogen and nitrogen was added, and the samples were incubated at ambient temperature $\left(20^{\circ} \mathrm{C}\right)$ with gentle shaking for $12 \mathrm{~h}$. Subsamples of the slurry were withdrawn every hour, degassed, and scintillation counted. Four samples per core were assayed in triplicate, with paired killed controls made by slurrying sediment with saturated mercuric chloride solution instead of seawater. The hydrogenase activity is calculated as the linear slope obtained by regression of the scintillation counts against time. The detection limit of the assay is between $1 \times 10^{-12}$ and $1 \times 10^{-13} \mathrm{~mol}$ hydrogen $/ \mathrm{cm}^{3}$ sediment $/ \mathrm{min}$.

\section{Protocols for other microbial activities (Ferdelman)}

\section{Slurry preparation}

A $60 \mathrm{~cm}^{3}$ subcore is taken from the piston or multicorer core and extruded into aluminium-polyethyl- 
ene "wine-bag." A total of $60 \mathrm{~mL}$ of filtered overlying water is added to the sediment, and the sediment water mixture is slurried. At the surface, these volumes are doubled. From this slurry we took the following:

- Three $60 \mathrm{~cm}^{3}$ syringes each containing $20 \mathrm{~cm}^{3}$ for cysteine degradation experiments (CYS; only at surface).

- One $6 \mathrm{~cm}^{3}$ syringe containing $6 \mathrm{~cm}^{3}$ for thymidine uptake (THY).

- Five $6 \mathrm{~cm}^{3}$ in $6 \mathrm{~mL}$ Exetainers for ${ }^{15} \mathrm{~N}-\mathrm{NH}_{4}{ }^{+}$experiments (AM).

- Five $6 \mathrm{~cm}^{3}$ in $6 \mathrm{~mL}$ Exetainers for ${ }^{15} \mathrm{~N}-\mathrm{NO}_{3}{ }^{-}$experiments (NO).

The remaining slurry was frozen at $-20^{\circ} \mathrm{C}$.

\section{Nitrate and ammonium experiments}

1. Prepare and label $6 \mathrm{~mL}$ volume Exetainers for t0, t1...t4.

2. Add $10 \mu \mathrm{L}$ of $100 \mathrm{mM}$ of ${ }^{15} \mathrm{~N}$-labeled ammonium or ${ }^{15} \mathrm{~N}$-labeled nitrate to each vial.

3. Add $100 \mu \mathrm{L}$ of saturated mercuric chloride solution to t0 vials.

4. Add slurry to top of each vial. Cap and incubate at $5^{\circ} \mathrm{C}$.

5. Stop experiments by adding $100 \mu \mathrm{L}$ of mercuric chloride.

6. Time points $1,2,3$, and 4 are set for $1,2,3$, and 4 days.

7. Samples were shipped to Bremen for analysis of the isotope ratio of nitrate (AM nitrification experiments) and dinitrogen gas (NO denitrification experiments).

\section{Thymidine experiment}

1. Prepare and label (t0, t1 ...t3) $2 \mathrm{~mL}$ cryovials each with $400 \mu \mathrm{L}$ formaldehyde/thymdine solution.

2. In Radioactivity Isolation Van, prepare a 2.46 $\mathrm{kBq} / \mu \mathrm{L}$ secondary stock solution by diluting 100 $\mu \mathrm{L}$ of $37 \mathrm{kBq} / \mu \mathrm{L}$ into $1400 \mu \mathrm{L}$ of deionized water.

3. Inject $100 \mu \mathrm{L}$ of this secondary stock solution into the $6 \mathrm{~mL}$ of sediment slurry prepared earlier. This gives $247 \mathrm{kBq}$ total radioactivity per syringe or $62 \mathrm{kBq}$ per experiment $(1.5 \mathrm{~mL})$.

4. Immediately add $1.5 \mathrm{~mL}$ of labeled slurry to the t 0 vial. Time points $t 1$ through $t 3$ are stopped on a daily basis.

5. Samples were sent to Bremen on dry ice for processing and scintillation counting.

\section{Cysteine degradation experiment}

1. Fill three $60 \mathrm{~cm}^{3}$ syringes each with $20 \mathrm{~cm}^{3}$ of slurry marked A, B, C.
2. Prepare three $2 \mathrm{~mL}$ Eppendorf vials with $1 \mathrm{~mL}$ of dissolved sodium cysteine at concentrations of (A) $3 \mathrm{nM}$, (B) $15 \mathrm{nM}$, and (C) $60 \mathrm{nM}$.

3. To each of the Eppendorf vials add $10 \mu \mathrm{L}$ of 18.5 $\mu \mathrm{Bq} / \mu \mathrm{L}{ }^{35}$ S-cysteine.

4. In Radioactivity Isolation Van, add the $1.1 \mathrm{~mL}$ of ${ }^{35} \mathrm{~S}$-cysteine/cysteine mixture to the respective slurries $\mathrm{A}, \mathrm{B}$, and $\mathrm{C}$ and mix well.

5. At times $0 \mathrm{~h}, 12 \mathrm{~h}, 1$ day, 1.5 days, and 2 days, inject $3 \mathrm{~mL}$ of slurry mixture into $6 \mathrm{~mL}$ of $20 \%$ (weight/vol) of zinc acetate solution and mix well.

6. Samples were sent to Bremen on dry ice for processing and determination of total reducible inorganic sulfur and scintillation counting.

\section{Microbiology protocols}

\section{(Smith, Durbin, Forschner, Harrison, Horn,} Kallmeyer, Lever, Puschell, Soffientino)

Sample handling protocols (Smith, Durbin, Forschner, Harrison, Horn, Kallmeyer, Lever, Puschell, Soffientino)

All microbiological sampling of the sediments was done with sterile cut-off syringes. These syringes were prepared in two ways. For the first two sites, syringes were cut by hand with either a knife blade or a small saw, wrapped in foil, and autoclaved. For subsequent sites, syringes were cut using a webcutter heated knife. Syringes of $3 \mathrm{~mL}$ volume were then modified by hand using a knife blade to angle the leading edge of the syringe inward. After cutting, the outside leading edge of larger syringes was run across the hot knife to give a clean edge that angled outward. Then the syringes were wrapped in foil and autoclaved with the plunger pulled back. The sampling surface of the sediment cores was scraped using a sterilized spatula and sampled at a distance of several millimeters from the edge of the core to avoid contamination. The filled syringes were recapped with foil and sealed either in foil bags or sterile bags and distributed for the various projects.

\section{Cell enumeration protocols (Kallmeyer, Puschell, Harrison)}

At all sites, sediment samples were taken for four different categories of cell enumeration:

1. SYBR Green counts of cells separated from the sedimentary matrix,

2. CARD-FISH counts of cells separated from the sedimentary matrix,

3. Acridine orange counts of cells in slurried sediment, and

4. CARD-FISH enumeration of cells in slurried sediment. 
Because cell concentrations were expected to be below the detection limit of standard acridine orange direct count techniques $\left(\sim 10^{5}\right.$ cells $\left./ \mathrm{cm}^{3}\right)$, shipboard efforts focused on cell counts using the first approach and on appropriate preparation of samples for the second, third, and fourth approaches.

For comparison to sedimentary cell counts, surface water samples were taken by bucket from the ship at each site and bottom water samples were taken from the water in the multicorer tube sampled for cell counts. The surface water samples were from approximately the upper $10 \mathrm{~cm}$ of the water column.

Shipboard separation of cells from the sedimentary matrix was achieved with a technique developed by Kallmeyer et al. (2008). The sediment is treated with a mixture of different detergents, solvents, and complexing agents, followed by separation of the cells from the sediment particles by density centrifugation. The cell extracts are then filtered and stained with SYBR Green I, a stain with high specificity for double-stranded DNA. At each site, samples were taken for this purpose from a multicore and from the longest piston core or gravity core available. Depending on the length of the core, between 12 and 25 samples were taken at each site, evenly spaced over the entire depth range. Selected samples were immediately analyzed; the remainder were analyzed postexpedition. For each depth, one $2 \mathrm{~cm}^{3}$ sample was fixed in $8 \mathrm{~mL}$ of $2.5 \% \mathrm{NaCl}$ solution with $2 \%$ formalin as a fixative. From this slurry, three $500 \mu \mathrm{L}$ aliquots were extracted and counted as described above. At every site, one blank sample was processed by treating $500 \mu \mathrm{L}$ of $0.2 \mu \mathrm{m}$ filtered $\mathrm{NaCl}$ solution like a sediment sample throughout the entire extraction and counting procedure.

Sediment samples were also collected for postcruise microscopy at different depths throughout a multicore and the longest piston core or gravity core at each site. The sampling resolution for these samples was one sample every $5 \mathrm{~cm}$ in the multicore and roughly one sample every $0.5 \mathrm{~m}$ in the longer core. These microscopy samples were then processed with five different fixation methods. For each sample collected, $1 \mathrm{~cm}^{3}$ was used for acridine orange counts (fixed in $9 \mathrm{~mL}$ of $2 \%$ formaldehyde in artificial seawater and stored at $4^{\circ} \mathrm{C}$ ), $0.5 \mathrm{~cm}^{3}$ was used for CARDFISH (fixed in $1.5 \mathrm{~mL}$ of $5.3 \%$ formaldehyde in artificial seawater overnight, then washed two times with artificial seawater and stored in 50\% phosphate buffered saline $[\mathrm{PBS}] /$ ethanol buffer at $\left.-20^{\circ} \mathrm{C}\right), 0.5 \mathrm{~cm}^{3}$ was used for CARD-FISH with an alternative fixation technique (fixed in $1.5 \mathrm{~mL}$ of $70 \%$ ethanol for $4 \mathrm{~h}$ and then washed two times and stored in 50\% PBS/ ethanol buffer), and $1.0 \mathrm{~cm}^{3}$ was used for incubations of 2 and $48 \mathrm{~h}$ with BrDU followed by fixation with 5.3\% formaldehyde and washing steps and then storage in 50\% PBS/ethanol. The purpose of using several methods was to look for evidence of cell viability in the sediment. Because acridine orange stains nucleic acid, that method was used to count cells independently of the SYBR Green counts. Samples were stained with CARD-FISH to look for the activity of cells by detection of rRNA. The BrDU incubations will allow the detection of cells that are synthesizing DNA, an indicator for cell division. This is achieved by staining the cells with a BrDU-specific antibody and then doing a secondary stain with a fluorescent tagged antibody.

Additional $5 \mathrm{~cm}^{3}$ samples for postcruise microscopy were collected and fixed for $4-12 \mathrm{~h}$ with $1 \%$ formaldehyde, rinsed twice with 1:1 PBS/ethanol, and resuspended in $5 \mathrm{~mL}$ ethanol. These samples were divided into discrete mineral partitions on shore for additional CARD-FISH studies. Sediment plugs of 3 $\mathrm{cm}^{3}$ were collected at $1 \mathrm{~m}$ intervals and fixed as above for postcruise cell separation and filtration for FISH.

\section{Molecular protocols for sediments (Durbin, Forschner, Harrison, Lever, Puschell)}

Sediment samples, used to characterize microbial community composition and changes within sediment columns and between sites, were obtained from both piston and multicores (Durbin and Teske, 2010). Piston cores were sampled at regular depth intervals. Samples designated for molecular diversity characterization and genomics were sampled using two $60 \mathrm{~cm}^{3}$ syringes of sediments every $30-100 \mathrm{~cm}$ core interval. Both $60 \mathrm{~cm}^{3}$ syringes were aliquotted into $5 \mathrm{~cm}^{3}$ subsamples, some of which were frozen at $-80^{\circ} \mathrm{C}$ without further processing, whereas others were slurried in saline solution $(30 \mathrm{~g} / \mathrm{L} \mathrm{NaCl}, 60-240$ $\mathrm{mM} \mathrm{NaPh}$ ) or in $3.5 \%$ saline $/ 10 \%$ glycerol prior to freezing at $-80^{\circ} \mathrm{C}$.

Multicores for high-resolution microbial diversity and genomics studies in surface sediments were sampled continuously, from top to bottom. Sampling occurred with three $60 \mathrm{~cm}^{3}$ syringes, each of which had a depth scale on the side, which allowed high-resolution subsampling of sediment in $1 \mathrm{~cm}$ depth intervals. The top $20 \mathrm{~cm}$ was sectioned into $1 \mathrm{~cm}$ depth intervals, and each interval was pooled. Depending on multicore recovery, we subsampled sediments below similarly, but using $2 \mathrm{~cm}$ depth intervals from 20-30 centimeters below seafloor (cmbsf) and $5 \mathrm{~cm}$ intervals in sediments below $30 \mathrm{cmbsf}$. All subsamples obtained from multicores were immediately frozen at $-80^{\circ} \mathrm{C}$. 
To generate a distinct and reproducible pattern that can be used for comparing the biodiversity of surface sediments from different sites, sediment samples (60 $\mathrm{cm}^{3}$ ) for terminal restriction fragment length polymorphism (tRFLP) analysis were taken at selected sites from the top layer of the multicore and stored at $-80^{\circ} \mathrm{C}$. This analysis will be used to determine the microbial diversity by amplifying $16 \mathrm{~S}$ rRNA genes from the sediment and cutting them with restriction enzymes and sorting the fragments by size.

To assess the total bacterial diversity of the sedimentary communities in select horizons of all the sites, $60 \mathrm{~cm}^{3}$ samples were taken at regular intervals and frozen for postcruise $16 \mathrm{~S}$ tag sequencing.

To determine biosynthetic potential, a $60 \mathrm{~cm}^{3}$ sample was collected at $\sim 1 \mathrm{~m}$ intervals from the piston corer and a $10 \mathrm{~cm}^{3}$ sample was taken in $10 \mathrm{~cm}$ increments from the multicorer. Samples were preserved at $-80^{\circ} \mathrm{C}$ for shore-based molecular analysis of bacterial genes associated with polyketide and nonribosomal peptide synthesis. Because of the low biomass, DNA extractions will be subjected to whole genome amplification prior to PCR amplification for detection of the genes. Presence or absence of biosynthetic gene clusters will be put in context of depth and geochemical properties to help direct future culturing and sampling efforts.

To document microbe-mineral associations, plugs of sediment from piston and multicores were frozen at $-80^{\circ} \mathrm{C}$ for shore-based DNA extraction, after splitting the sediment into component minerals using magnetic separation followed by density separation in sodium metatungstate (a nontoxic heavy liquid adjustable up to $3.1 \mathrm{~g} / \mathrm{cm}^{3}$ ). For these studies, DNA will be extracted from bulk samples and mineral fractions for construction of clone libraries, 16s rRNA gene sequencing, and tRFLP. XRD and energy dispersive spectroscopy using a scanning electron microscope (SEM-EDS) will be performed on extracted samples to confirm compositional heterogeneity. Mn nodules have also been selectively sampled to be processed as stated above. Homogenized mineral samples were taken from stations 2,7 , and 9 to be processed for mineral separation, XRD, and SEM-EDS in order to better characterize sediment mineralogy and to extract micrometeorites.

\section{Cultivation protocols for sediments (Puschell, Forschner)}

For our basic cultivation studies, $20 \mathrm{~cm}^{3}$ sediment samples were taken at different depths throughout a multicore and a piston core at each site. The sample resolution obtained for the multicore was one sample every $5 \mathrm{~cm}$. For the piston core three samples were taken from different depths depending on the length of the core. Also, at sites where the piston core retrieved the basalt/sediment interface, a cultivation sample of $10 \mathrm{~cm}^{3}$ was taken from the lowermost sediment. The total number of cultivation samples per site was between 7 and 10. The number of samples taken was much greater than could be processed during the cruise. Inoculations of aerobic cultures were done at all sites with the top layer of sediment sampled from the multicore. At selected sites, aerobic cultures were also started at multiple depths within the multicore. Seven types of media were used for aerobic enrichments. These were designed to target ammonium oxidizers, manganese oxidizers, thiosulfate oxidizers, nitrite oxidizers, nitrogen fixers, heterotrophs adapted for oligotrophy, and methyltrophs. Inoculations of anaerobic cultures were done using the top layer of sediment from the multicore and the deepest sediment sample from the piston core for select sites. Eight types of media were used for anaerobic enrichments. These were designed to target denitrifiers, manganese reducers, iron reducers, sulfate reducers with acetate, sulfate reducers with malate, methyltrophs, nitrogen fixers, and fermenters. Further inoculations were carried out promptly when the samples return to MPI.

For every site, a most probable number analysis was done for aerobic heterotrophs on samples taken from the top of the multicore. This is another way for determining the viability of the cells in the sediment and to give an estimate of cultivable cell counts.

For studies of the biosynthetic potential of microbes from subseafloor sedimentary communities in the South Pacific Gyre, a $3 \mathrm{~cm}^{3}$ sample was collected from the piston core at intervals of $\sim 1 \mathrm{~m}$ and from the multicorer at $10 \mathrm{~cm}$ increments. When possible, the sediment from around the subsampled site of the multicorer was collected, extracted for nutrients, and sterilized for use as a natural growth media.

Cultivation efforts focused on the isolation of marine actinobacteria and Bacillus sp. since these have historically been rich resources for the discovery of biomedically promising metabolites. Aliquots of sediment were subjected to heat shock, alcohol treatment, or dry stamping to help select for the desired bacteria. Treated samples, in addition to an untreated aliquot, were plated onto various oligotrophic media and incubated at $4^{\circ} \mathrm{C}$. The Yayanos pourtube method was used to culture selected sediment samples under environmentally relevant pressures. This method involves suspending cells in agar just prior to solidifying, immobilizing the cells. Individual colonies grown under high pressure can then be easily isolated to determine if pressure helps select 
for novel strains. Due to space restraints, the samples incubated under 5800 psi at $4^{\circ} \mathrm{C}$ were composed mostly of the untreated aliquots from the uppermost sediments. On the ship, there was little visible growth. However, upon growth, reisolations of the cultured bacteria will be continued until pure cultures are obtained for further studies to be conducted at URI. In these postexpedition studies, DNA will be extracted from all isolated bacteria for phylogenetic analysis. Additionally, isolates will be cultivated in seawater broth media, and culture extracts will be evaluated for the production of antibiotics using bioassays. Chemical and spectroscopic analysis (natural magnetic remanence and high-pressure liquid chromatography-mass spectroscopy) will be used to probe for the production of novel metabolites.

\section{Protocols for microbiological studies of manganese nodules (Harrison, Horn)}

Manganese nodules were recovered from the cored sediment at most sites. Two separate suites of nodules were carefully sampled for postcruise study of their microbial communities. Sampling of the first set of manganese nodules will be used to characterize the microbial communities by DNA analysis, FISH, and electron microscopy. The separate sample sets were taken for various regions of the nodule (up to two distinct regions within the nodule and the surface). Nodule samples were saved for further geochemical, isotopic, and mineralogical analyses to determine specific microbe-mineral interactions on and within nodules, the extent to which these influence nodule formation and growth, and to use isotopic analyses to attempt a measure of nodule growth rates. The goal of nodule sampling is to characterize the microbial community on nodules with the hope of providing clues as to nodule formation and growth.

The first suite of nodules (from Sites SPG-2, SPG-9, and SPG-10) was processed by chipping off 0.1 to 1.5 $\mathrm{mm}$ diameter pieces of whole nodules with a sterilized hammer and chisel. The chips were then transferred to subsamples using sterilized tweezers. Each subsampling set consists of up to fourteen 1 to 1.5 $\mathrm{mL}$ samples processed as follows: up to 10 subsamples frozen at $-80^{\circ} \mathrm{C}$ for DNA extraction, up to 2 samples fixed in $4 \%$ paraformaldehyde, then centrifuged and rinsed twice with a 1:1 mixture of PBS/ethanol and stored at $4^{\circ} \mathrm{C}$ for FISH, and up to 2 samples fixed in $2.5 \%$ glutaraldehyde and stored at $4^{\circ} \mathrm{C}$ for electron microscopy (EM). Separate subsample sets are taken for various regions of the nodule (up to three distinct regions within the nodule and the exterior surface). For example, the nodule sampled for Core
SPG10-M1 was split into four sections: the outer and inner surfaces of the external layers, sediment trapped within the nodule, and the inner core. Remaining nodule samples are saved for further geochemical, isotopic, and mineralogical studies.

The second suite of samples consists of three small nodules fixed with $1 \%$ paraformaldehyde for shorebased microscopy and additional nodules frozen at $80^{\circ} \mathrm{C}$ for later DNA extraction along with associated sediment. This sample set will further be mineralogically and chemically characterized by XRD and SEMEDS.

\section{Protocols for microbiological studies of altered basalts (Horn)}

Altered basalts were recovered from the base of the cored sediment at two sites for a total of three samples (SPG3-P1, SPG3-P2, and SPG7-P1). These were carefully sampled for postcruise study of their microbial communities.

For comparison to microbial communities in the underlying basaltic glass, the deepest sediments recovered at these sites were sampled for characterization of the microbial communities by DNA analysis, FISH, and EM. All samples will be processed at USC. Sediment volume $(10 \mathrm{~mL})$ of sediment was sampled from the sediment/basalt interface using a cut-off autoclaved syringe. The sediment was suspended in a 1:1 ratio of bottom water that had been filtered at $0.2 \mu \mathrm{m}$ and autoclaved (FABW) to create a sediment slurry. Fourteen 1-1.5 mL subsamples were taken with 10 subsamples for DNA extraction. Two samples were fixed in $4 \%$ paraformaldehyde, centrifuged and rinsed twice with 1:1 PBS/ethanol, and stored at $4^{\circ} \mathrm{C}$ for FISH. Two samples were fixed in $2.5 \%$ glutaraldehyde and stored at $4^{\circ} \mathrm{C}$ for $\mathrm{EM}$. The remaining sample was then used for a series of four enrichment cultures in FABW stored at $4^{\circ} \mathrm{C}$, unamended, $10 \mathrm{mM}$ nitrate, $10 \mathrm{mM}$ ammonia, and $5 \mathrm{mM}$ nitrite and 5 $\mathrm{mM}$ ammonia enriched. The goal of the DNA analysis and microscopy is to compare the bottommost recovered sediment microbial communities to the basalt glass communities recovered. The goal of the enrichment cultures is to target microbes involved in the nitrogen cycle in the subsurface for further characterization and potential isolation.

Sampling of the basaltic glass followed the same sampling plan as the overlying sediments, with the addition of FeS gradient tubes, culturing, and geology samples taken. Chips of basalt 0.5 to $1.5 \mathrm{~mm}$ diameter were used instead of a slurry. The gradient tubes are as described by Emerson and Floyd (2005) with the substitution of FABW for modified Wolfe's mineral medium. Additional gradient tubes were 
amended with $100 \mu \mathrm{L}$ of $200 \mathrm{mM}$ nitrate or nitrite added to the top of the overlying plug and allowed to diffuse into the medium before inoculation with chips of glass 1-4 $\mathrm{mm}$ in diameter. The inoculated tubes were stored at $4^{\circ} \mathrm{C}$. The culturing samples consist of basalt glass immersed in FABW and stored at $4^{\circ} \mathrm{C}$ for later use. The geology samples are for geochemical, isotopic, and mineralogical characterization.

\section{Water column sampling and sample handling protocols (Halm, Dorrance)}

At each site, water from two to three depths was taken by a CTD Rosette. Surface water was also taken. The principal shipboard focus of water column analyses was on nitrogen fixation rates and assimilation rates for organic and inorganic nitrogen. For this work, water samples were incubated with ${ }^{15} \mathrm{~N}$-labeled nitrogen gas, ammonium, and leucine. With the isotopic ratios, rates can be calculated. $\mathrm{N}_{2}$ fixation was expected to be the main source of nutrient nitrogen. Subsamples were also taken for CARDFISH study and other molecular analyses, to identify diazotroph bacteria groups and to quantify the activity of the nifH gene (which is responsible for nitrogen fixation) (Halm et al., submitted). Nutrient concentrations define the chemical environment of the samples.

\section{Concentration/temperature/depth recorder sampling}

At all 11 sites, samples were taken from three or four depths with a CTD rosette. The depths sampled depended on the occurrence of chlorophyll in the water. These water samples $(15-25 \mathrm{~L})$ were taken from the chlorophyll maximum and two other depths. Seawater from the seawater supply line in the Roger Revelle Hydro Lab was taken as a surface water sample.

\section{Nitrogen fixation}

To $1 \mathrm{~L}$ of seawater, $4 \mathrm{~mL}{ }^{15} \mathrm{~N}_{2}$ gas and $50 \mu \mathrm{L}^{13} \mathrm{C}$-bicarbonate $(0.1 \mathrm{M}$ end concentration) were added and incubated for 3-6 h under in situ conditions. The samples were filtered on GF/F filters and frozen at $-20^{\circ} \mathrm{C}$ for transport to MPI. For each depth, $1 \mathrm{~L}$ was incubated in light and one in dark. As a control, $1 \mathrm{~L}$ of surface water was handled like the other samples, but labels were added immediately before filtering and freezing.

\section{Nitrogen assimilation}

For organic and inorganic N-uptake at nine stations, ${ }^{15} \mathrm{NH}_{4}$ (2 mM end concentration) or ${ }^{15} \mathrm{~N}$-leucine $(0.2$ $\mathrm{mM}$ end concentration) was added together with ${ }^{13} \mathrm{C}$-bicarbonate to $250 \mathrm{~mL}$ of surface water, and at four stations to $250 \mathrm{~mL}$ of water from $40 \mathrm{~m}$ depth, incubated for 3-6 $\mathrm{h}$ in light and dark, filtered, and frozen at $-20^{\circ} \mathrm{C}$. At every station, $4-8 \mathrm{~L}$ of water was filtered as background. The isotopic ratios were measured by mass spectrometry in Bremen postcruise.

\section{Sorting}

At some stations, $1 \mathrm{~L}$ of water from the chlorophyll maximum was incubated with ${ }^{15} \mathrm{~N}_{2}$ and ${ }^{13} \mathrm{C}$-bicarbonate, filtered on two GTTP filters, fixed with paraformaldehyde (PFA), and frozen at $-20^{\circ} \mathrm{C}$. In Bremen, the filtered cells were resuspended and sorted by flow cytometry. After sorting, the isotopic ratios of sorted bacteria groups were measured.

\section{Nutrients}

For nutrient measurement, $50 \mathrm{~mL}$ of every depth was frozen. Ammonium was measured on board.

\section{CARD-FISH}

Aliquots of 15-30 mL of every depth were fixed with PFA (1 $\mathrm{M}$ end concentration), filtered on GTTP filters, and stored at $-20^{\circ} \mathrm{C}$.

\section{DNA/RNA filters}

For molecular work, 2-10 L from every depth were filtered and frozen at $-80^{\circ} \mathrm{C}$.

\section{Diversity}

For postcruise tag sequencing studies of bacterial diversity, $5 \mathrm{~L}$ of seawater was taken from the depth of the chlorophyll maximum of each site, filtered, and stored at $-80^{\circ} \mathrm{C}$ for postcruise analysis at the Marine Biological Laboratory (Woods Hole, USA) as part of the International Census of Marine Microbes.

\section{Cell enumeration}

For postcruise cell counts, $18-20 \mathrm{~mL}$ of seawater was stored with formaldehyde in a Falcon tube and refrigerated.

\section{Operations Ship operations}

The KNOX-02RR expedition began in Apia, Samoa, on 18 December 2006 and ended in Dunedin, New 
Zealand, on 27 January 2007. During the cruise, we surveyed and cored 11 sites in the region of the South Pacific Gyre. Details of the survey, lander, and coring operations are provided in Table T6.

\section{Deck operations}

\section{Deployments of towed gear and other underway gear}

The Roger Revelle departed Apia, Samoa, on the Julian day 352 of 2006 at $0300 \mathrm{~h}$ Universal Time Coordinated, beginning the KNOX-02RR cruise. The cruise schedule involved several transits between sampling locations. At each location, a seismic survey was conducted prior to coring operations. Underway data collection began upon departure from the Samoa Exclusive Economic Zone (EEZ). Data were collected on a continuous basis from the acoustic Doppler current profiler (ADCP), hydrographic Doppler sonar system (HDSS), gravimeter, and the meteorological acquisition system (MAS). The MAS data include the ship's latitude, longitude, course over ground, speed over ground, speed over water, gyro compass reading, depth in meters, air temperature, barometric pressure, relative humidity, dew point, relative wind speed and direction, true wind speed and direction, and salinity (psu). Transits outside of any EEZ included data collection with the multibeam EM12, Knudsen 320 B/R echo sounder, and Marine Magnetics SeaSpy magnetometer. Time and location of data acquisition are detailed below. Losses of data for $1 \mathrm{~h}$ or less caused by equipment malfunctions are not documented.

Logging of continuous and transit data began upon departure from the EEZ on Julian day 354 at $0615 \mathrm{~h}$ $\left(16645.77^{\circ} \mathrm{W}, 2157.11^{\circ} \mathrm{S}\right)$. The magnetometer was retrieved for the beginning of the first seismic survey on Julian day 354 at $1700 \mathrm{~h}\left(16552.44^{\circ} \mathrm{W}\right.$, $\left.2354.341^{\circ} \mathrm{S}\right)$. The magnetometer was redeployed and logging of all transit data commenced on Julian day 356 at $0425 \mathrm{~h}\left(16535.04^{\circ} \mathrm{W}, 2351.71^{\circ} \mathrm{S}\right)$.

The magnetometer was retrieved for maintenance at 1633 on Julian day $356\left(16306.884^{\circ} \mathrm{W}, 2430.642^{\circ} \mathrm{S}\right)$ and redeployed at $0000 \mathrm{~h}$ on Julian day 357 $\left(16142.39^{\circ} \mathrm{W}, 2451.32^{\circ} \mathrm{S}\right)$.

The magnetometer was stopped for a seismic survey on Julian day 357 at $2244 \mathrm{~h}\left(15710.97^{\circ} \mathrm{W}\right.$, $\left.2557.34^{\circ} \mathrm{S}\right)$. The multibeam and echo sounder were secured on Julian day 358 at $0823 \mathrm{~h}\left(15653.67^{\circ} \mathrm{W}\right.$, $\left.2603.09^{\circ} \mathrm{S}\right)$. The magnetometer was redeployed for logging on Julian day 359 at $0524 \mathrm{~h}\left(15628.40^{\circ} \mathrm{W}\right.$, $\left.2607.97^{\circ} \mathrm{S}\right)$. The multibeam and echo sounder recommenced logging on the same day at $0619 \mathrm{~h}$ $\left(15616.49^{\circ} \mathrm{W}, 2610.97^{\circ} \mathrm{S}\right)$.
The magnetometer was stopped for a seismic survey on Julian day 360 at $2005 \mathrm{~h}\left(14831.34^{\circ} \mathrm{W}\right.$, $\left.2751.47^{\circ} \mathrm{S}\right)$. The multibeam and Knudsen echo sounder were secured on Julian day 361 at $0244 \mathrm{~h}$ $\left(14835.47^{\circ} \mathrm{W}, 2756.56^{\circ} \mathrm{S}\right)$ and returned to logging on Julian day 362 at $0010 \mathrm{~h}\left(14835.35^{\circ} \mathrm{W}, 2756.87^{\circ} \mathrm{S}\right)$.

All underway logging was stopped for the Cook Islands EEZ on Julian day 362 at $0237 \mathrm{~h}\left(14807.23^{\circ} \mathrm{W}\right.$, $2752.84^{\circ} \mathrm{S}$ ). The magnetometer was redeployed and all underway logging recommenced on Julian day 363 at $1139 \mathrm{~h}\left(14044.43^{\circ} \mathrm{W}, 2652.52^{\circ} \mathrm{S}\right)$.

The magnetometer was stopped for seismic survey on Julian day 365 at $0206 \mathrm{~h}\left(13754.21^{\circ} \mathrm{W}\right.$, $\left.2627.21^{\circ} \mathrm{S}\right)$. The multibeam was secured on Julian day 364 at $0725 \mathrm{~h}\left(13756.42^{\circ} \mathrm{W}, 2628.96^{\circ} \mathrm{S}\right)$. The magnetometer, echo sounder, and multibeam recommenced logging on Julian day 365 at $0250 \mathrm{~h}$ $\left(13750.87^{\circ} \mathrm{W}, 2630.97^{\circ} \mathrm{S}\right)$.

The magnetometer was retrieved for seismic survey and stopped logging on Julian day 001 at $1015 \mathrm{~h}$ $\left(13128.00^{\circ} \mathrm{W}, 2826.88^{\circ} \mathrm{S}\right)$. The multibeam and echo sounder were secured on the same day at $1615 \mathrm{~h}$ $\left(13123.661^{\circ} \mathrm{W}, 2825.242^{\circ} \mathrm{S}\right)$. The multibeam and echo sounder recommenced logging on Julian day 002 at $1144 \mathrm{~h}\left(13122.716^{\circ} \mathrm{W}, 2826.13^{\circ} \mathrm{S}\right)$, and the magnetometer was redeployed and logging on the same day at $1215 \mathrm{~h}\left(13118.11^{\circ} \mathrm{W}, 2826.34^{\circ} \mathrm{S}\right)$.

The magnetometer was retrieved for seismic survey and stopped logging on Julian day 004 at $0339 \mathrm{~h}$ $\left(12256.89^{\circ} \mathrm{W}, 2753.751^{\circ} \mathrm{S}\right)$. The multibeam and echo sounder were secured on the same day at $1127 \mathrm{~h}$ $\left(12312.86^{\circ} \mathrm{W}, 2754.87^{\circ} \mathrm{S}\right)$. The multibeam and echo sounder resumed logging on Julian day 005 at 0732 $\mathrm{h}\left(12308.31^{\circ} \mathrm{W}, 2754.99^{\circ} \mathrm{S}\right)$. The magnetometer was redeployed and logging on same day at $0754 \mathrm{~h}$ $\left(12303.42^{\circ} \mathrm{W}, 2754.97^{\circ} \mathrm{S}\right)$ but data are not available from 1845 to $2113 \mathrm{~h}$ due to error.

The magnetometer was retrieved for seismic survey and stopped logging on Julian day 006 at 0715 $\left(11750.28^{\circ} \mathrm{W}, 2754.01^{\circ} \mathrm{S}\right)$. The multibeam and echo sounder were secured on the same day at 1516 $\left(11737.28^{\circ} \mathrm{W}, 2744.51^{\circ} \mathrm{S}\right)$. The multibeam and echo sounder logging recommenced on Julian day 007 at $1118\left(11737.78^{\circ} \mathrm{W}, 2744.88^{\circ} \mathrm{S}\right)$. The magnetometer was redeployed and logging same day at 1136 $\left(11730.94^{\circ} \mathrm{W}, 2747.08^{\circ} \mathrm{S}\right)$.

The magnetometer was retrieved for seismic survey and stopped logging on Julian day 010 at 2258 $\left(13305.41^{\circ} \mathrm{W}, 3803.63^{\circ} \mathrm{S}\right)$. The multibeam and echo sounder were secured on Julian day 011 at 0642 $\left(13305.49^{\circ} \mathrm{W}, 3803.68^{\circ} \mathrm{S}\right)$. The magnetometer was redeployed and logging on Julian day 012 at 0555 $\left(13307.44^{\circ} \mathrm{W}, 3802.90^{\circ} \mathrm{S}\right)$. The multibeam and echo 
sounder logging recommenced on the same day at 0605 at same location.

The magnetometer was retrieved for seismic survey and stopped logging on Julian day 013 at 0811 $\left(13920.98^{\circ} \mathrm{W}, 3910.63^{\circ} \mathrm{S}\right)$. The multibeam and echo sounder were secured on the same day at 1855 $\left(13948.03^{\circ} \mathrm{W}, 3918.617^{\circ} \mathrm{S}\right)$. The multibeam and echo sounder logging recommenced on Julian day 014 at $2143\left(13944.43^{\circ} \mathrm{W}, 3918.12^{\circ} \mathrm{S}\right)$ and the magnetometer was redeployed same day at $2208\left(13952.41^{\circ} \mathrm{W}\right.$, $3919.08^{\circ} \mathrm{S}$ ).

The magnetometer was not responding, and logging was secured on Julian day 14 at $2315\left(14010.45^{\circ} \mathrm{W}\right.$, $\left.3923.28^{\circ} \mathrm{S}\right)$. The problem was solved, and logging recommenced on Julian day $151116\left(14308.811^{\circ} \mathrm{W}\right.$, $4000.161^{\circ} \mathrm{S}$ ).

The magnetometer was retrieved for seismic survey and stopped logging on Julian day 017 at 0053 $\left(15280.48^{\circ} \mathrm{W}, 4156.09^{\circ} \mathrm{S}\right)$. The echo sounder and multibeam were secured on the same day 0804 $\left(15302.98^{\circ} \mathrm{W}, 4148.95^{\circ} \mathrm{S}\right)$. The multibeam and echo sounder logging recommenced on Julian day 018 at $0617\left(15306.71^{\circ} \mathrm{W}, 4150.70^{\circ} \mathrm{S}\right)$, and magnetometer was redeployed and logging at $0654\left(15316.106^{\circ} \mathrm{W}\right.$, $\left.4155.33^{\circ} \mathrm{S}\right)$.

The magnetometer was retrieved for seismic survey and stopped logging on Julian day 020 at 0445 $\left(16257.62^{\circ} \mathrm{W}, 4559.84^{\circ} \mathrm{S}\right)$, and the echo sounder and multibeam were secured at $1326\left(16311.05^{\circ} \mathrm{W}\right.$, $\left.4557.85^{\circ} \mathrm{S}\right)$. Magnetometer logging recommended at 1208 on Julian day $21\left(16315.11^{\circ} \mathrm{W}, 4557.82^{\circ} \mathrm{S}\right)$, while echo sounder and multibeam recommenced on the same day at $1214\left(16316.23^{\circ} \mathrm{W}, 4557.81^{\circ} \mathrm{S}\right)$.

Permission was granted to record data inside the New Zealand EEZ. New data files were started on Julian day 022 at $2300\left(17102.23^{\circ} \mathrm{W}, 4553.58^{\circ} \mathrm{S}\right)$. The magnetometer was retrieved and stowed on Julian day 25 at $0445\left(17713.86^{\circ} \mathrm{E}, 4547.15^{\circ} \mathrm{S}\right)$. We stopped multibeam logging on the same day at 1900 $\left(17431.17^{\circ} \mathrm{E},{ }^{4} 546.11^{\circ} \mathrm{S}\right)$ and stopped the echo sounder at $2000\left(17421.58^{\circ} \mathrm{E}, 4545.58^{\circ} \mathrm{S}\right)$, marking the end of data logging for KNOX-02RR.

\section{Coring operations}

Additional information on coring operations is presented in Table T6.

At Site SPG-1, we deployed, in order, a $10 \mathrm{ft}$ benthos gravity corer (2.5 inch), a $30 \mathrm{ft}$ piston corer with no pigs, and a $10 \mathrm{ft}$ trigger corer with seven lead rings, a multicorer, the Scripps CTD, and a $30 \mathrm{ft}$ piston corer with no pigs and a $10 \mathrm{ft}$ trigger corer. The second piston corer had four thermistors.
At Site SPG-2, we deployed a multicorer before moving away from the coring station to deploy the MPI lander. The lander's ballast weights were lost during deployment. Consequently, the lander did not sink. Its mast was broken while floating, and immediate recovery was initiated. We returned to the coring station to deploy, in order, a $30 \mathrm{ft}$ piston corer with no pigs and a $10 \mathrm{ft}$ trigger corer, the Scripps CTD, and a second $30 \mathrm{ft}$ piston corer with no pigs and a $10 \mathrm{ft}$ trigger corer. The second piston core had three thermistors.

At Site SPG-3, deployed a benthos gravity core (2.5 inch) and the multicorer before moving away from the coring station to deploy the MPI lander. We then returned to the coring station to deploy a $20 \mathrm{ft}$ piston core with four thermistors and a $10 \mathrm{ft}$ trigger core. The cutting shoe of the piston corer was deformed by impact with basalt at the base of the sediment column. We then deployed, in order, the CTD and a second $20 \mathrm{ft}$ piston corer with four thermistors and a $10 \mathrm{ft}$ trigger corer. The cutting shoe of this piston corer was also deformed. The cutting shoe and core catcher were lost from the trigger core, and the cutting shoe rivets were sheared off. We then recovered the lander and began the transit to Site SPG-4 (IODP Site U1367).

At Site SPG-4, we deployed, in order, the multicorer, a benthos gravity corer ( 2.5 inch), a $30 \mathrm{ft}$ piston corer with a $10 \mathrm{ft}$ trigger corer, the CTD, and a second $30 \mathrm{ft}$ piston corer with a $10 \mathrm{ft}$ trigger corer with seven lead rings.

At Site SPG-5, we deployed a benthos gravity corer ( 2.5 inch) and then moved away from the coring site to deploy the MPI lander. We returned to the coring station to deploy a $30 \mathrm{ft}$ piston corer with a $10 \mathrm{ft}$ trigger corer with eight lead rings. We recovered the lander, after which we returned to the coring station to deploy, in order, a multicorer, the CTD, and a $30 \mathrm{ft}$ piston corer with four thermistors and a $10 \mathrm{ft}$ trigger corer with eight lead rings.

At Site SPG-6, we deployed a benthos gravity corer (2.5 inch.), found the recovered core unsatisfactorily short, and moved the station. We deployed a second benthos gravity corer (2.5 inch), which recovered nearly the same amount of sediment as the first core, the CTD, a $20 \mathrm{ft}$ piston corer with no pigs and a $10 \mathrm{ft}$ trigger corer with eight lead rings, a multicorer, and a $20 \mathrm{ft}$ piston corer with four thermistors and a $10 \mathrm{ft}$ trigger corer. Because of the stiffness of the sediment, this second piston corer had two pigs in the core bomb.

At Site SPG-7, we deployed a benthos gravity core (2.5 inch) and moved away from the coring station 
to deploy the MPI lander. We returned to the coring station and deployed, in order, a multicorer and a 20 $\mathrm{ft}$ piston corer with no pigs, four thermistors, and a $10 \mathrm{ft}$ trigger corer. The piston corer struck basement and bent the core sheath. After retrieval, the piston corer was disassembled to retrieve the core liner and core. We deployed the CTD and a trigger gravity corer (4 inch), after which we recovered the lander. After lander recovery, we returned to the coring station to deploy a jumbo gravity corer (4 inch) with no pigs.

There were no coring operations at Site SPG-8. It was not on the final cruise track because there was not enough time to survey all 12 sites.

At Site SPG-9, we deployed a benthos gravity corer (2.5 inch), a multicorer, a $20 \mathrm{ft}$ piston corer with no pigs and a $10 \mathrm{ft}$ trigger corer, the CTD, and a $20 \mathrm{ft}$ piston corer with four thermistors, no pigs, and a 10 $\mathrm{ft}$ trigger corer.

At Site SPG-10, we deployed a multicorer and then moved away from the coring station to deploy the MPI lander. We returned to the coring station to deploy a $20 \mathrm{ft}$ piston corer with no pigs and a $10 \mathrm{ft}$ trigger corer with nine lead rings. This piston corer was lost at the seafloor; there was no pullout tension and the wireline parted immediately below the trigger arm book clamp. The cutting shoe of the trigger corer was severely cut and torn; the indentations in the cutting edge of the shoe are sharp-edged and square, as if the shoe was slammed against the squared edge of a metal plate several times. Despite the damage to this cutting shoe and the loss of the piston corer, an intact core was recovered from the trigger corer. After this loss, we deployed, in order, the CTD and a $20 \mathrm{ft}$ piston corer with no pigs and a $10 \mathrm{ft}$ trigger corer with nine lead rings. We recovered the lander, after which we deployed a $20 \mathrm{ft}$ piston corer with no pigs, three thermistors, and a $10 \mathrm{ft}$ trigger corer with nine lead rings.

At Site SPG-11, we deployed, in order, a benthos gravity corer (2.5 inch) and a $20 \mathrm{ft}$ piston corer with no pigs and a $10 \mathrm{ft}$ trigger corer with 10 lead rings. As at Site SPG-10, the piston corer was lost at the seafloor; again there was no pullout tension and the wireline parted at the base of the trigger arm book clamp. We deployed, in order, the CTD, a multicorer, a $15 \mathrm{ft}$ trigger gravity corer (4 inch) with 10 lead rings, and a second $15 \mathrm{ft}$ trigger gravity corer (4 inch) with 10 lead rings.

At Site SPG-12, we deployed, in order, a $15 \mathrm{ft}$ trigger gravity corer (4 inch) with 10 lead rings and a multicorer. Sea state was relatively high. During multicorer deployment, a tag line caught on a corer leg and was cut at ship's rail. One tube closed before the multicorer left the surface. The multicorer returned with almost no sediment. We deployed a $15 \mathrm{ft}$ trigger gravity corer (4 inch) with 10 lead rings, CTD, a $20 \mathrm{ft}$ trigger gravity corer (4 inch) with 10 lead rings, and a $20 \mathrm{ft}$ trigger gravity corer (4 inch) with 10 lead rings before leaving the station for our transit to Dunedin, New Zealand.

\section{Lander operations}

Lander deployments and operations are described in Table T7.

\section{Concentration/temperature/depth recorder operations}

At all 11 sites surveyed, a CTD Rosette with twentyfour $2.5 \mathrm{~L}$ Niskin bottles took water from three to five depths. Recorded data at all sites included temperature, pressure, salinity, conductivity, and fluorescence. Location, date, time, and depth data are presented in Table T8.

A list of subsamples taken from the CTD casts is presented in Table T9.

\section{Argo float deployment}

Twelve Argo floats were deployed during Cruise KNOX-02RR. These floats were deployed in support of the worldwide network of Argo floats (www.argo.net). This organization has the goal of deploying 3000 floats by the end of 2007 with a spacing of approximately $3^{\circ}$ in the world ocean. These floats autonomously collect pressure, temperature, and salinity data in vertical profiles $(\sim 200$ data points per profile) taken on a 10 day cycle (Fig. F6). Each float is designed to operate for $\sim 4-5 \mathrm{y}$. These data will be used to quantify changes in the oceanic heat and freshwater budgets and transport. The data will be used to initialize coupled ocean-atmosphere models.

The floats were deployed by lowering by hand with a tag line from the starboard quarter while the ship was under way at 6-12 kt. The release mechanism was activated upon contact with the water and the tag line, nylon straps, and release mechanism were recovered.

Table T10 contains information regarding the time and location that the Argo floats were deployed. The first three floats are ballasted to $1450 \mathrm{db}$ and the remaining nine to $1600 \mathrm{db}$. The data from these floats can be found at sio-argo.ucsd.edu/table.html.

\section{Core recoveries and distributions}

Cores and core flow for recovered piston, trigger, and gravity cores are shown in Table T11. Details of the 
subsampling and curation of the cores are given in a separate file. Figures F7 and F8 provide a graphic illustration of core recovery for each site (this figure provides multicore recovery for only the first multicore at each site). Recovery and distribution of samples from the multicorers are given in a separate file.

\section{Results}

\section{Geologic context/geophysical survey (Abrams, Harris, Pockalny)}

\section{Underway geophysical survey (Abrams, Pockalny)}

Underway geophysical data were collected across nearly the entire width of the Pacific plate in the Southern Hemisphere between $20^{\circ}$ and $45^{\circ} \mathrm{S}$ (Fig. F9). The mapped ocean crust was accreted along at least four different plate boundaries (e.g., PacificPhoenix, Pacific-Antarctic, Pacific-Farallon, and Pacific-Nazca). Crustal ages range from $\sim 100 \mathrm{Ma}$ (Chron 34n) at the beginning of the survey to about $6 \mathrm{Ma}$ (Chron 3An.1n) at the easternmost limit of the survey. Calculated spreading rates range from slowintermediate $\left(<20 \mathrm{~km} / \mathrm{m} . y_{\text {., }}\right.$ half-rate $)$ to ultrafast (>80 km/m.y., half-rate).

The location of seismic surveys and coring stations also covered a relatively wide range of crustal ages, spreading rates, and tectonic/volcanic environments (Table T12). The depth and crustal age of each coring site correlates well with the predicted depth versus age curve (Stein and Stein, 1992), which suggests the sites are located on representative crust (Fig. F10). Calculated spreading rates at each site are somewhat biased toward fast and ultrafast spreading rates (28-95 km/m.y., half-rate). Surprisingly, the 95 $\mathrm{km} / \mathrm{m} . \mathrm{y}$. value is one of the fastest spreading halfrates measured globally. The abyssal hill fabric is relatively well defined for most coring sites. However, off-axis volcanism at Site SPG-5 and, possibly, Site SPG-6 masked the original seafloor fabric. Sediment thickness ranges from $<3 \mathrm{~m}$ to $130 \mathrm{~m}$ and generally increases to the west and south of our survey area. This sediment thickness trend is consistent with greater sediment cover on older crust and on crust located farther away from the center of the gyre. The notable exception to this trend is along the northern transect on crust accreted along the Pacific-Farallon spreading system and older than $\sim 30 \mathrm{Ma}$. Sediment at each of the sites generally appears as pelagic drape, with some localized mass wasting deposits. Seismic images also reveal areas of bottom current activity occasionally resulting in localized scouring of all sediment above volcanic basement (e.g., Site SPG-5).

\section{Thermal gradient measurements (Harris)}

The time series from a successful deployment of thermistors shows the temperature-time history of coring operations and the penetration of the piston core in the sediments (Fig. F11). The frictional heating of penetration, asymptotic decay of temperatures, and frictional heating of pullout is clear. The bottom water temperature is $\sim 1.5^{\circ} \mathrm{C}$.

\section{Thermal conductivity measurements (Harris)}

Thermal conductivity results for Sites SPG-2 through the upper portion of Site SPG-5 are very consistent with values $\sim 0.72 \mathrm{~W}(\mathrm{~m} \cdot \mathrm{K})$ (Fig. F12). The lower portion of the penetrated sediment at Site SPG-5 shows somewhat higher thermal conductivity as the sediment goes from a red clay to carbonaceous ooze. The increase in thermal conductivity with depth at Site SPG-6 correlates to an increase in density and is consistent with compaction.

\section{Heat flow determinations (Harris)}

Heat flow values are plotted as a function of age (Fig. F13). Heat flow determinations that fall off the bestfitting model are interpreted as indicating advective fluid flow. With the exception of Sites SPG-2 and SPG-4, heat flow values are thought to reflect advective fluid flow. Existing heat flow data (Fig. F2) around Sites SPG-1 and SPG-4 show large variability, which is also indicative of advective fluid flow (Fig. F14).

\section{Oceanographic context (Dorrance, Goldstein, Halm, Morse)}

\section{Concentration/temperature/depth recorder results (Dorrance, Halm)}

The data taken by the CTD show a slight decrease in salinity from 35.57 to $35.6 \mathrm{psu}$ at Site SPG-1 in the west to 35.26 psu at Site SPG-6 in the east at a depth of 80 meters below sea level (mbsl) and an increase in the surface water to $36.1 \mathrm{psu}$ at Site SPG-7 (Table T13). The temperature at the water surface increased from $23^{\circ}$ to $24^{\circ} \mathrm{C}$. During the northern west-east transect, the chlorophyll maximum sank from 100 mbsl at Site SPG-1 to 200 mbsl at Site SPG-7. The chlorophyll concentration decreased from $0.39 \mu \mathrm{g} / \mathrm{L}$ at Site SPG-1 to $0.8 \mu \mathrm{g} / \mathrm{L}$ at Site SPG-7. The ammonium concentration increased from $0.11 \mu \mathrm{M}$ at Site SPG-1 to $0.054 \mu \mathrm{M}$ at Site SPG-7. 
The sites of the southern transect are characterized by different near-surface water mass properties than the sites of the northern transect. At the southern sites, salinity is between 34.24 and 35.6 psu and the water is colder $\left(10.5^{\circ}-11.5^{\circ} \mathrm{C}\right.$ at $100 \mathrm{mbsl}$ to $17.5^{\circ} \mathrm{C}$ at $20 \mathrm{mbsl})$. Chlorophyll occurs at all depths in a range of $0.2-0.3 \mu \mathrm{g}$ chl-a/L, with its maximum at 100 mbsl and greater depths. At Sites SPG-10 and SPG-11, a smaller second chlorophyll maximum occurs beneath the thermocline. From Site SPG-9 onward, the ammonium concentration is between 0.096 and 0.29 $\mu \mathrm{M}$.

\section{Marine mammal monitoring and mitigation (Goldstein, Morse)}

For this expedition, the National Oceanographic and Atmospheric Administration/National Marine Fisheries Service (NOAA/NMFS) issued a Incidental Harassment Authorization (IHA) permit to Scripps Institution of Oceanography to authorize nonlethal takes of certain marine mammals incidental to a marine seismic survey in the South Pacific Ocean. Behavioral disturbance of marine mammals is considered to be "take by harassment" under the provisions of the US Marine Mammal Protection Act.

The temporary or permanent impact of seismic exploration and other anthropogenic sound sources to any marine mammals is unknown. Nonetheless, to minimize the possibility of an injurious effects (auditory or otherwise) and to document the extent and nature of any disturbance effects, NOAA/NMFS requires that seismic research conducted under an IHA include provisions to monitor for marine mammals, sea turtles, and other protected marine species and to shut down/power down the seismic sources when these animals are detected within designated safety radii. Safety radii were defined based on the estimated radius at which the received level of seismic sounds (on an rms basis) was expected to diminish to $180 \mathrm{~dB}$ at $1 \mu \mathrm{Pa}$, as specified by NMFS. The IHA also required monitoring and mitigation procedures to minimize potential harassment of sea turtles using the same safety zone.

Two marine mammal observers were onboard the cruise to monitor and mitigate as directed by the regulations described in the IHA permit. Observers stood watch for a total of $43.17 \mathrm{~h}$ during seismic operations and $306.95 \mathrm{~h}$ while seismic operations were secured. There were 23 sightings during the cruise (Table T14). No sightings were made during seismic operations.

\section{Sedimentology \\ (Hasiuk, Stancin)}

During the expedition, 11 sites were successfully cored on two transects of the South Pacific Ocean (D'Hondt et al., 2009). The sediment recovered constituted between $4 \%$ and $100 \%$ of the sediment present at each site (Fig. F15). The northern transect surveyed sites on progressively younger crust from west to east, and the southern transect surveyed sites on crust that generally increased in age from east to west. The easternmost site (SPG-7) is located at the center of the lowest productivity section of the ocean (as determined by satellite measurement of surface chlorophyll concentration).

The northern transect consisted of seven sites (SPG-1 -SPG-7) from $23.85^{\circ} \mathrm{S}, 165.64^{\circ} \mathrm{W}$ (5554 mbsl on $102.5 \mathrm{Ma}$ crust) to $27.68^{\circ} \mathrm{S}, 117.57^{\circ} \mathrm{W}(3920 \mathrm{mbsl}$ on 6.1 Ma crust). Sediment at the first four sites (SPG-1SPG-4) was homogeneous very dark brown clay (Fig. F16). Manganese nodules were common at the first three sites and rare at the fourth. There was some mottling, and smear slides showed micronodules and were barren of fossils. The first major change in sediment character occurred at Site SPG-5, with dark yellowish brown nannofossil-bearing clay at 100 cmbsf in Section 5. Washing of sediment at Sites SPG-3 and SPG-5 yielded cosmic spherules; sediments were not washed at other sites. Sites SPG-6 and SPG-7 had increasing amounts of calcareous nannofossils as the depth shoaled across the carbonate compensation depth.

The second transect consisted of four sites (SPG-9SPG-12) from $38.06^{\circ} \mathrm{S}, 133.09^{\circ} \mathrm{W}(5013 \mathrm{mbsl}$ on 39 Ma crust) to $45.96^{\circ} \mathrm{S}, 163.18^{\circ} \mathrm{W}(5310 \mathrm{mbsl}$ on $73 \mathrm{Ma}$ crust). The sediment from Site SPG9-11 is lithologically similar (homogeneous clay) to Sites SPG-1-SPG4 , yet was lighter in color (brown versus dark brown). Sediments at these sites also display extensive mottling (yellowish brown tubular mottles). Site SPG-12 was the only site cored outside of the South Pacific Gyre. It is dominated by siliceous ooze (abundant diatom debris and sponge spicules) and displays major gradational color changes on short spatial scales and several dark horizons, $2-10 \mathrm{~cm}$ thick. Recent worm burrows were also evident at Site SPG-12.

\section{Manganese nodules}

Approximately 260 manganese nodules were recovered from seven sites (SPG-1-SPG-4 and SPG-9-SPG11), ranging in size from a few millimeters to almost $10 \mathrm{~cm}$ in diameter. Cores at two sites had distinct $\mathrm{Mn}$ 
crusts: Site SPG-1 at 735-740 cmbsf and Site SPG-10 at 220-225 cmbsf. Almost all cores recovered from Site SPG-10 contained two nodules, with one at the surface and one at 30-50 cmbsf, both with an average diameter of $8 \mathrm{~cm}$. Most nodules recovered are spherical to subspherical, except for those at Site SPG-9, which are aggregates of centimeter-diameter nodules. Nodules recovered from Site SPG-4 and some from Site SPG-9 have encrusted anastamosing worm tubes, $0.1 \mathrm{~mm}$ in diameter and centimeters long, on nodules that average $1 \mathrm{~cm}$ in diameter. Smear slides included silt-sized nodules (micronodules) in almost all cases. Washing clay yielded silt- to sand-sized nodules (mininodules).

\section{Sedimentation rates}

By combining estimates of crustal age (interpreted from seafloor magnetic anomalies) with sediment thickness (interpreted from $3.5 \mathrm{kHz}$ seismic data), average sedimentation rates were calculated (Fig. F17; Table T15). In this calculation, no account was made for interstitial water volume or changes in interstitial water volume downcore.

For Sites SPG-1-SPG-3, sedimentation rate decreased from 0.7 to $0.08 \mathrm{~m} / \mathrm{m} . \mathrm{y}$., consistent with decreasing sediment supply at the more centrally located sites in the South Pacific Gyre. Sedimentation rates for Sites SPG-4-SPG-6 range from 0.3 to $1.1 \mathrm{~m} / \mathrm{m} . \mathrm{y}$., which may have resulted in part from increasing percentages of carbonate sediment caused by shallower depths. Site SPG-7 has a sedimentation rate of 0.2 $\mathrm{m} / \mathrm{m}$.y., which could reflect its location at the center of the South Pacific Gyre chlorophyll minimum or a diagenetic removal of carbonate. This rate is likely suggestive of background noncarbonate sedimentation rates at this location. Sites SPG-9-SPG-12 show a general increase in sedimentation rate from 0.5 to $1.8 \mathrm{~m} / \mathrm{m}$.y. as sites became increasingly more distal from the center of the gyre. Site SPG-12 had the highest sedimentation rate of all sites visited on the cruise because of its location on the outer portion of the South Pacific Gyre in more nutrient-rich waters.

Although the range in sedimentation rates calculated for these sites spans three orders of magnitude, these rates are still among the lowest sedimentation rates that occur on the Earth's surface.

\section{Physical properties (Hasiuk, Rogers, Stancin) \\ Core-logging results (Rogers)}

GEOTEK's software processed the raw data according to calibrations performed during the cruise. These parameters are stored in proprietary binary.pro files. The accompanying graphs of the processed data show section lengths, density, magnetic susceptibility, and $P$-wave velocity (Figs. F18, F19, F20, F21, F22, F23, F24, F25, F26, F27, F28). The attached graphs show the P1 core in red and the P2 core in green for the sites where both were taken. Other shorter cores are various colors. There is no processed gravity core data because of their smaller diameter.

The first necessary result is the $25 \mathrm{~cm}$ deionized water sample run before each core. This should be within $1 \%$ of $1 \mathrm{~g} / \mathrm{cm}^{3}$ with near-zero magnetic susceptibility for the subsequent data to be trusted. The gamma processing was recalibrated if this drifted. There are some obvious errors near the edge of each core caused by end cap thickness. These could be compensated for with further postprocessing, as the deionized water standard has the same end caps as the cores. The magnetic susceptibility loop seemed to have low spatial resolution, so edge effects of a few centimeters were unavoidable. These are especially bad in the P1 cores or other heavily sampled cores. The $P$-wave velocity rollers had some data quality issues. Electrical tape, end caps, dust, and other irregularities in the core liners caused poor connection and resulted in low $P$-wave amplitude. The velocity data are therefore noisier than they otherwise might be but still appear to be valid.

Most cores had homogeneous properties. Sites SPG1, SPG-2, SPG-5, and SPG-10 had some interesting features, although some of the early sites' magnetic data may have suffered from sudden temperature changes in the MST van. Logs of Site SPG-5 cores record the clay to carbonate transition at $6 \mathrm{mbsf}$, and logs of Site SPG-10 show manganese nodules at a variety of depths.

Further processing could include normalization of each core based on the measured and known densities of the calibration section. Edge effects could also be reduced using the same calibration section and the thickness deviations found in the raw data. The effects of temperature variations on magnetic susceptibility in the first two cores could also be better understood. If the magnetic signatures shown in those graphs are real, they show an interesting pattern.

\section{Conductivity results (Hasiuk, Stancin)}

Variability in conductivity among cores generally decreases from $30-45 \mathrm{mS} / \mathrm{cm}$ at the surface to $30-40$ $\mathrm{mS} / \mathrm{cm}$ at $\sim 2 \mathrm{mbsf}$, reflecting decreasing water content (Fig. F29). Below 2 mbsf, between-site variability increases, suggesting influence of diagenetic processes peculiar to each site. Cores SPG-1-P2, SPG-9P2, and SPG-10-P3 all show change in conductivity 
downcore, whereas the other cores recovered show little to no variability downcore.

\section{Biogeochemistry (Fischer, Fuldauer, Graham, Griffith, Schrum, Smith, Spivack) $\mathrm{O}_{2}$ distributions (Fischer)}

The differences between Sites SPG-1-SPG-11 in respect to oxygen profiles were low (D'Hondt et al., 2009; Fischer et al., 2009). The most obvious feature of the profiles measured on the cores is the presence of oxygen throughout the whole length of the cores (as deep as $8 \mathrm{~m}$ ) at all sites except Site SPG-12 (Fig. F30). At the time, this was the deepest oxygen penetration ever measured in marine sediments. All profiles show the highest drop in concentration within the uppermost 50 to $100 \mathrm{~cm}$. At greater depths, oxygen remained relatively constant or declined slightly and nearly linearly (on the order of a few micrometers per meter) with depth. These profiles indicate extremely low downward fluxes of oxygen and aerobic respiration rates.

Site SPG-12 differed completely from this pattern. Here, the oxygen penetration was limited to $\sim 100$ $\mathrm{cm}$.

Small-scale profiles measured with microelectrodes on multicores showed a zone of relatively high respiration, limited only to the uppermost few centimeters (Fig. F31), not to the first $\sim 50 \mathrm{~cm}$ (unlike in Fig. F30). This result is in good agreement with the in situ profiles obtained with the electrode profiler at Sites SPG-7 and SPG-10 (Fig. F32). The discrepancy between the small-scale electrode measurements and the measurements on the cores is most easily explained by a coring artifact, with the top section of the long cores (particularly the piston cores) mixed by initiation of the coring process.

\section{Interstitial water chemistry (Fuldauer, Graham, Griffith, Schrum, Spivack)}

At most of the sites, alkalinity concentrations are either relatively stable or shift to slightly higher values downcore (Fig. F33A) (D'Hondt et al., 2009). However, at Sites SPG-5 and SPG-7, alkalinity decreases in the deepest sediments, indicating alkalinity consumption or transport of alkalinity from the sediment to the underlying basement. The greatest change in alkalinity occurs at Site SPG-12, where it gradually increases from $2.6 \mathrm{mM}$ at the top of the core to $\sim 3.2 \mathrm{mM}$ at $2 \mathrm{mbsf}$ and then remains stable for the remainder of the core (to $5 \mathrm{mbsf}$ ). This result suggests that the shallowest sediments of Site SPG-12 are characterized by greater oxidation of organic matter than any of the other sediments recovered on this expedition.
Dissolved nitrate concentrations tend to be between $\sim 35$ and $\sim 45 \mu \mathrm{M}$ at Sites SPG-1 to SPG-11 (Fig. F33B) (D'Hondt et al., 2009). At these sites, nitrate is generally stable or increases slightly with sediment depth. These increases presumably result from oxidation of buried organic nitrogen. Gradual downcore decreases occur at Sites SPG-5 and SPG-7, perhaps due to transport of dissolved nitrate through the sediment to the underlying basement. Of these sites, Site SPG-11 has the most significant change in nitrate concentrations over the shortest distance; values increase by $\sim 11 \mu \mathrm{M}$ over $3.05 \mathrm{~m}$, indicating that organic nitrogen is oxidized at a much higher rate in the shallow sediment of this site than in the sediments of Sites SPG-1 through SPG-10. At Site SPG-12, dissolved nitrate decreases rapidly from a peak of 44 $\mu \mathrm{M}$ to zero at $\sim 2.5 \mathrm{mbsf}$, indicating significant nitrate reduction at that depth. This occurrence of nitrate reduction is consistent with the much higher levels of organic matter oxidation at that site than at the other South Pacific Gyre sites.

Measurements of dissolved sulfate concentrations at the South Pacific Gyre sites exhibit a fair bit of scatter (Fig. F33C). Scatter aside, dissolved sulfate concentrations appear to be basically stable or, perhaps, decrease slightly downcore at the various sites.

Chloride profiles tend not to show obvious trends downcore but exhibit scatter (Fig. F33D). At some sites, such as Sites SPG-1, SPG-6, and SPG-9, chloride concentrations appear to shift to higher values with depth in the sediment column. Error analysis for chloride, bromide, sulfate, and nitrate is based on average deviations of duplicate analyses of the same dilution.

The downcore bromide profiles show considerable scatter for nearly all sites. In general, bromide varies from $\sim 84$ to $88 \mu \mathrm{M}$. Site SPG-6 shows a distinct increase in bromide from the top of the core to $\sim 1$ mbsf, after which point the concentration decreases and stabilizes.

Methane concentrations are below our detection limit (1 ppm) at all sites.

\section{$\mathbf{H}_{2}$ distributions (Smith)}

Of the 167 sediment samples analyzed for $\mathrm{H}_{2}$ concentration, only four samples contained measurable amounts. No $\mathrm{H}_{2}$ was detected in any sample from Sites SPG-1-SPG-9. One sample at Site SPG-10 (0.7 mbsf) contained $35 \mathrm{nM} \mathrm{H}_{2}$. Samples collected immediately above $(0.5 \mathrm{mbsf})$ and below $(0.95 \mathrm{mbsf})$ this sample contained no detectable $\mathrm{H}_{2}$. The deepest sample analysed at Site SPG-12 contained $1315 \mathrm{nM}$ $\mathrm{H}_{2}$. 


\section{Microbial activity (Ferdelman, Soffientino)}

\section{Hydrogenase activity (Soffientino)}

Because the liquid scintillation counter malfunctioned soon after departing Apia, only partial results of Sites SPG-1-SPG-7 were obtained. The radiolabeled slurries from all sites were shipped frozen to URI for postexpedition processing and analysis.

\section{Microbiology (Durbin, Forschner, Harrison, Horn, Kallmeyer, Lever, Puschell, Smith)}

\section{Microscopic results (Kallmeyer)}

Cores from Sites SPG-2-SPG-11 show a rather uniform pattern, with cell abundances of $7 \times 10^{5}$ to $4 \times$ $10^{6}$ cells $/ \mathrm{cm}^{3}$ at the sediment/water interface, dropping steeply by about two orders of magnitude in the upper $0.5 \mathrm{~m}$, and staying almost constant downcore (Fig. F34A, F34B) (D'Hondt et al., 2009). At these sites, surface water concentrations were $\sim 10^{5}$ cells $/ \mathrm{cm}^{3}$ and bottom water concentrations were $10^{4}-10^{5}$ cells $/ \mathrm{cm}^{3}$.

Cell counts at Site SPG-1 appeared slightly elevated relative to some of the other sites but exhibited large shifts between adjacent samples, indicating that the efficiency of the cell separation varied between samples. Therefore, cell separation on Site SPG-1 samples was repeated postcruise.

At Site SPG-12, cell numbers were higher and the distribution was completely different than at all other sites (D'Hondt et al., 2009). At the sediment/water interface, cell abundances were $1 \times 10^{6} \mathrm{cells} / \mathrm{cm}^{3}$, basically in the same range as other cores but not higher. However, at this site no multicorer samples were recovered and the uppermost gravity core sample may not represent the sediment/water interface; possibly a few centimeters of the shallowest sediment were lost. Highest cell abundances $\left(2 \times 10^{6}\right.$ cells $/ \mathrm{cm}^{3}$ ) were found at $\sim 1 \mathrm{mbsf}$. This subsurface maximum in cell density corresponds with the depth at which oxygen is depleted. Below this depth, cell numbers decline steadily to $2 \times 10^{5}$ cells $/ \mathrm{cm}^{3}$ at 5 mbsf. These subseafloor cell numbers are about two orders of magnitude higher than at the other sites. The surface water cell concentration at this site was also higher than at the other sites (slightly above $10^{6}$ cells $/ \mathrm{cm}^{3}$ ).

These shipboard counts show that there is a microbial community in these sediments. Cell abundances at Sites SPG-1-SPG-11 are the lowest ever encountered in the marine environment. Compared to cell counts on samples from Ocean Drilling Program
(ODP) cruises, the cell abundances found in cores from this cruise are on average two orders of magnitude lower. The exception occurs at Site SPG-12, which has cell counts at the lower end of the ODP counts (Fig. F35).

The cell counts of all the field samples were well above the counts for the blank samples. Usually 0 or 1 cell in 400 fields of view at $63 \times$ magnification was found in a blank sample, with 4 cells being the highest count in a blank. These cell counts correspond to cell densities of $7 \times 10^{1}$ to $3 \times 10^{2}$ cells $/ \mathrm{cm}^{3}$. However, the lowest actual cell counts $\left(\sim 1 \times 10^{3}\right.$ cells $\left./ \mathrm{cm}^{3}\right)$ revealed $<10$ cells in 200 fields of view; therefore, these data are statistically much less well constrained as those from samples with higher cell abundances. Further counting postcruise will be necessary to validate these numbers.

\section{Molecular biology (Durbin, Lever)}

In shipboard tests on fresh sediments, archaeal DNA, extracted from the upper meter of sediment from six stations, was uniformly below the detection limit of PCR assays with general archaeal primers (40 cycles amplification +40 cycles reamplification). Further nucleic acid extractions were attempted postcruise (Durbin and Teske, 2010).

\section{Cultures (Forschner, Puschell)}

No contaminants have been detected in the cultures of A. Puschell. There was no detectable shipboard growth in those cultures, except in the media for heterotrophs at Sites SPG-1 and SPG-2 where the lowest dilution $\left(10^{-1}\right)$ appeared to have a hazy film over the sediment, which could be an indicator of growth. The enrichment cultures by G. Horn also did not show strong growth during the expedition. Two of the FeS gradient tubes exhibited haziness in the upper portion of the plug that may indicate growth. The remaining gradient tube cultures did not show signs of growth during the expedition.

Gram-positive bacterial cultivations resulted in growth barely visible to the naked eye. Out of 855 plates inoculated, only 10 showed visible growth during the expedition. All 10 were plated within the first week of sampling and took 4 weeks for growth to appear. Plates continued to be incubated postexpedition at $4^{\circ} \mathrm{C}$. Further studies, including investigations into bioactive metabolites, will commence once pure cultures have been isolated.

\section{References}

Berelson, W.M., Hammond, D.E., and Cutter, G.A., 1990. In situ measurements of calcium carbonate dissolution 
rates in deep-sea sediments. Geochim. Cosmochim. Acta, 54(11):3013-3020. doi:10.1016/0016-7037(90)90118-5

Blair, C.C., D'Hondt, S., Spivack, A.J., and Kingsley, R.H., 2007. Radiolytic hydrogen and microbial respiration in subsurface sediments. Astrobiology, 7(6):951-970. doi:10.1089/ast.2007.0150

D'Hondt, S., Abrams, L.J., Pockalny, R.A., Spivack A.J., and Teske, A.P., 2006. Subseafloor exploration in the central South Pacific. Astrobiology, 6(1):201.

D'Hondt, S., Jørgensen, B.B., Miller, D.J., Batzke, A., Blake, R., Cragg, B.A., Cypionka, H., Dickens, G.R., Ferdelman, T., Hinrichs, K.-U., Holm, N.G., Mitterer, R., Spivack, A., Wang, G., Bekins, B., Engelen, B., Ford, K., Gettemy, G., Rutherford, S.D., Sass, H., Skilbeck, C.G., Aiello, I.W., Guerin, G., House, C.H., Inagaki, F., Meister, P., Naehr, T., Niitsuma, S., Parkes, R.J., Schippers, A., Smith, D.C., Teske, A., Wiegel, J., Naranjo Padillo, C., and Solis Acosta, J.L., 2004. Distributions of microbial activities in deep subseafloor sediments. Science, 306(5705):22162221. doi:10.1126/science.1101155

D'Hondt, S., Rutherford, S., and Spivack., A.J., 2002. Metabolic activity of the subsurface life in deep-sea sediments. Science, 295(5562):2067-2070. doi:10.1126/ science. 1064878

D’Hondt, S., Spivack, A.J., Pockalny, R., Ferdelman, T.G., Fischer, J.P., Kallmeyer, J., Abrams, L.J., Smith, D.C., Graham, D., Hasiuk, F., Schrum, H., and Stancine, A.M., 2009. Subseafloor sedimentary life in the South Pacific Gyre. Proc. Natl. Acad. Sci. U. S. A., 106(28):1165111656. doi:10.1073/pnas.0811793106

Durbin, A.M., and Teske, A., 2010. Sediment-associated microdiversity within the Marine Group I Crenarchaeota. Environ. Microbiol. Rep., 2(5):693-703. doi:10.1111/j.1758-2229.2010.00163.x

Emerson, D., and Floyd, M.M., 2005. Enrichment and isolation of iron-oxidizing bacteria at neutral $\mathrm{pH}$. Methods Enzymol., 397:112-123. doi:10.1016/S00766879(05) 97006-7

Fischer, J.P., Ferdelman, T.G., D'Hondt, S., Røy, H., and Wenzhöfer, F., 2009. Oxygen penetration deep into the sediment of the South Pacific Gyre. Biogeosciences, 6:1467-1478. http://www.biogeosciences.net/6/ 1467/2009/bg-6-1467-2009.pdf

Gieskes, J.M., Gamo, T., and Brumsack, H., 1991. Chemical methods for interstitial water analysis aboard JOIDES Resolution. ODP Tech. Note, 15. doi:10.2973/ odp.tn.15.1991

Halm, H., Lam, P., Ferdelman, T.G., Lavik, G., Dittmar, T., LaRoche, J., D'Hondt, S., and Kuypers, M.M.M., submitted. Heterotrophic organisms dominate nitrogen fixation in the South Pacific Gyre. ISME J.

Harris R.N., Fisher, A.T., and Chapman, D.S., 2004. Fluid flow through seamounts and implications for global mass fluxes. Geology, 32(8):725-728. doi:10.1130/ G20387.1

Hoehler, T.M., Alperin, M.J., Albert, D.B., and Martens, C.S., 1998. Thermodynamic control on hydrogen concentrations in anoxic sediments. Geochim. Cosmochim. Acta, 62(10):1745-1756. doi:10.1016/S00167037(98)00106-9
Jahnke, R.A., 1996. The global ocean flux of particulate organic carbon: areal distribution and magnitude. Global Biogeochem. Cycles, 10(1):71-88. doi:10.1029/ 95GB03525

Jørgensen, B.B., and D'Hondt, S., 2006. A starving majority deep beneath the seafloor. Science, 314(5801):932-943. doi:10.1126/science.1133796

Kallmeyer, J., Pockalny, R.A., D'Hondt, S.L., and Adhikari, R.R., 2009. A new estimate of total microbial subseafloor biomass. Eos, Trans. Am. Geophys. Union, 90(52)(Suppl.):B23C-0381. (Abstract) http:// www.agu.org/meetings/fm09/waisfm09.html

Kallmeyer, J., Smith, D.C., Spivack, A.J., and D'Hondt, S., 2008. New cell extraction procedure applied to deep subsurface sediments. Limnol. Oceanogr.: Methods, 6:236-245. doi:10.4319/lom.2008.6.236

Klimant, I., Meyer, V., and Kühl, M., 1995. Fiber-optic oxygen microsensors, a new tool in aquatic biology. Limnol. Oceanogr., 40(6):1159-1165. doi:10.4319/ lo.1995.40.6.1159

McNutt, M.K., 1998. Superswells. Rev. Geophys., 36(2):211244. doi:10.1029/98RG00255

Morel, A., Gentili, B., Claustre, H., Babin, M., Bricaud, A., Ras, J., and Tiéche, F., 2007. Optical properties of the "clearest" natural waters. Limnol. Oceanogr., 52(1):217229. http://www.aslo.org/lo/toc/vol_52/issue_1/ 0217.pdf

Parkes, R.J., Cragg, B.A., and Wellsbury, P., 2000. Recent studies on bacterial populations and processes in subseafloor sediments: a review. Hydrogeol. J., 8(1):11-28. doi:10.1007/PL00010971

Pfender, M., and Villinger, H., 2002. Miniaturized data loggers for deep sea sediment temperature gradient measurements. Mar. Geol., 186(3-4):557-570. doi:10.1016/ S0025-3227(02)00213-X

Revsbech, N.P., and Jørgensen, B.B., 1986. Microelectrodes: their use in microbial ecology. Adv. Microb. Ecol., 9:293352. http://www.mbl.ku.dk/mkuhl/nordforsk2006/ advances063.pdf

Smith, W.H.F., and Sandwell, D.T., 1997. Global sea floor topography from satellite altimetry and ship depth soundings. Science, 277(5334):1956-1962. doi:10.1126/ science.277.5334.1956

Soffientino, B., Spivack, A.J., Smith, D.C., Roggenstein, E.B., and $\mathrm{D}^{\prime}$ Hondt, S., 2006. A versatile and sensitive tritium-based radioassay for measuring hydrogenase activity in aquatic sediments. J. Microbiol. Methods, 66(1):136-146. doi:10.1016/j.mimet.2005.11.004

Stein, C.A., and Abbot, D.H., 1991. Heat flow constraints on the South Pacific Superswell. J. Geophys. Res., [Solid Earth], 96(B10):16083-16099. doi:10.1029/91JB00774

Stein, C.A., and Stein, S., 1992. A model for the global variation in oceanic depth and heat flow with lithospheric age. Nature (London, U. K.), 359(6391):123-129. doi:10.1038/359123a0

Teske, A., Brinkhoff, T., Muyzer, G., Moser, D.P., Rethmeier, J., and Jannasch, H.W., 2000. Diversity of thiosulfateoxidizing bacteria from marine sediments and hydrothermal vents. Appl. Environ. Microbiol., 66(8):31253133. doi:10.1128/AEM.66.8.3125-3133.2000 
Wang, G., Spivack, A.J., D'Hondt, S., Rutherford, S., and Manor, U., 2004. Metabolic activity in deep-sea sediment columns. Int. J. Astrobiol., 2004(Suppl.):70.

Wessel, P., 2001. Global distribution of seamounts inferred from gridded Geosat/ERS-1 altimetry. J. Geophys. Res., [Solid Earth], 106(B9):19431-19441. doi:10.1029/ 2000JB000083
Whitman, W.B., Coleman, D.C., and Wiebe, W.J., 1998. Prokaryotes: the unseen majority. Proc. Natl. Acad. Sci. U. S. A., 95(12):6578-6583. doi:10.1073/ pnas.95.12.6578

Publication: 13 December 2011 MS 329-112 
Figure F1. Cruise KNOX-02RR site locations (numbered circles). White lines = basement isochrons (in Ma), black lines = backtrack positions for Sites SPG-1 and SPG-12.

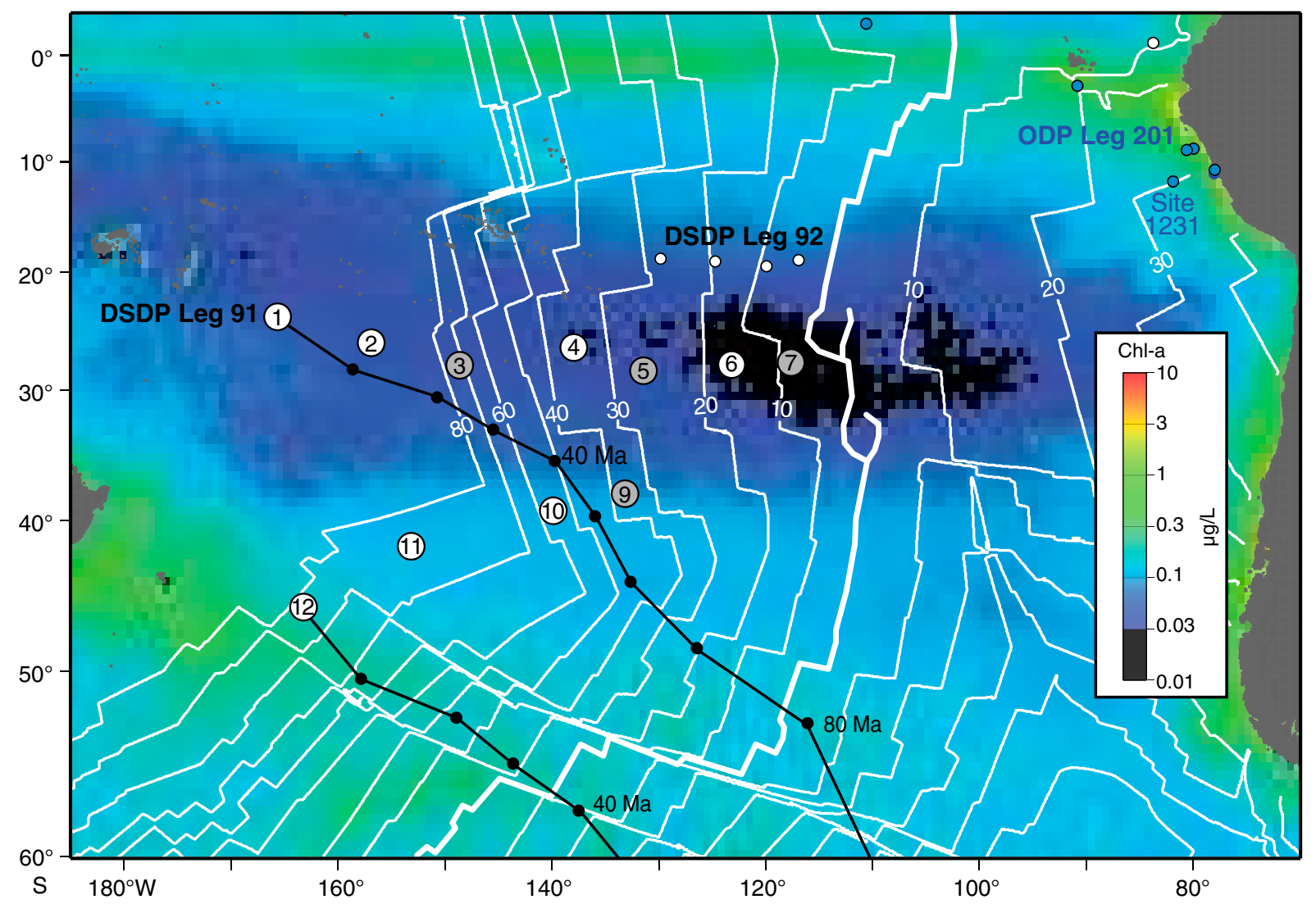


Figure F2. Seafloor bathymetry of the South Pacific Gyre (Smith and Sandwell, 1997). Yellow circles indicate coring sites with associated crustal ages in Ma. Magnetic lineations are shown at an interval of 10 Ma. Red circles indicate existing heat flow data.

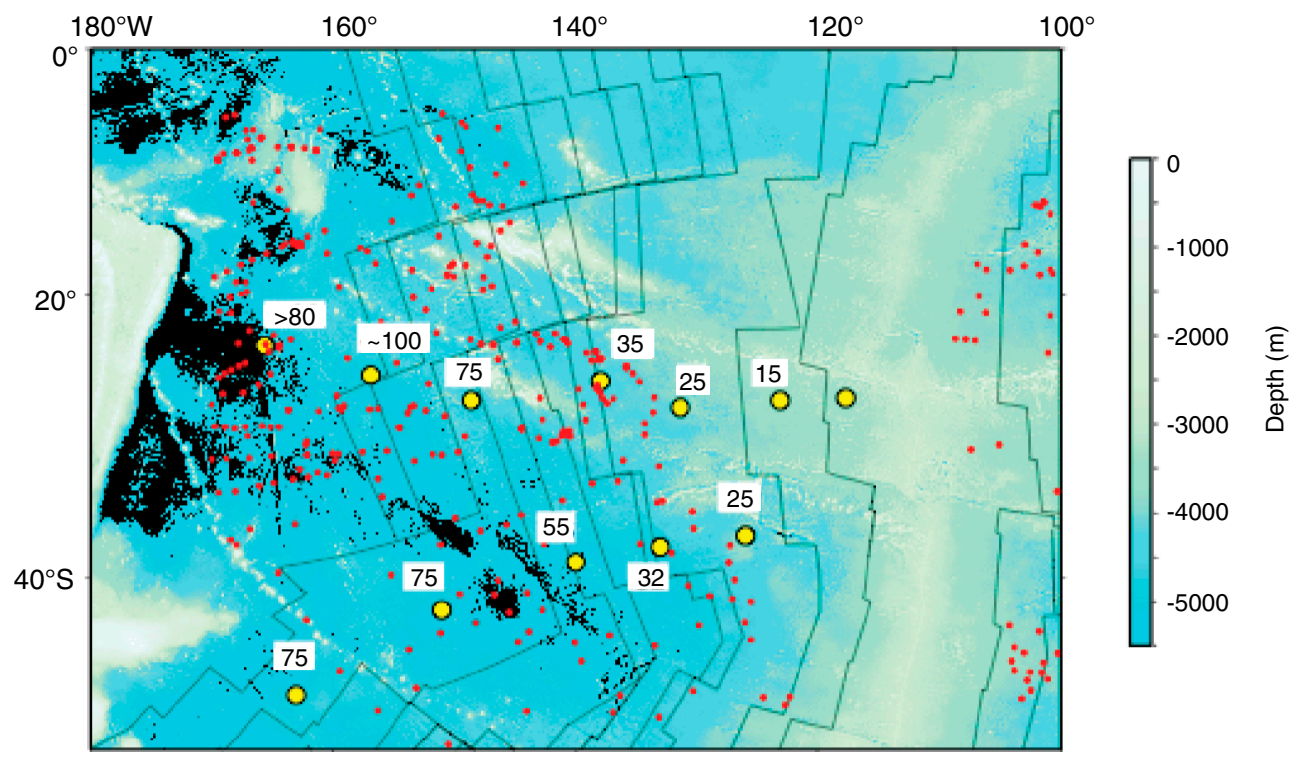


Figure F3. A. Construction sketch of miniaturized temperature data logger. B. Photograph of logger protected in a fin attachment on a core barrel (Pfender and Villinger, 2002). A/D = analog to digital.

A

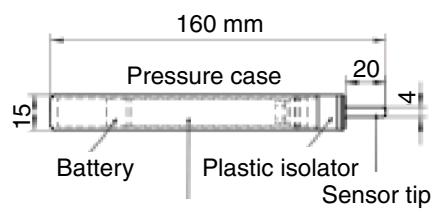

Board with A/D converter, microprocessor

internal clock, and memory

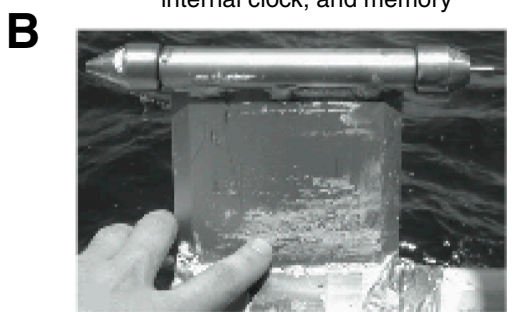


Figure F4. Photograph of fin attachments placed on the core barrel showing both the short and long styles.

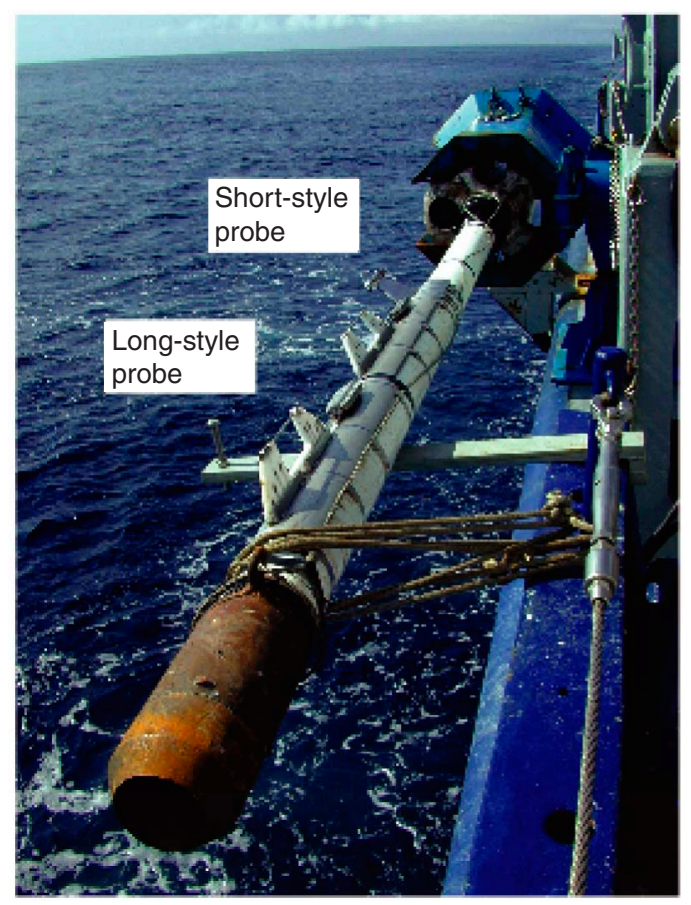


Figure F5. Diagram of section labeling before and after core removal.

Section numbering from the top

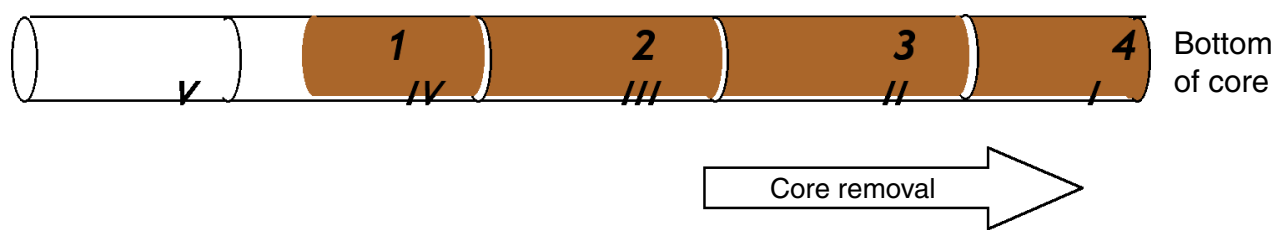


Figure F6. Illustration of intended operation of an Argo float.

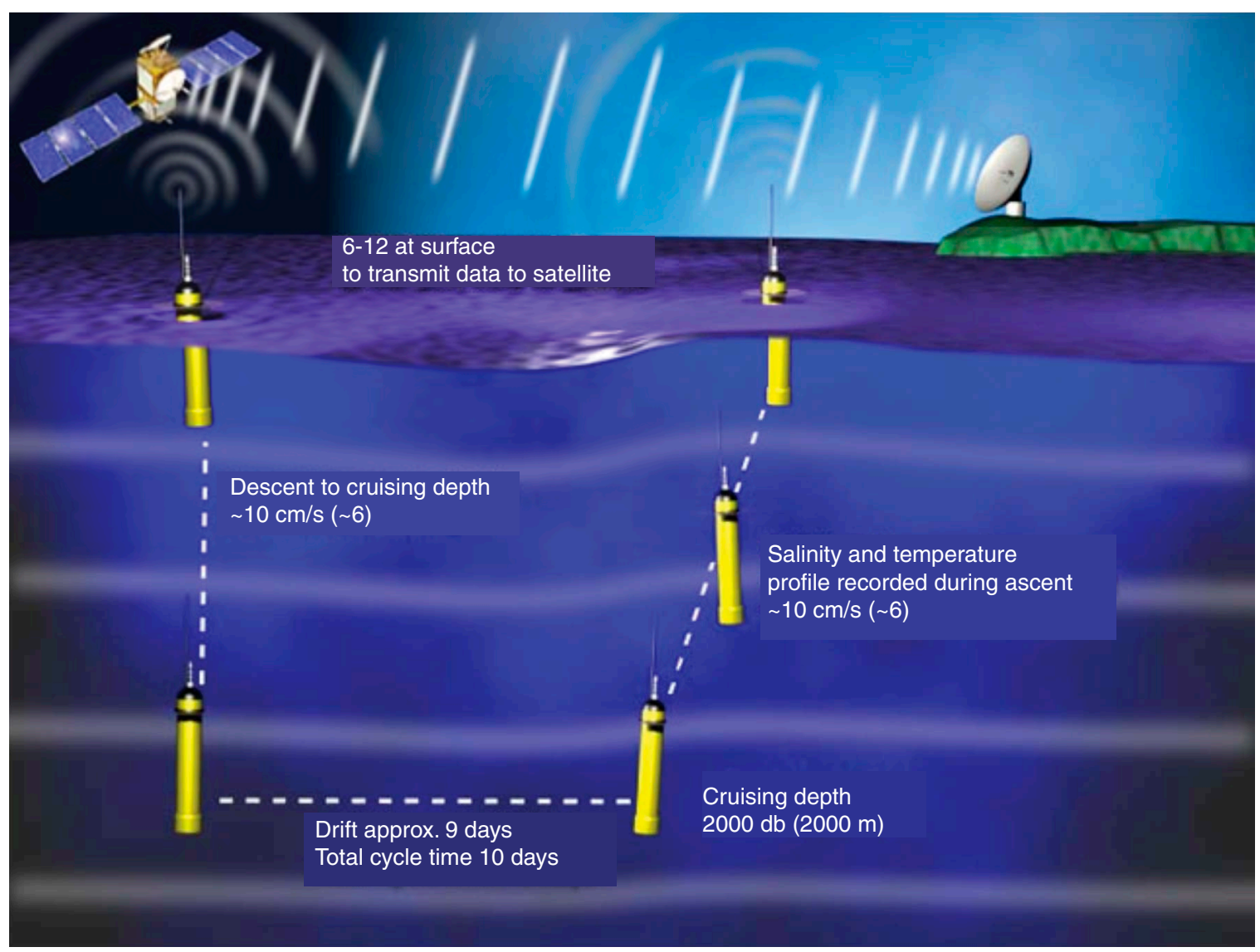


Figure F7. Graph of core recovery for Sites SPG-1-SPG-6. No material was recovered at SPG3-T2.

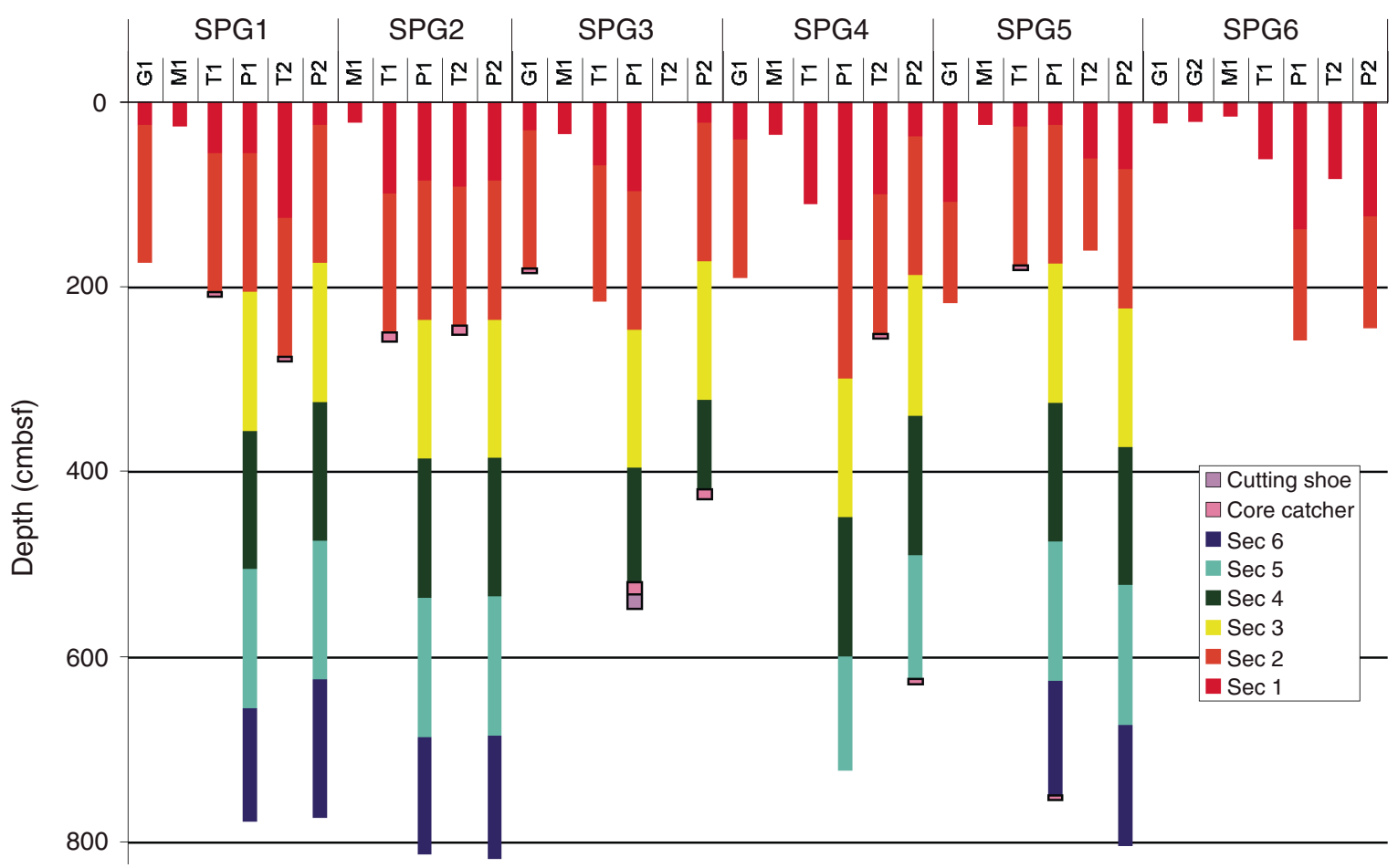


Figure F8. Graph of core recovery for Sites SPG-7-SPG-12. No material was recovered at SPG10-P2, SPG11-P1, or SPG12-M1.

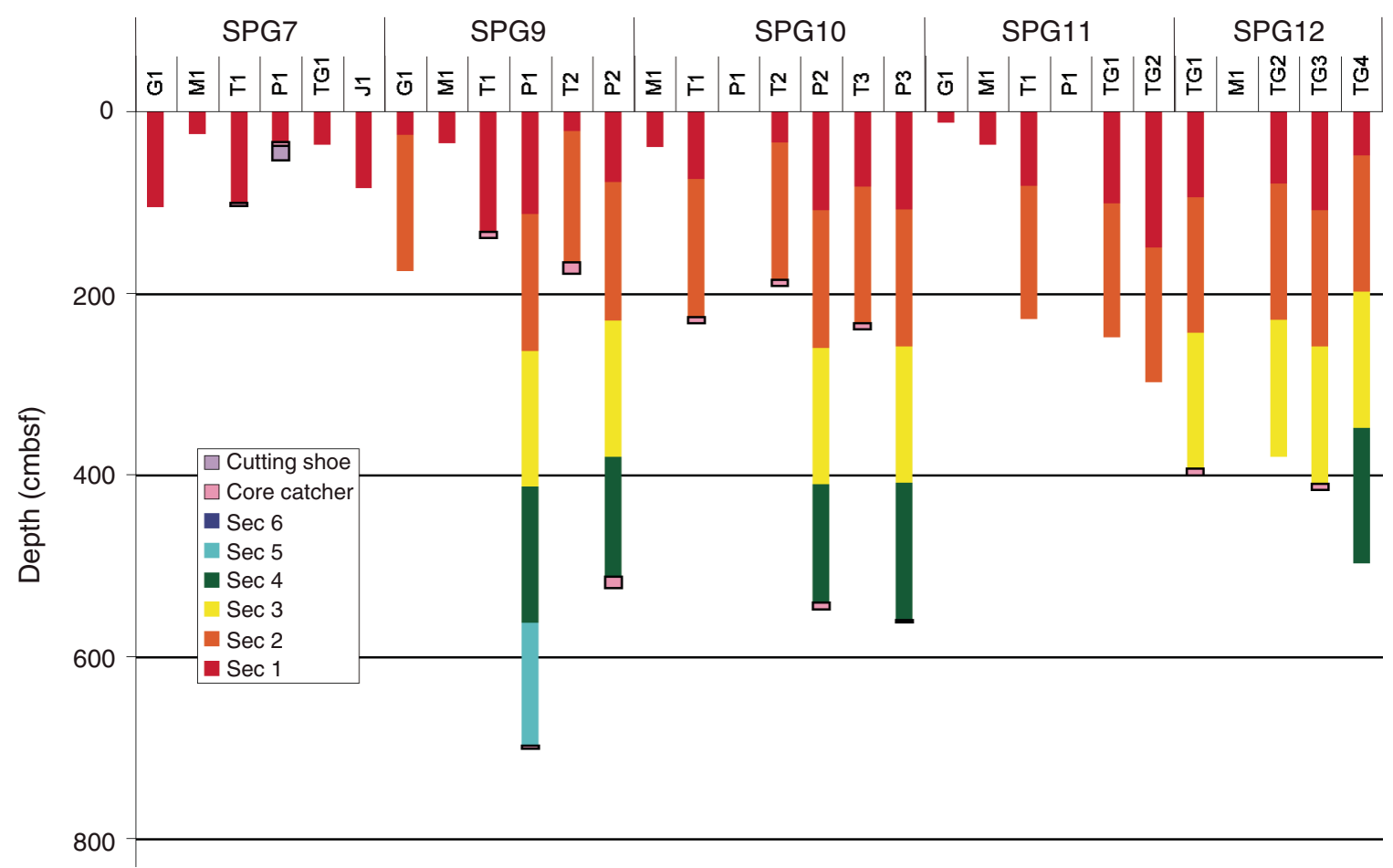


Figure F9. Bathymetry map showing ship track along which underway geophysical data were taken.

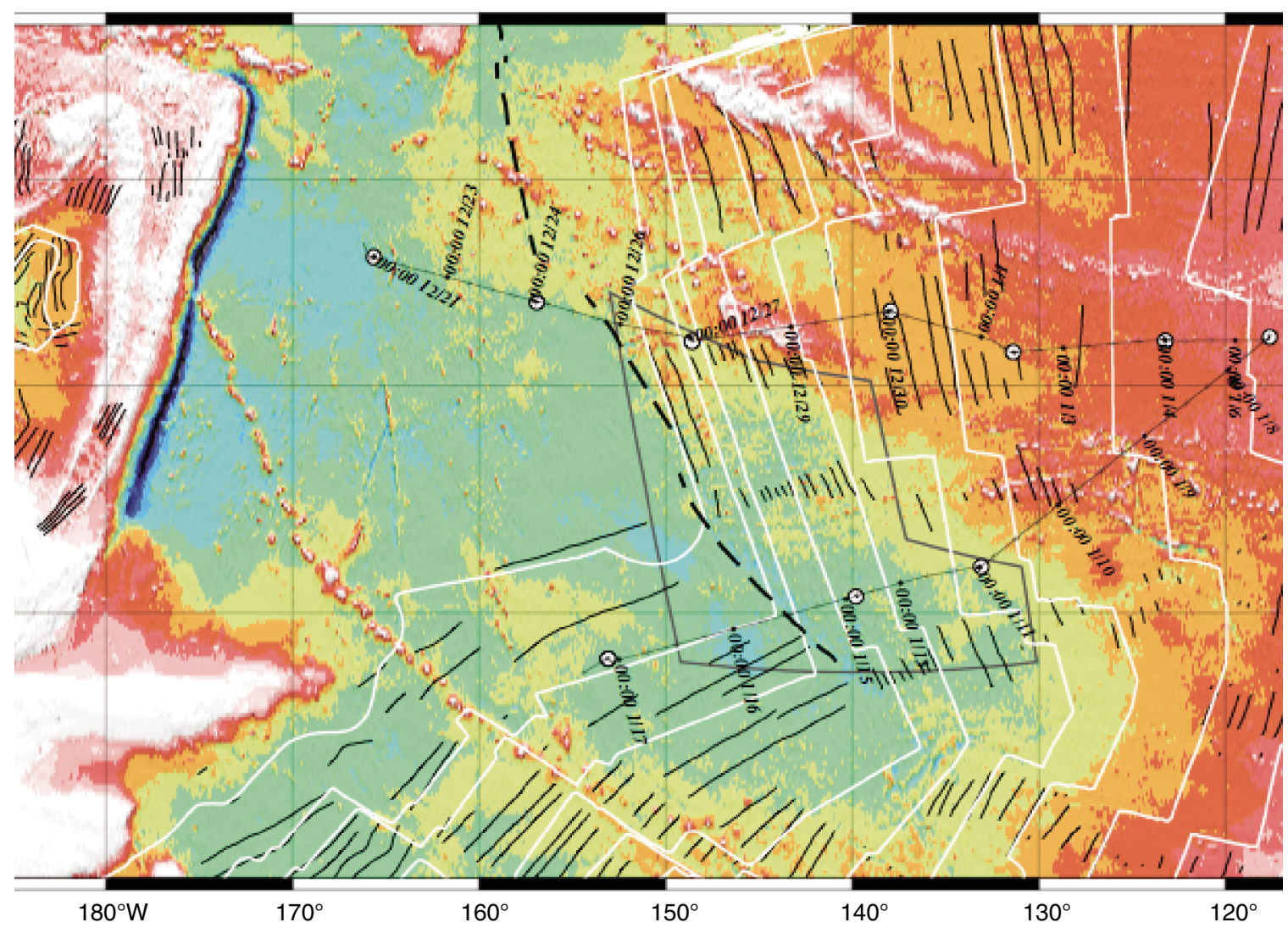


Figure F10. Plot of crust age, spreading rate, and sediment thickness of survey sites. White sediment columns and yellow circles indicate northern transect sites. Green sediment columns and green circles indicate southern transect sites.

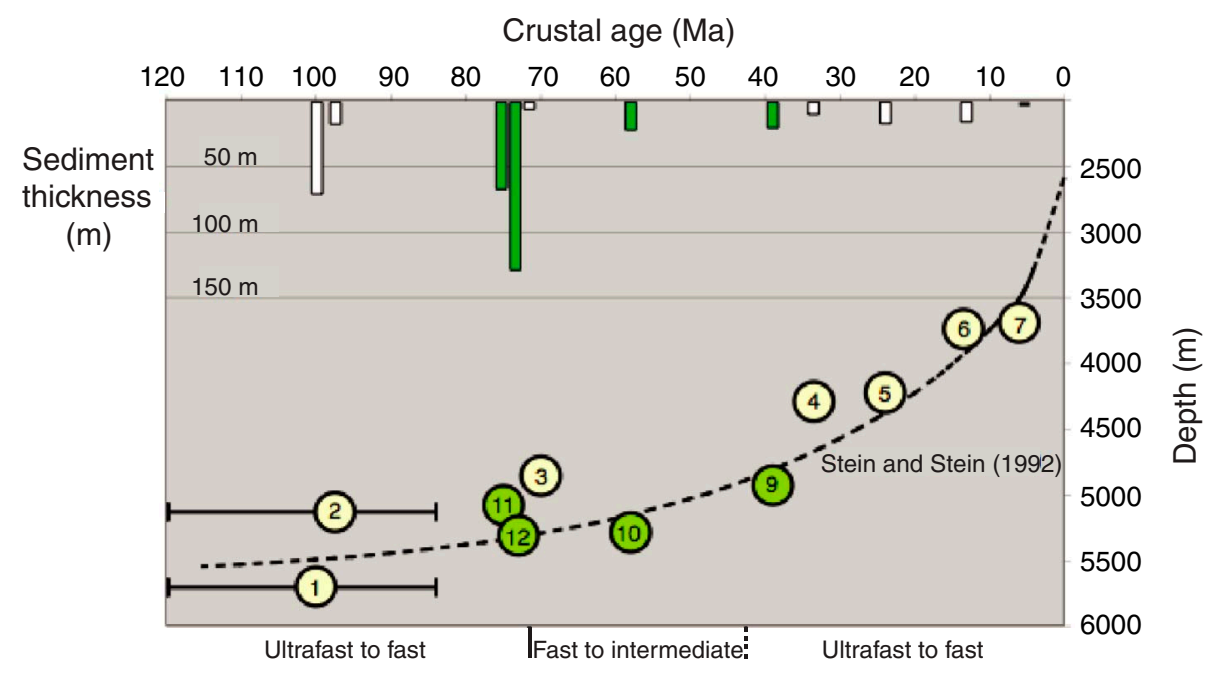


Figure F11. Example of data collected with autonomous outrigger thermistors. Measurement interval is $5 \mathrm{~s}$. The relative temperature value remains constant through penetration for three sediment thermistors and one bottom water thermistor. A. Full temperature series showing temperature on the ship, lowering of the core through the water column, penetration, and recovery. B. Expanded section of thermistor penetration. Initial period of temperature rise and equilibration follows penetration of the seafloor by the probe. The core is left in the sediment for 7 min.

\section{A}

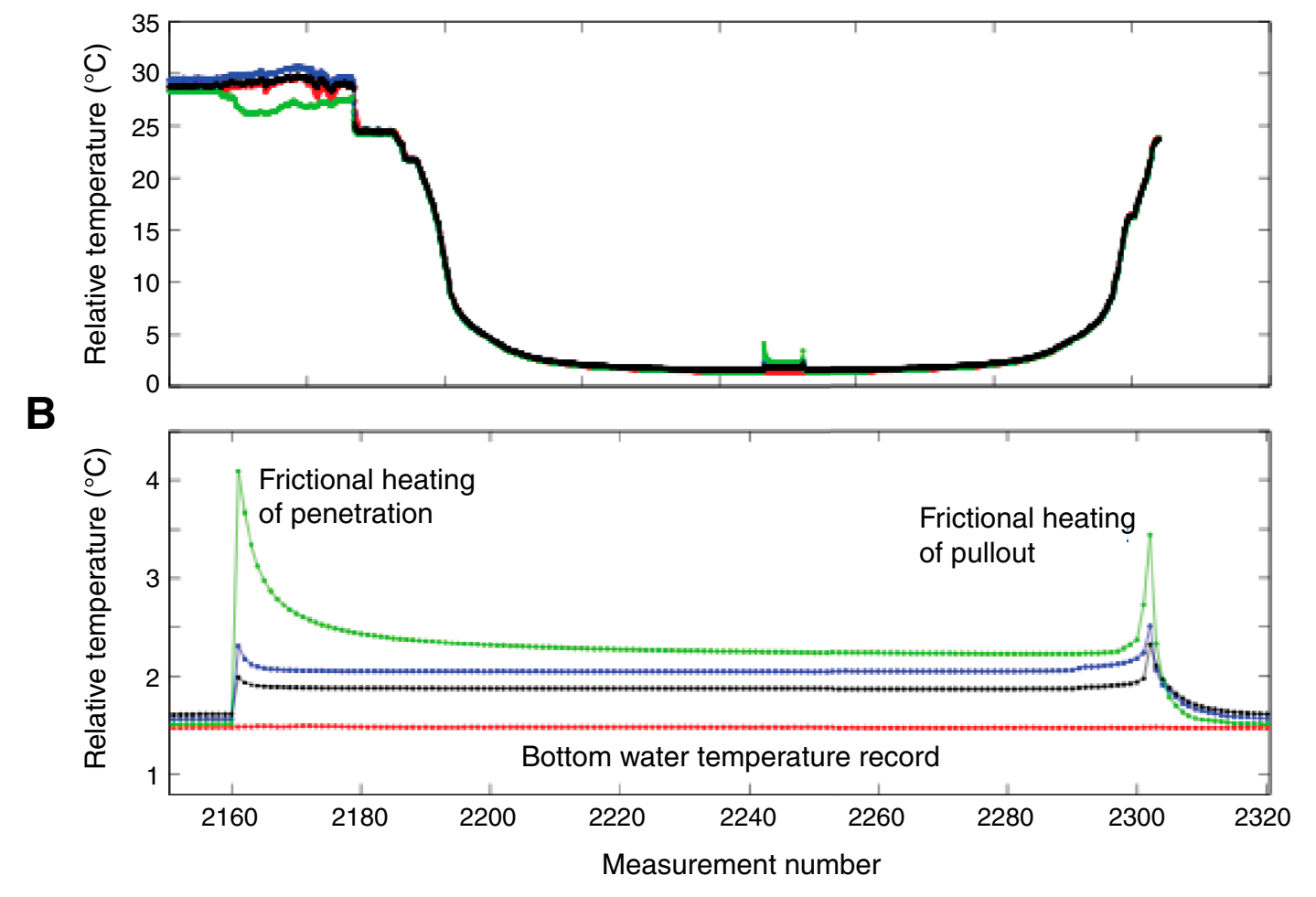


Figure F12. Plots of thermal conductivity values from coring sites. Thermal conductivities were determined with the needle-probe method. Different symbols correspond to different needle probes. k-bar $=$ average thermal conductivity, $\sigma=$ standard deviation. (Continued on next page.)

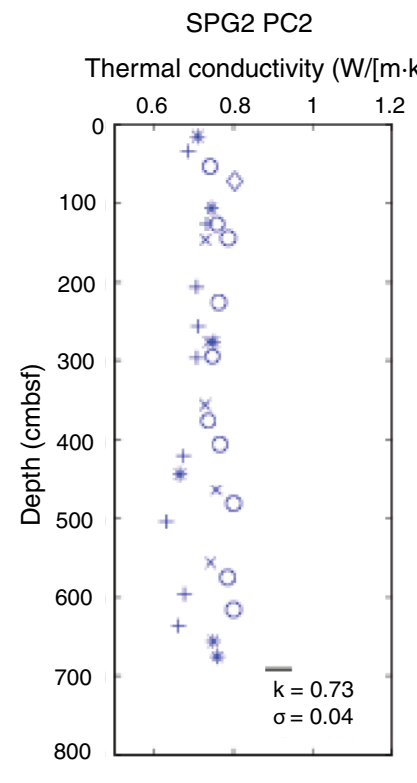

SPG5 PC2

Thermal conductivity $(\mathrm{W} /[\mathrm{m} \cdot \mathrm{k}])$

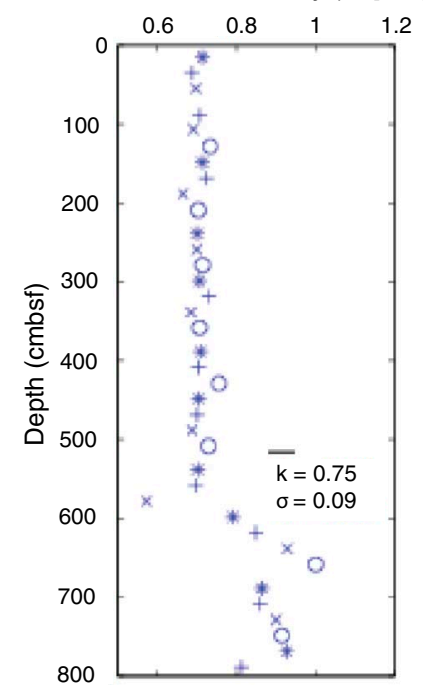

SPG3 PC1

SPG4 PC2

Thermal conductivity $(\mathrm{W} /[\mathrm{m} \cdot \mathrm{k}]) \quad$ Thermal conductivity $(\mathrm{W} /[\mathrm{m} \cdot \mathrm{k}])$

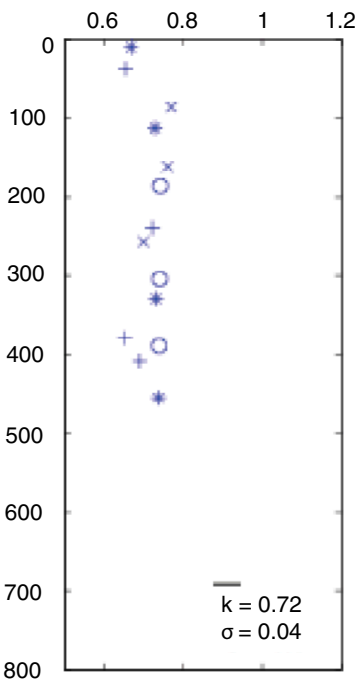

SPG6 PC2

Thermal conductivity $(\mathrm{W} /[\mathrm{m} \cdot \mathrm{k}]) \quad$ Thermal conductivity $(\mathrm{W} /[\mathrm{m} \cdot \mathrm{k}])$

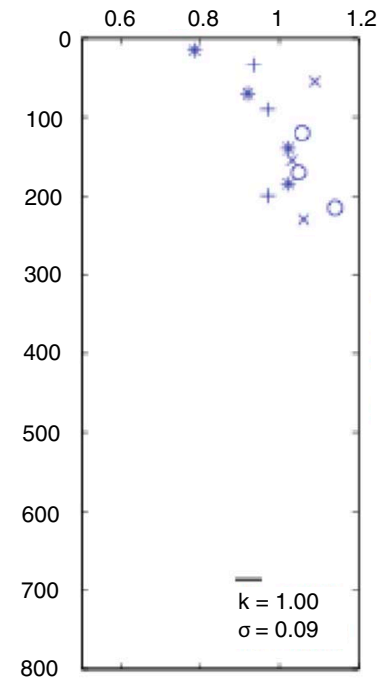

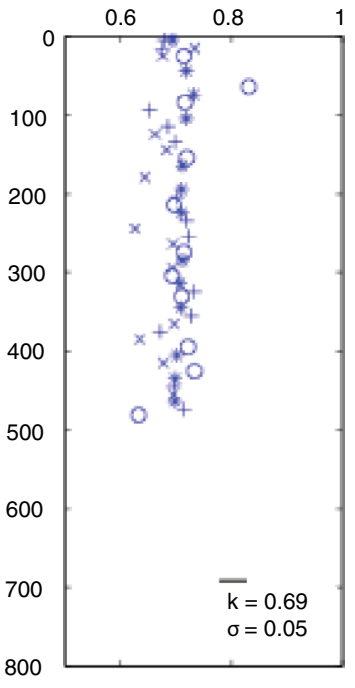

SPG7 JC2

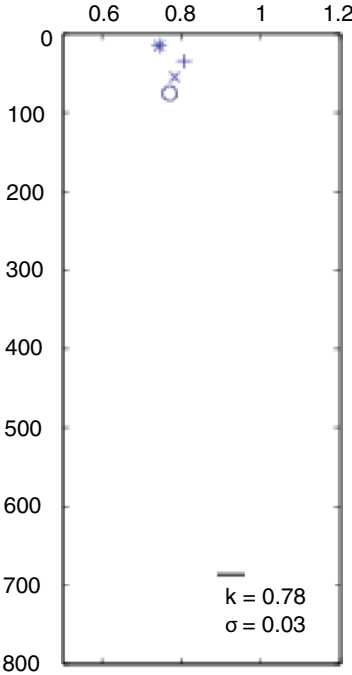


Figure F12 (continued).

SPG9 PC2

Thermal conductivity $(\mathrm{W} /[\mathrm{m} \cdot \mathrm{k}])$

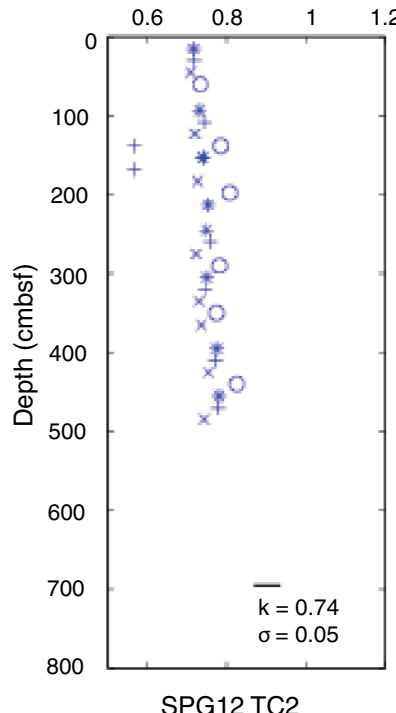

Thermal conductivity $(\mathrm{W} /[\mathrm{m} \cdot \mathrm{k}])$

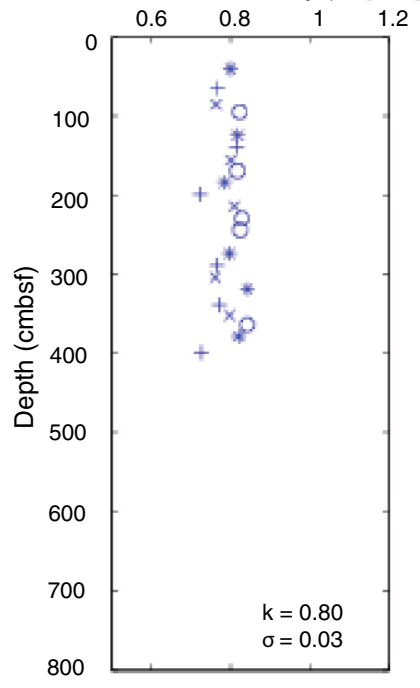

SPG10 PC3

SPG11 TC2

Thermal conductivity $(\mathrm{W} /[\mathrm{m} \cdot \mathrm{k}]) \quad$ Thermal conductivity $(\mathrm{W} /[\mathrm{m} \cdot \mathrm{k}])$

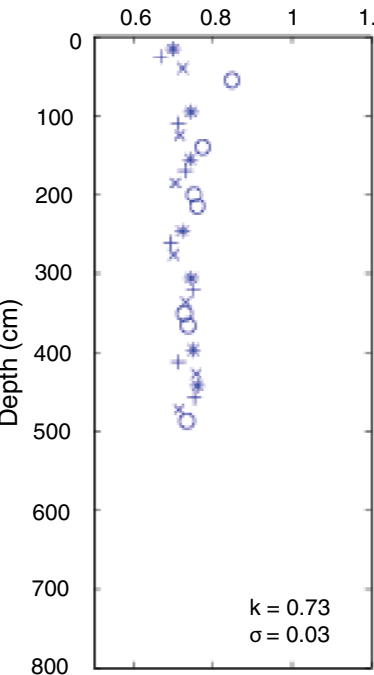

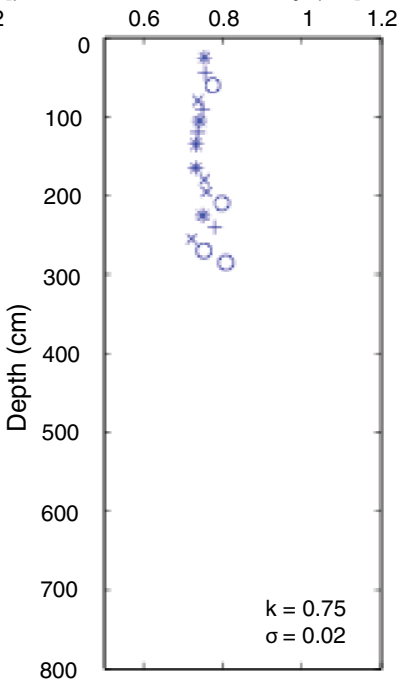

800 
Figure F13. Plot of global marine heat flow compilation of Stein and Stein (1992). Gray circles = heat flow in $2 \mathrm{~m}$.y. bins with standard deviation. Gray line shows best fit model based on global heat flow and bathymetry. Red circles $=$ heat flow values collected at coring sites.

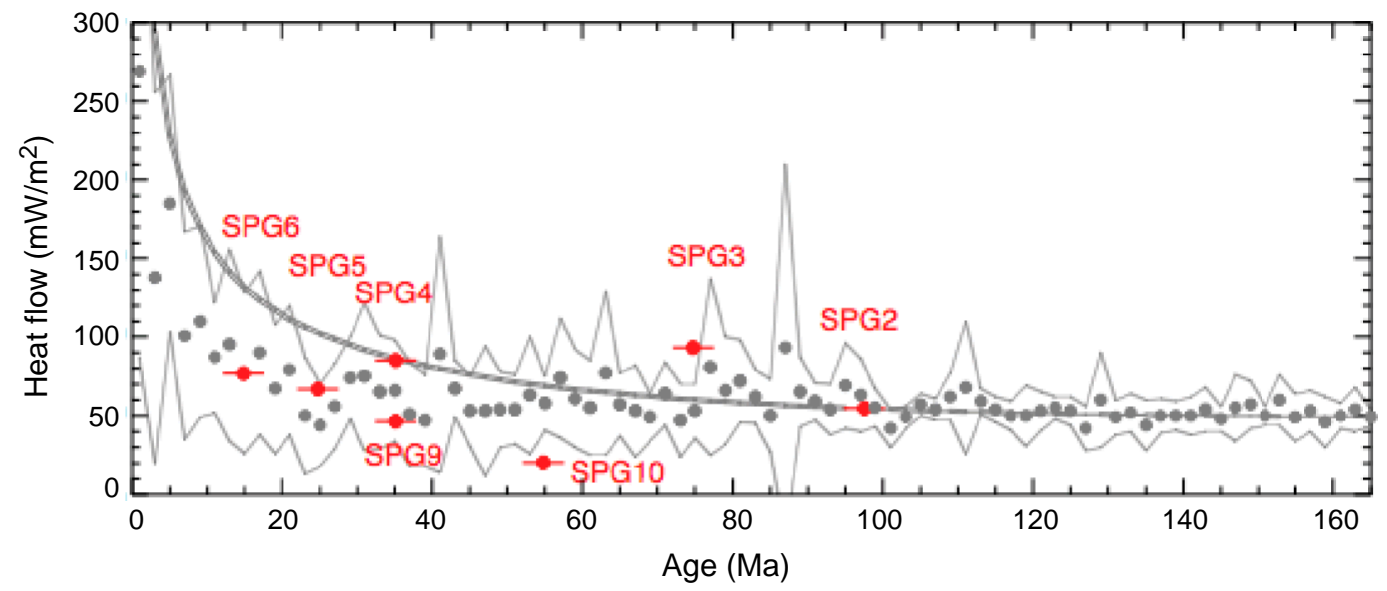


Figure F14. Plots of existing heat flow determinations in the vicinity of Sites SPG1 and SPG4. At both sites, values show variability, which suggests advective fluid flow in the basement. Red " $x$ " indicates observed heat flow at Site SPG4.
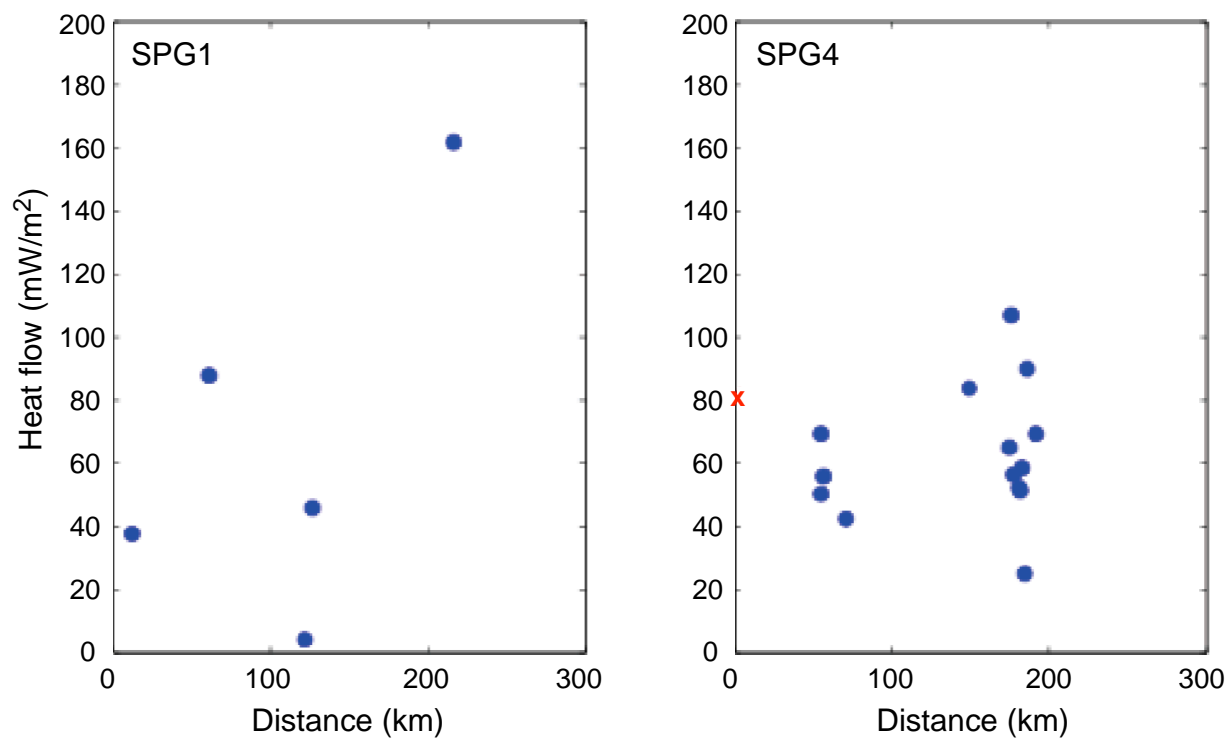
Figure F15. Graph depicting length of section recovered (gold) at each site with respect to the total sedimentary section (blue + gold) at each site.

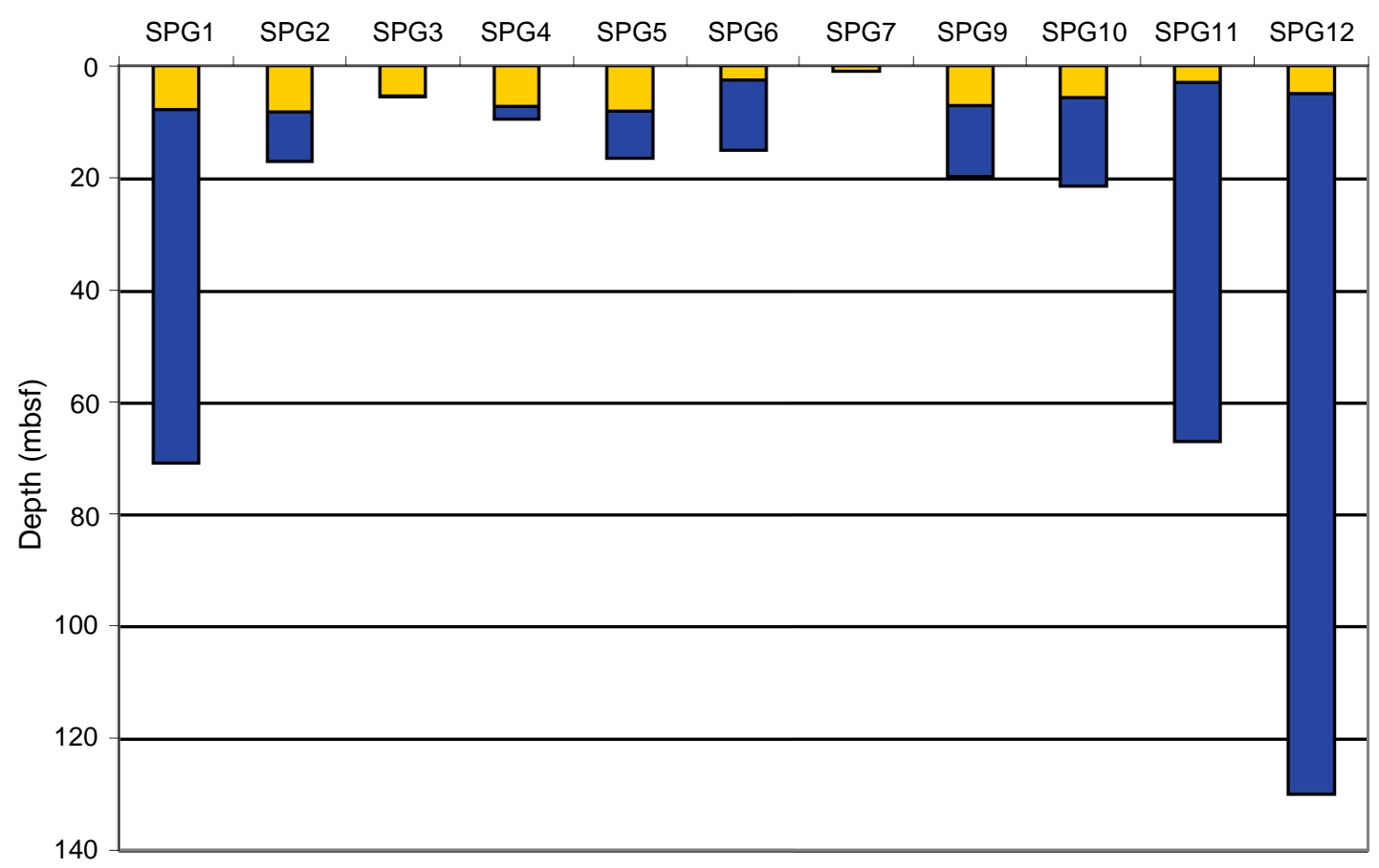


Figure F16. Schematic stratigraphic columns for each site visited. Red-brown = clays, yellow = carbonate ooze, green $=$ siliceous ooze . Solid circles and ovals represent manganese nodules.

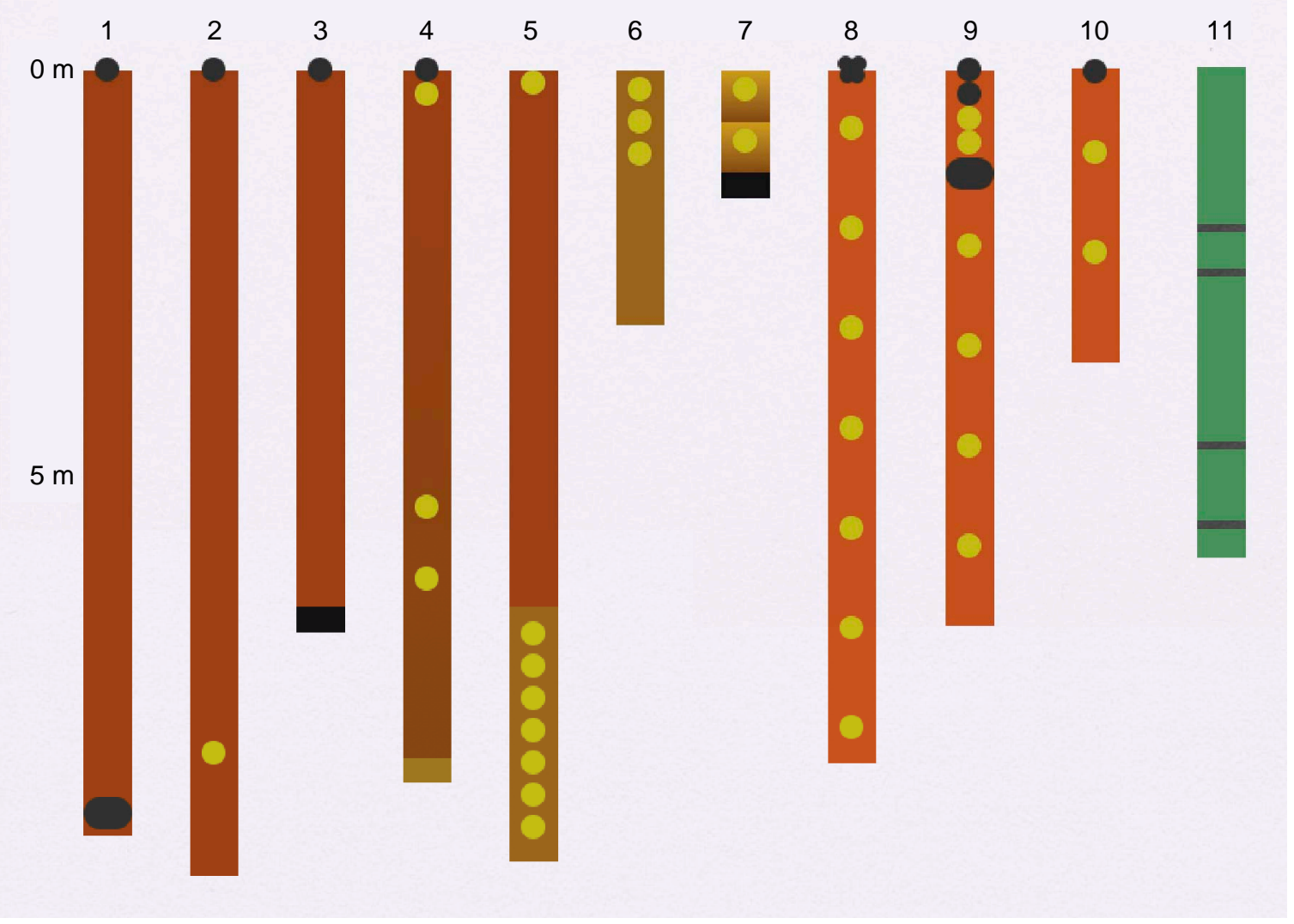


Figure F17. Diagram of vertical sedimentation rates in meters per million years.

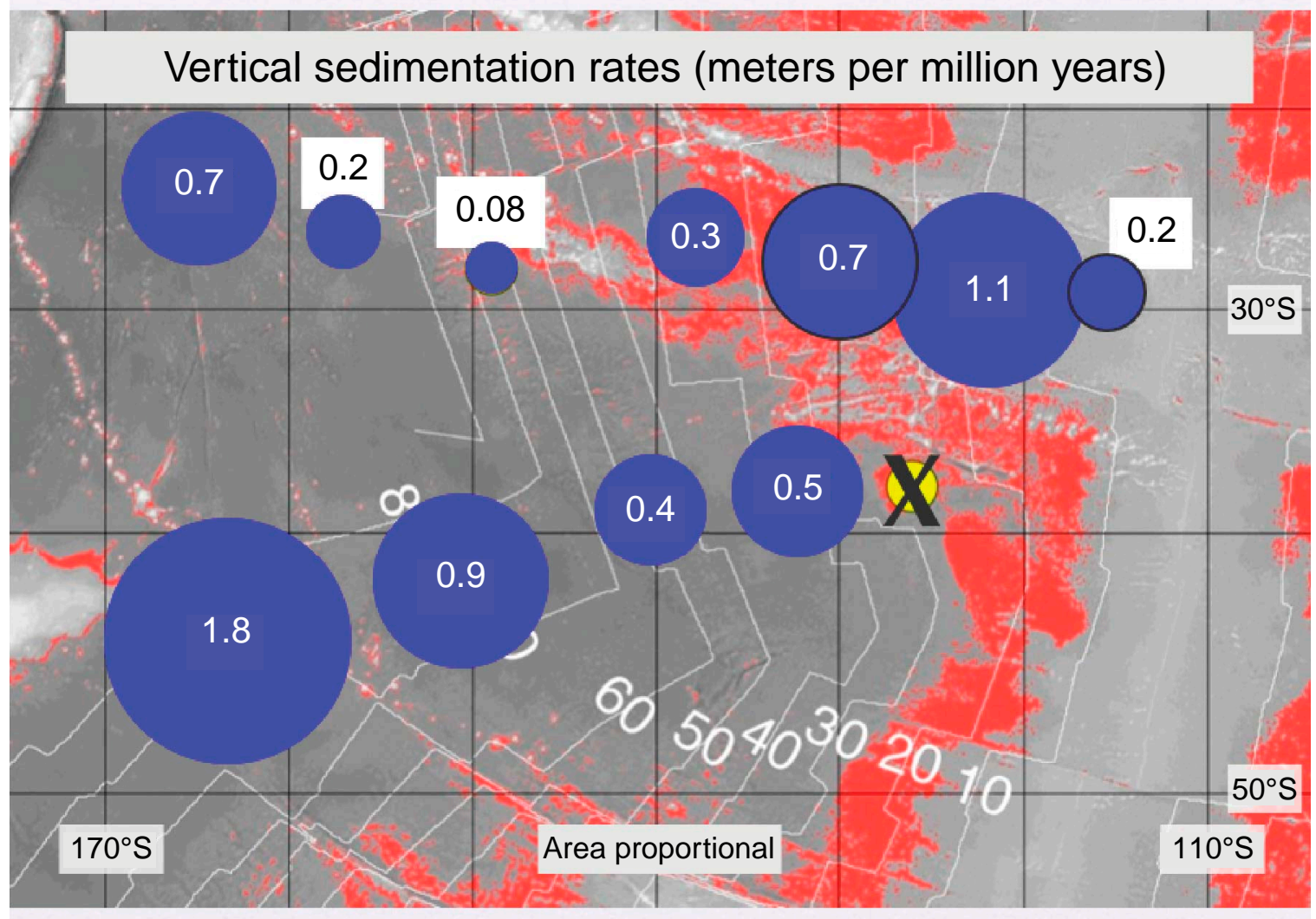


Figure F18. Edited Site SPG-1 core logs. Density is calculated from gamma counts and core thickness. Red = SPG1-P1, green = SPG1-P2, blue = SPG1-M1, cyan = SPG1-T1, black = SPG1-T2.

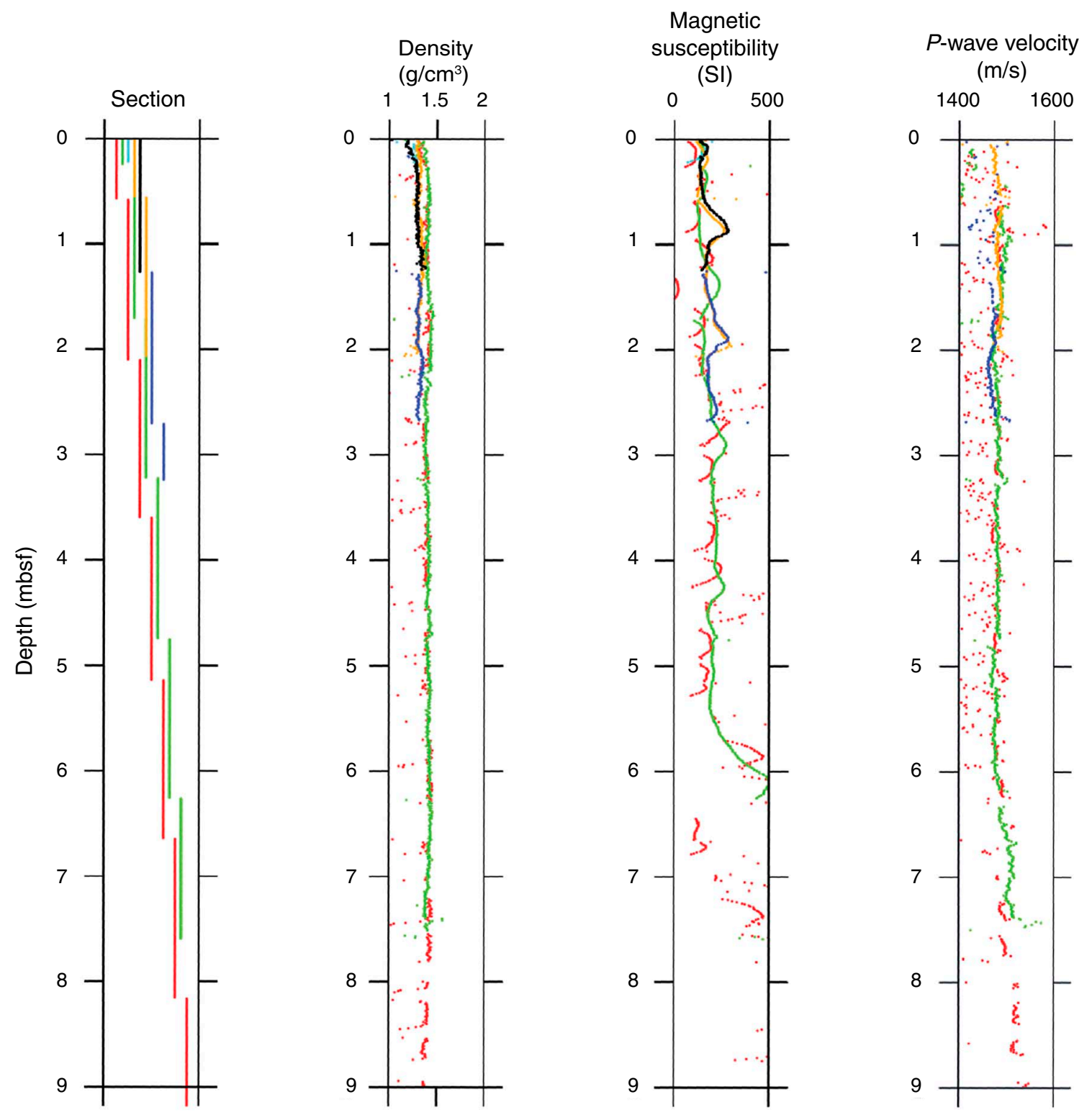


Figure F19. Edited SPG-2 core logs. Density is calculated from gamma counts and core thickness. Red = SPG2$\mathrm{P} 1$, green $=$ SPG2-P2, blue $=$ SPG2-T1, cyan $=$ SPG2-T2 .

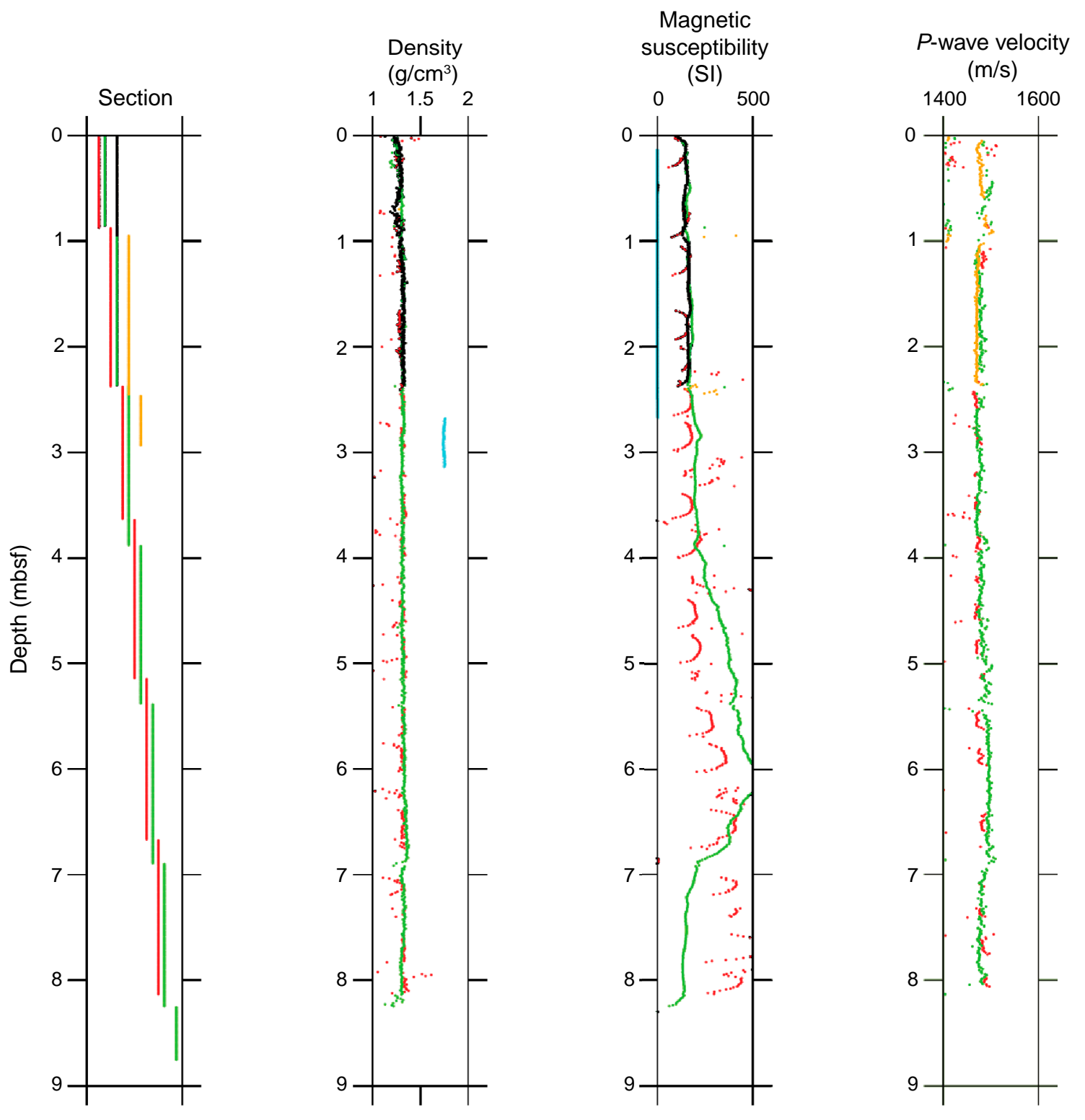


Figure F20. Edited SPG-3 core logs. Density is calculated from gamma counts and core thickness. Red = SPG2$\mathrm{P} 1$, green $=$ SPG2-P2, blue $=$ SPG2-T1 .

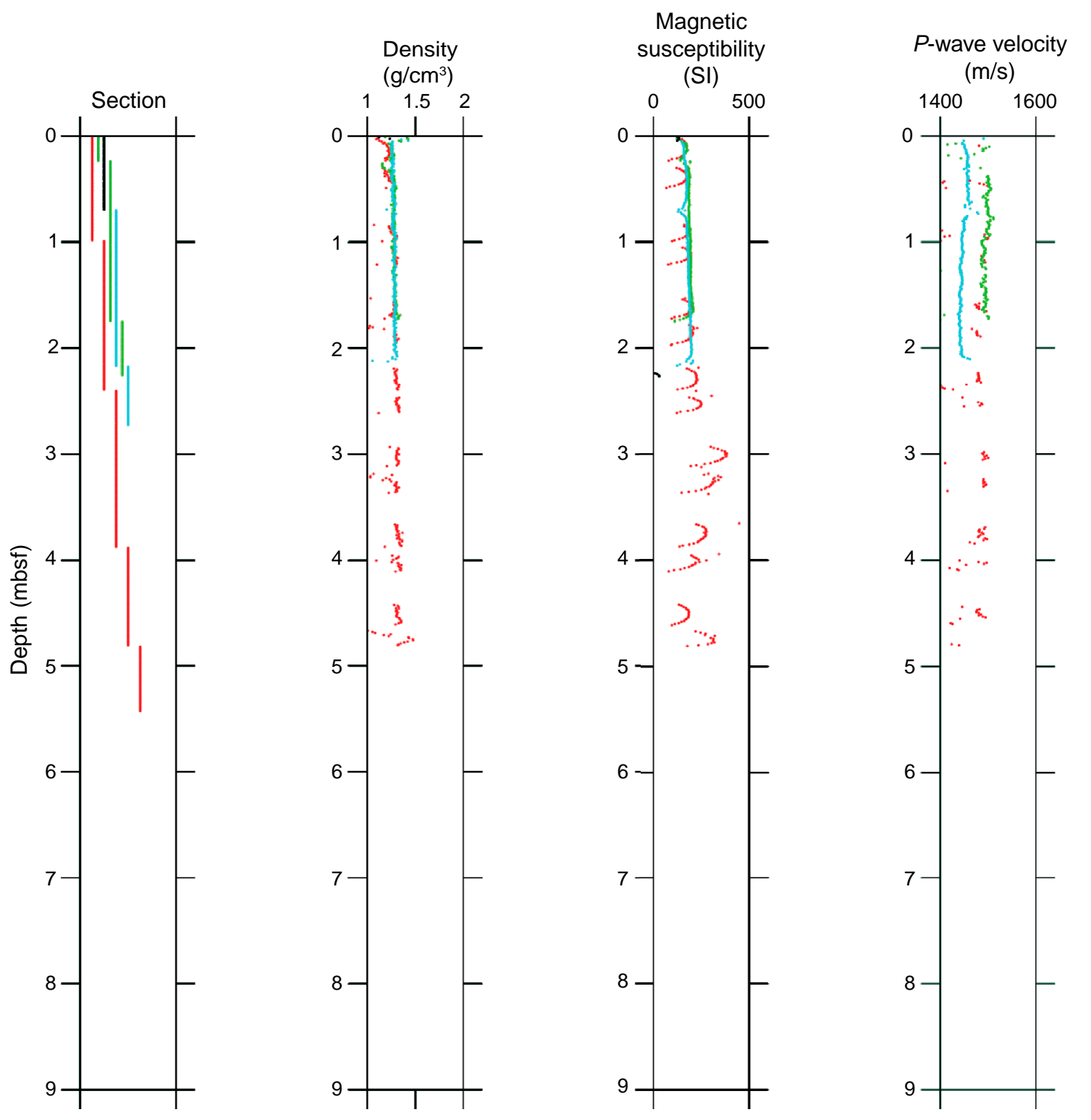


Figure F21. Edited SPG-4 core logs. Density is calculated from gamma counts and core thickness. Red = SPG4P1, green = SPG4-P2, blue = SPG4-M1, cyan = SPG4-T1, black = SPG4-T2.

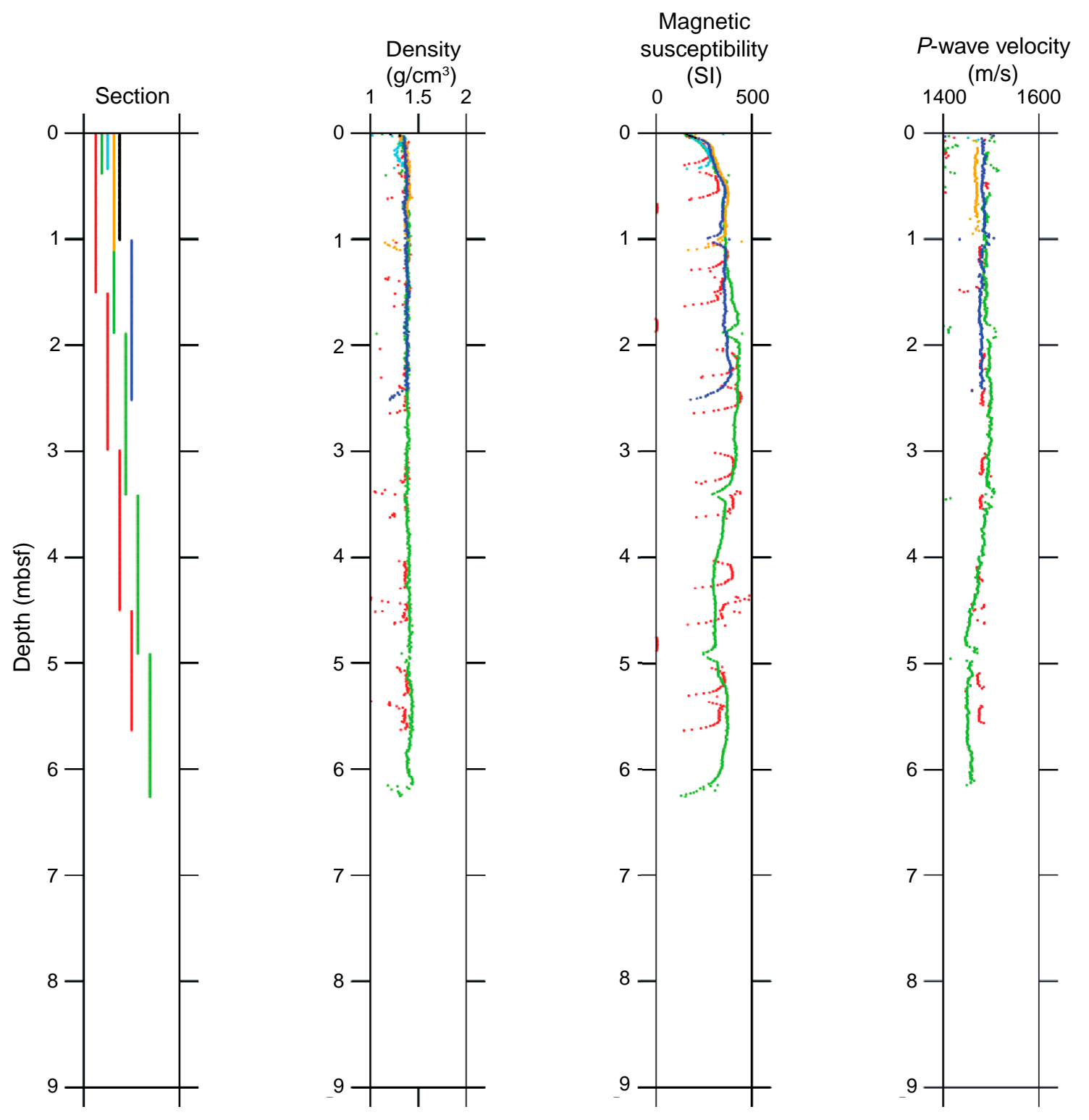


Figure F22. Edited SPG-5 core logs. Density is calculated from gamma counts and core thickness. Red = SPG5$\mathrm{P} 1$, green = SPG5-P2, blue = SPG5-M1, cyan = SPG5-T1, black = SPG5-T2 .

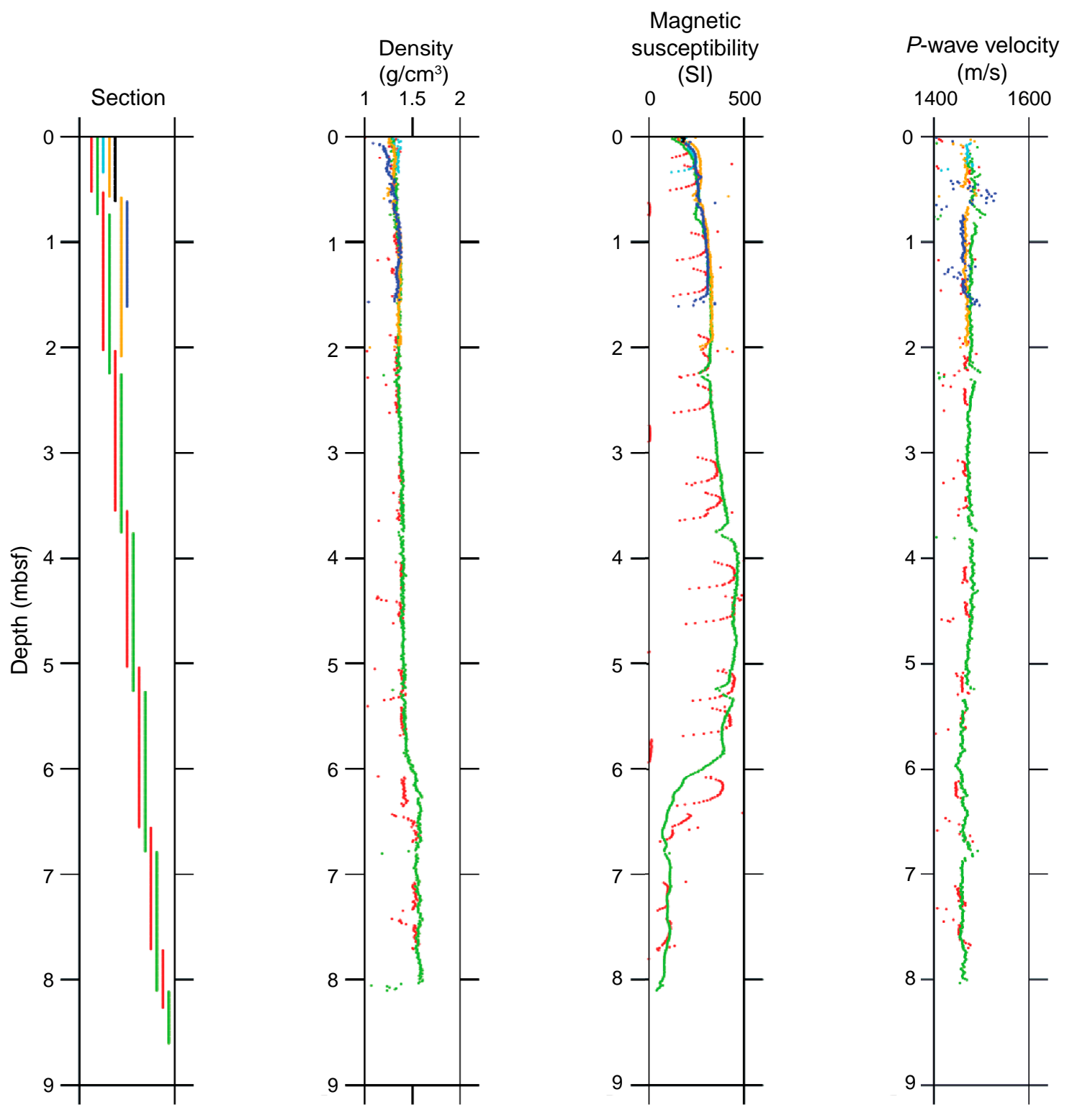


Figure F23. Edited SPG-6 core logs. Density is calculated from gamma counts and core thickness. Red = SPG6P1, green = SPG6-P2, blue = SPG6-T1, cyan = SPG6-T2 .

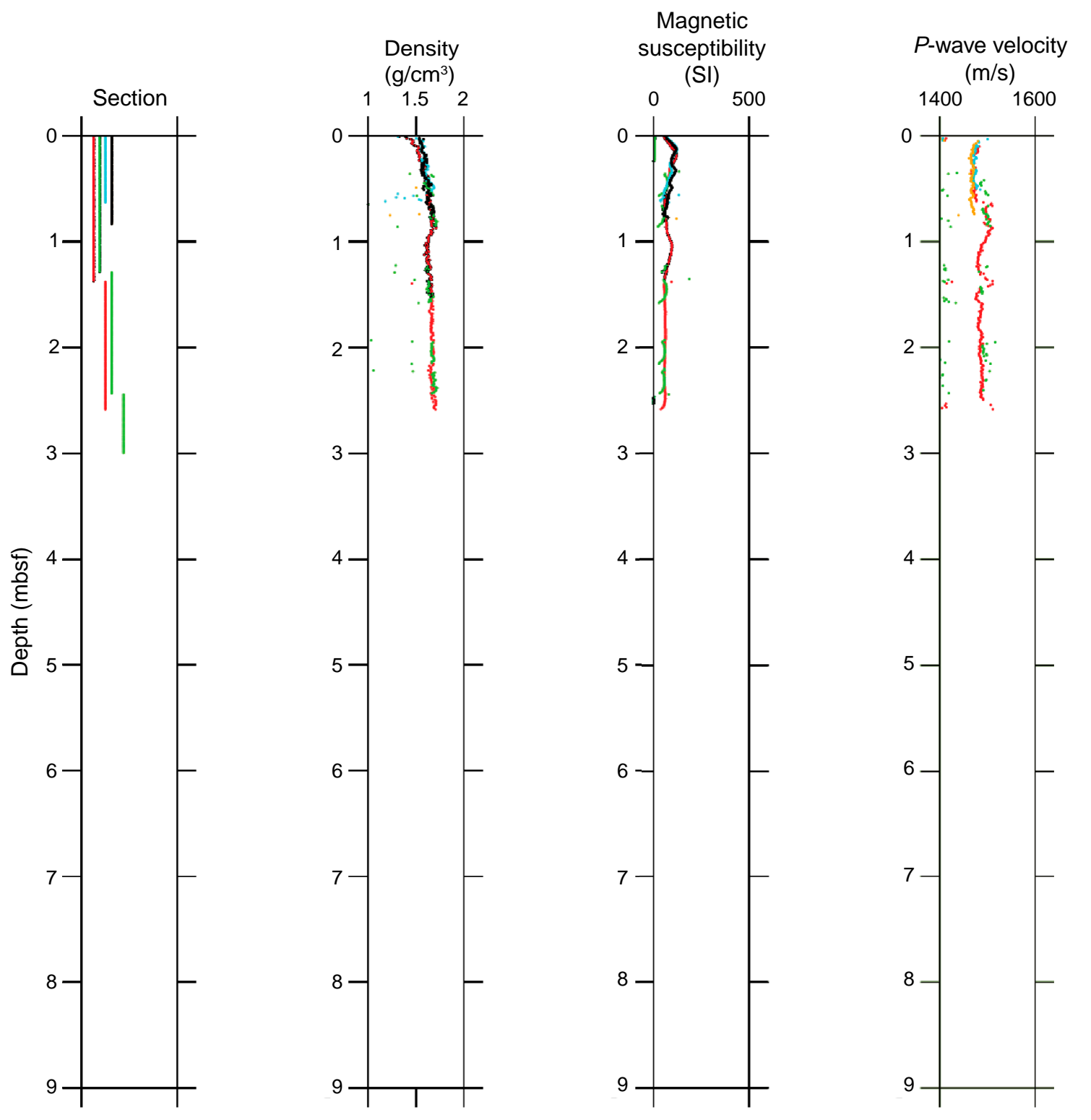


Figure F24. Edited SPG-7 core logs. Density is calculated from gamma counts and core thickness. Red = SPG7P1, green = SPG7-J1, blue = SPG7-G2, cyan = SPG2-M1-1, black = SPG7-M1-7

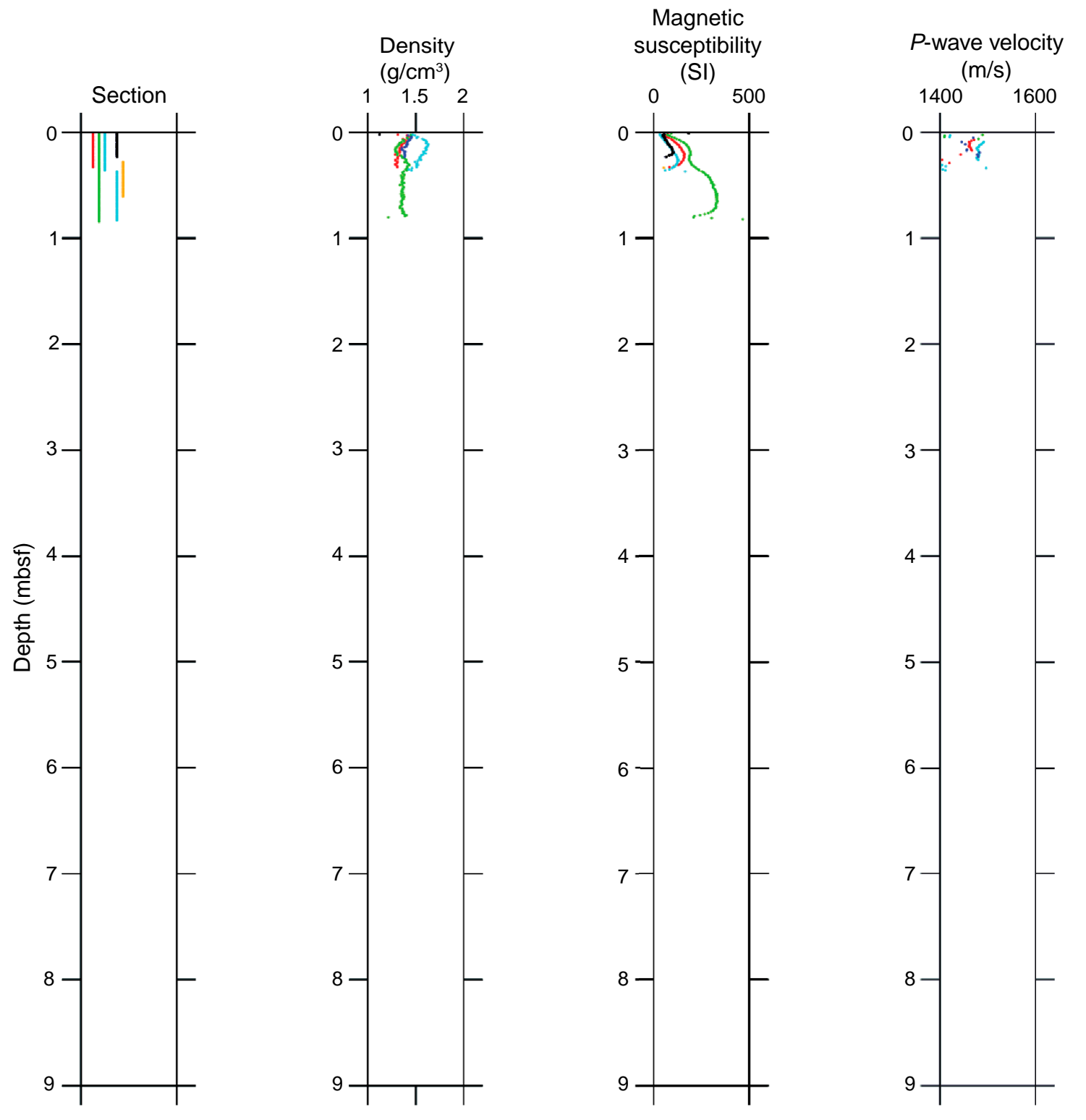


Figure F25. Edited SPG-9 core logs. Density is calculated from gamma counts and core thickness. Red = SPG9P1, green = SPG9-P2, blue = SPG9-M1-7, cyan = SPG9-T1, black = SPG9-T2 .

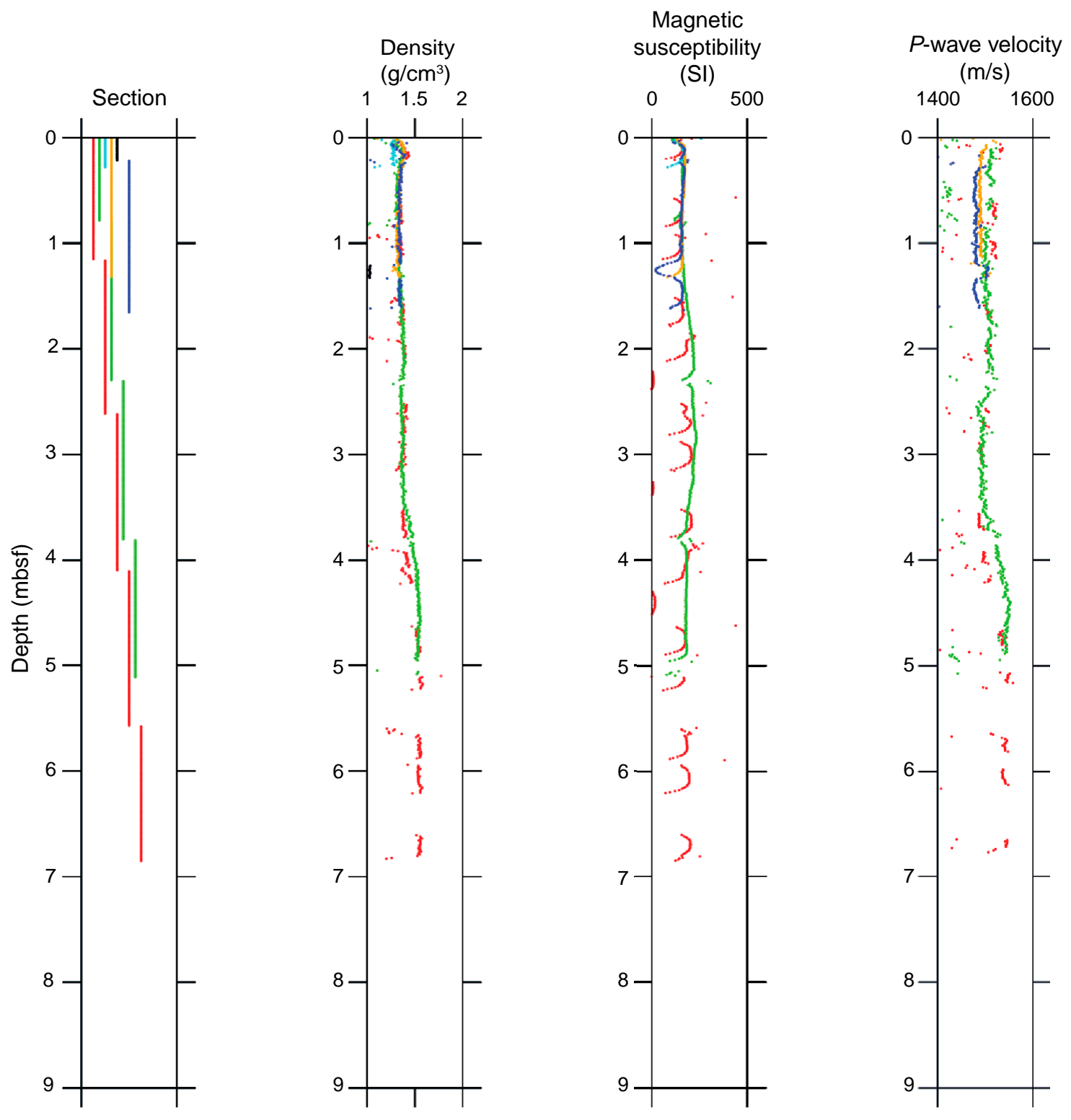


Figure F26. Edited SPG-10 core logs. Panels are as in Fig. PP-1. Red = SPG10-P2, green = SPG10-P3, blue = SPG10M1-7, cyan = SPG10-T1, black = SPG10-T2.

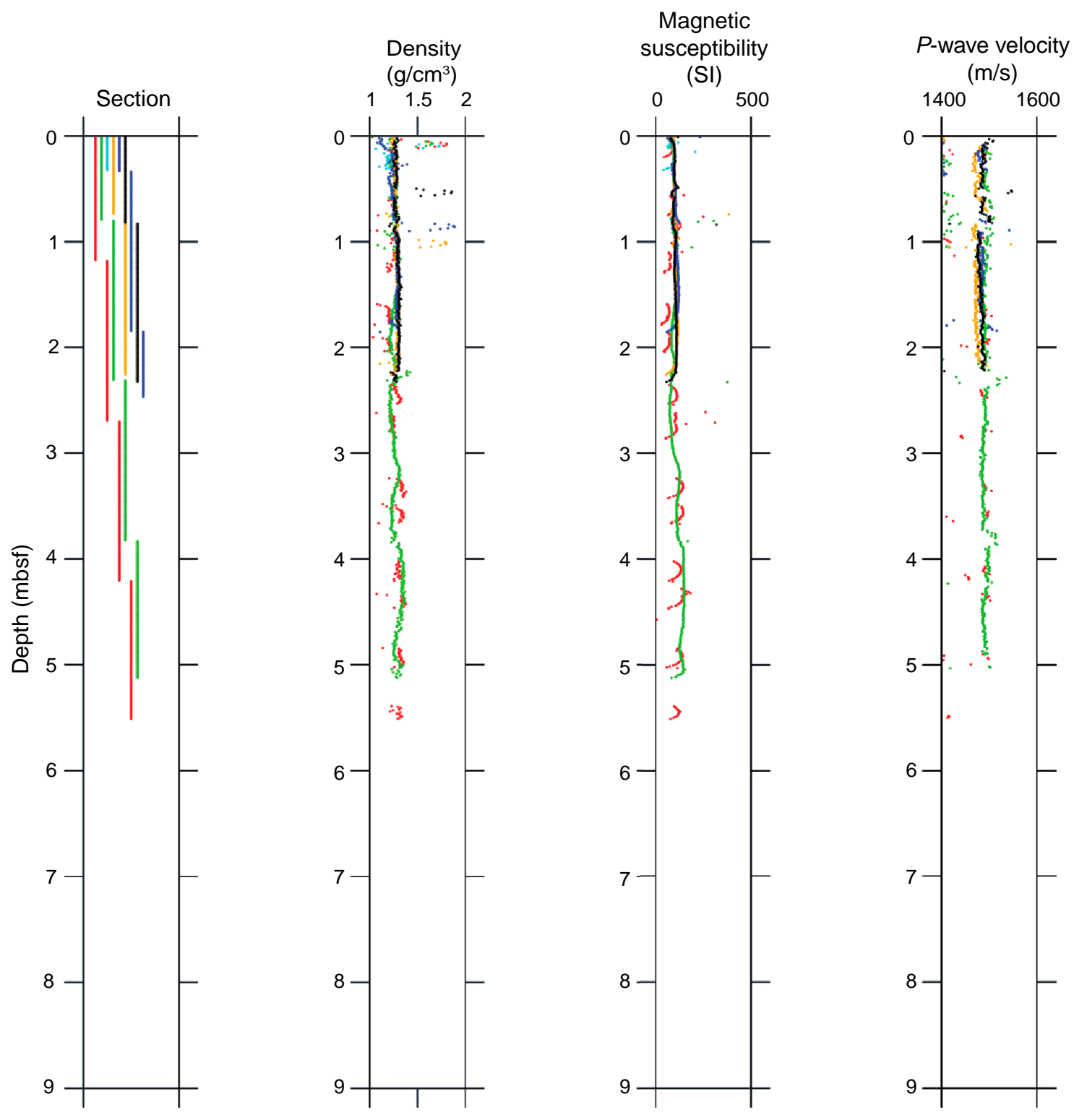


Figure F27. Edited SPG-11 core logs. Density is calculated from gamma counts and core thickness. Red = SPG11TG2, green $=$ SPG11-T1, blue $=$ SPG11-M1 .

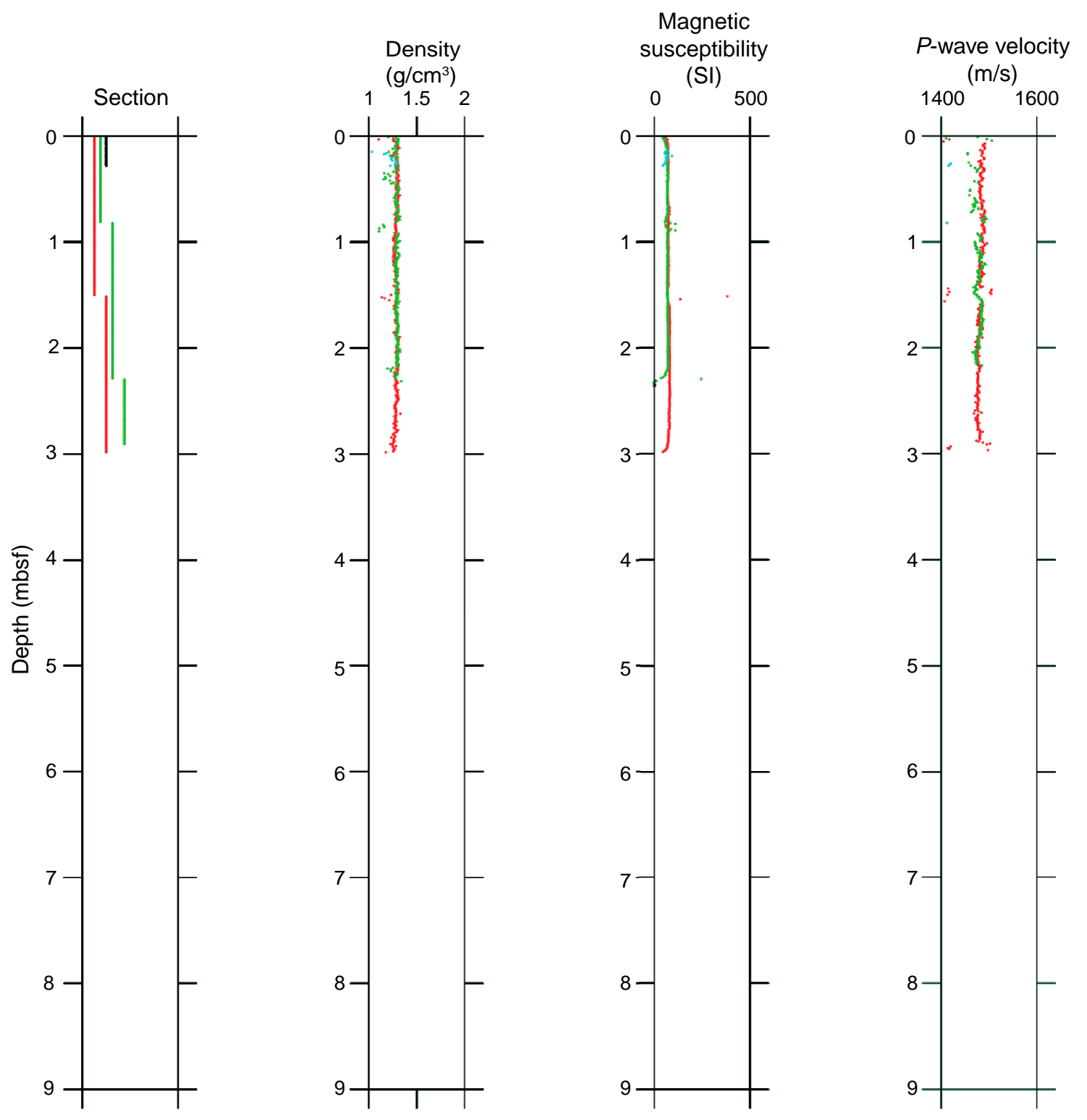


Figure F28. Edited SPG-12 core logs. Density is calculated from gamma counts and core thickness. Red = SPG11TG2, green $=$ SPG11-T3, cyan = SPG11-TG4 .

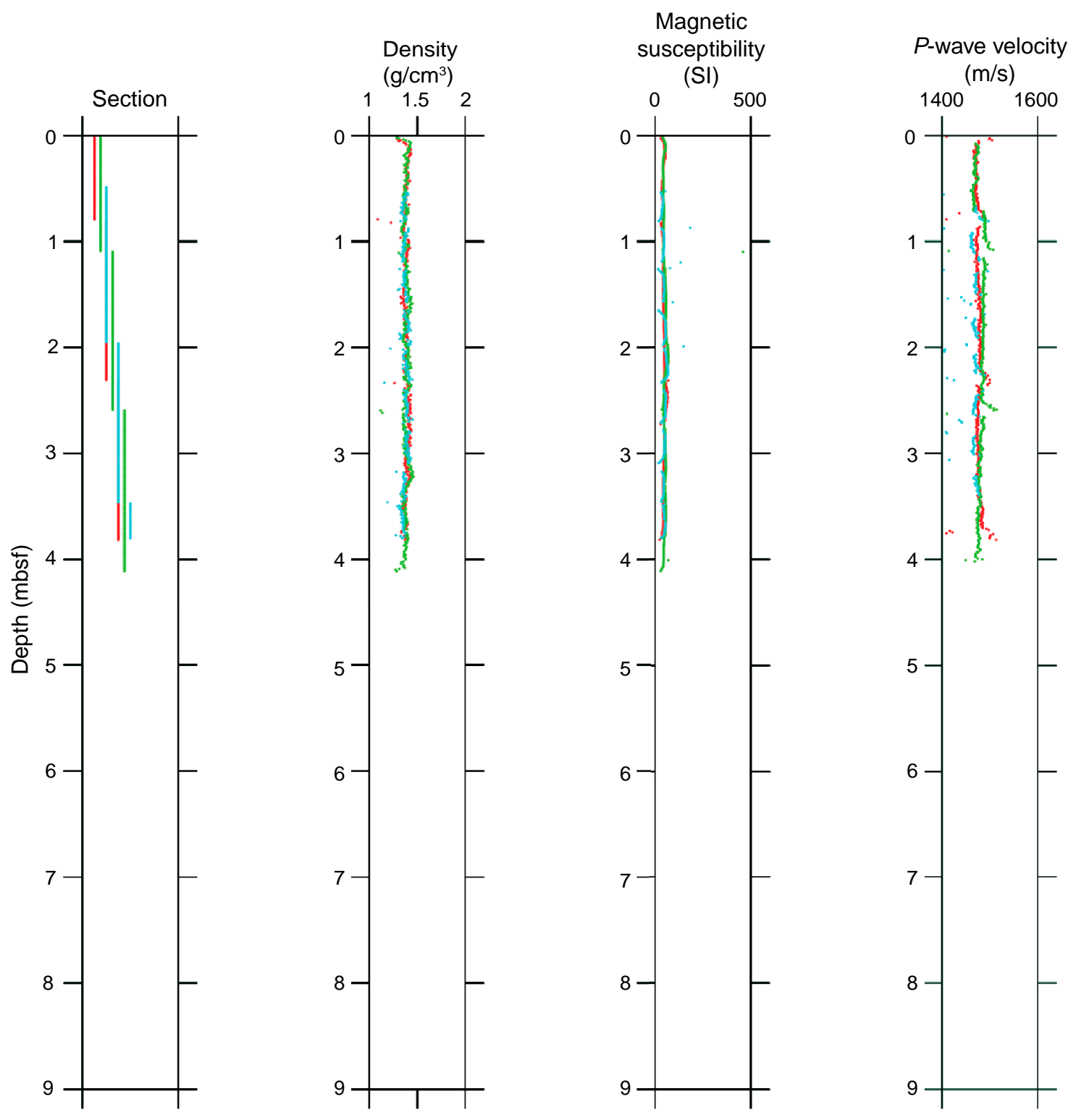


Figure F29. Conductivity data generated on South Pacific Gyre core material. Only data from core material not sampled for interstitial water and microbiology are displayed, as data from these cores are fragmentary and contain abundant edge effects.

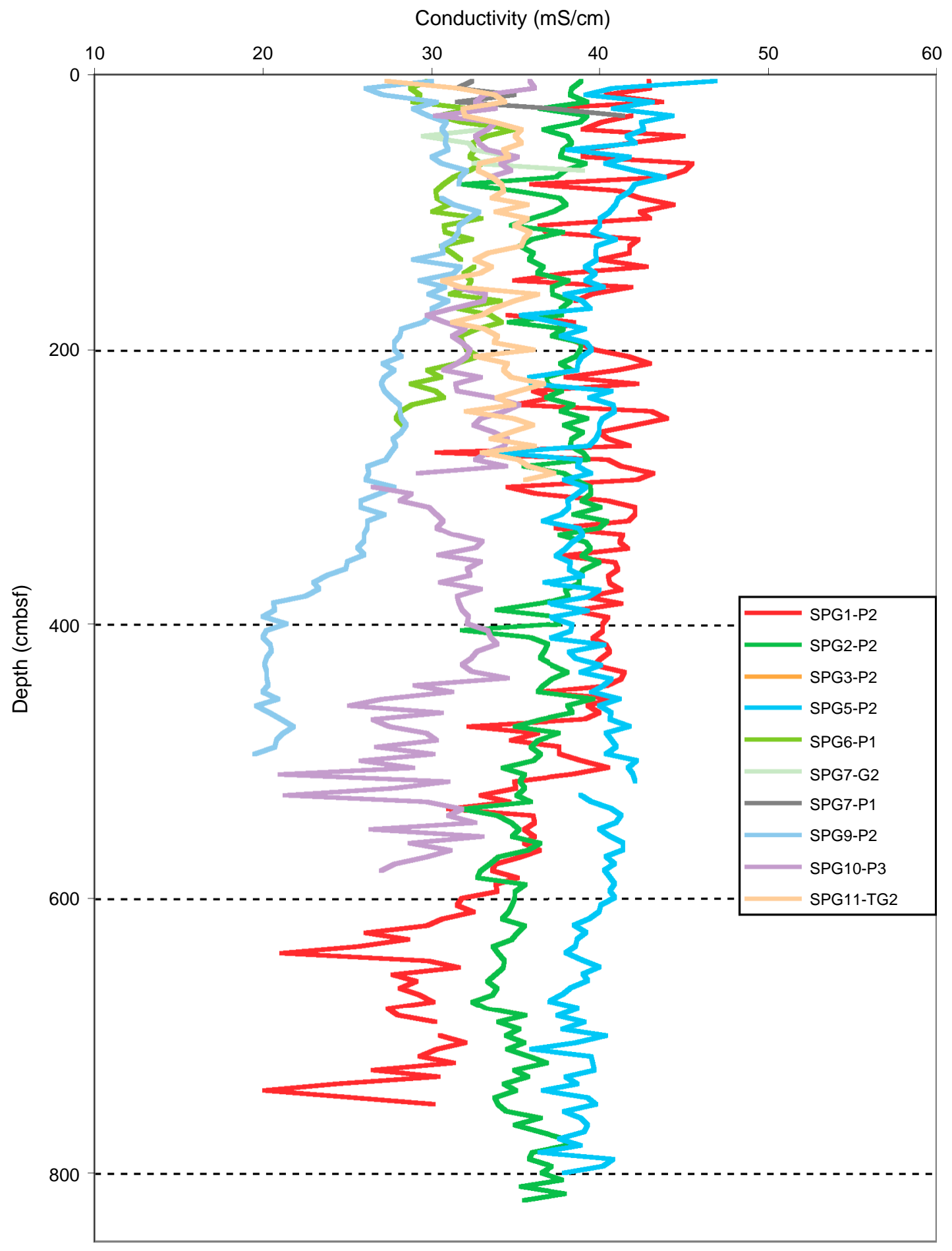


Figure F30. Plots of oxygen profiles measured on cores at all sites.

$$
\mathrm{O}_{2}(\mu \mathrm{M})
$$

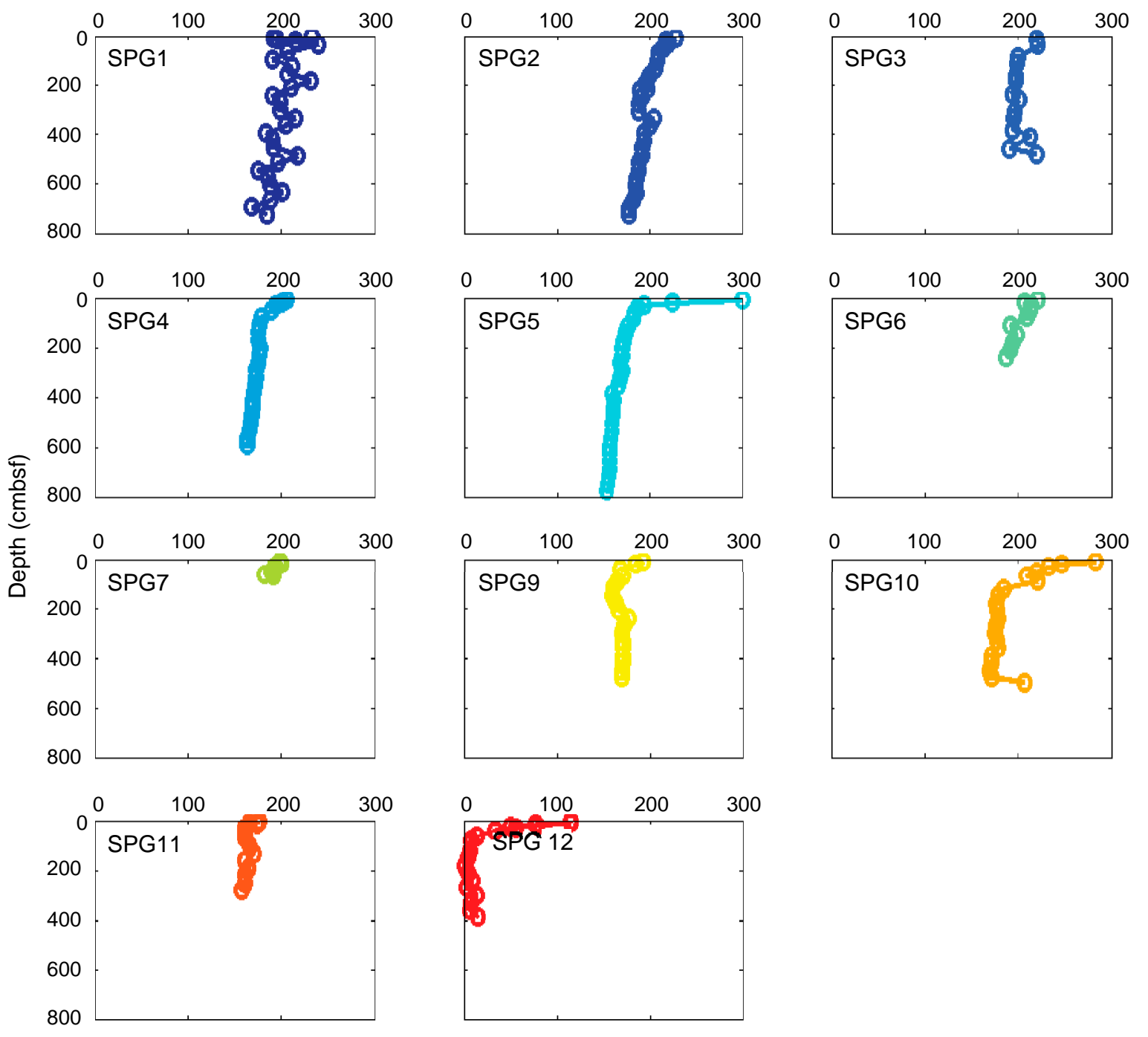


Figure F31. Plots of oxygen microprofiles showing downward oxygen diffusion, measured ex situ on a multicore. The time difference between the profiles is $\sim 2 \mathrm{~h}$.

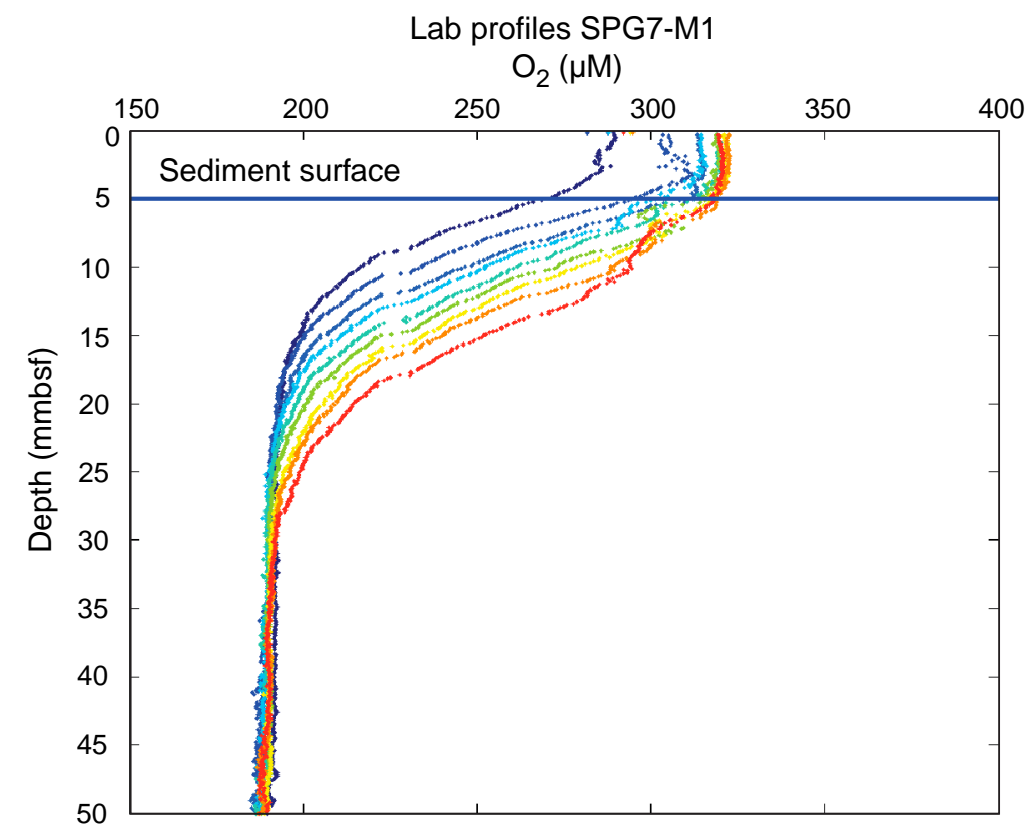


Figure F32. Plot of oxygen microprofile measured with the benthic lander in situ at Site SPG-10.

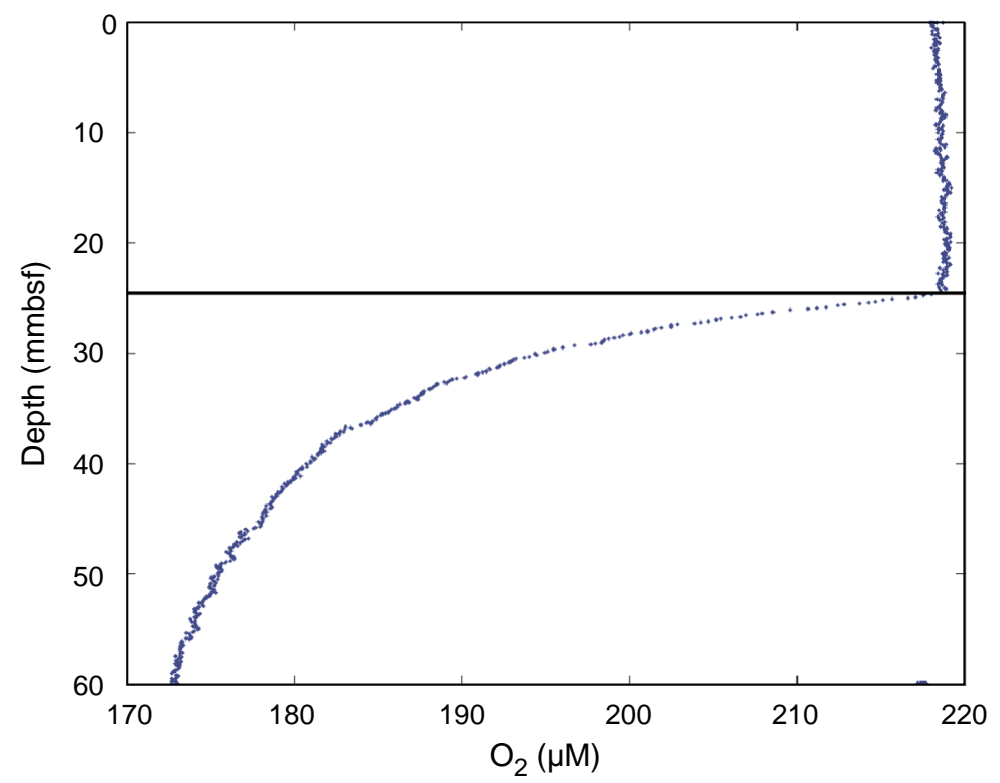


Figure F33. Plots of dissolved (A) alkalinity, (B) nitrate, (C) sulfate, and (D) chloride in interstitial water at South Pacific Gyre sites.

A

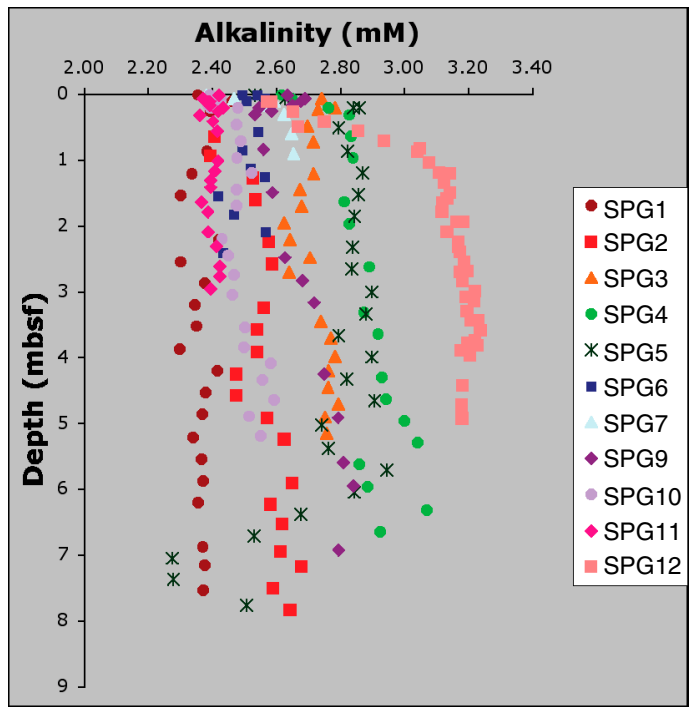

C

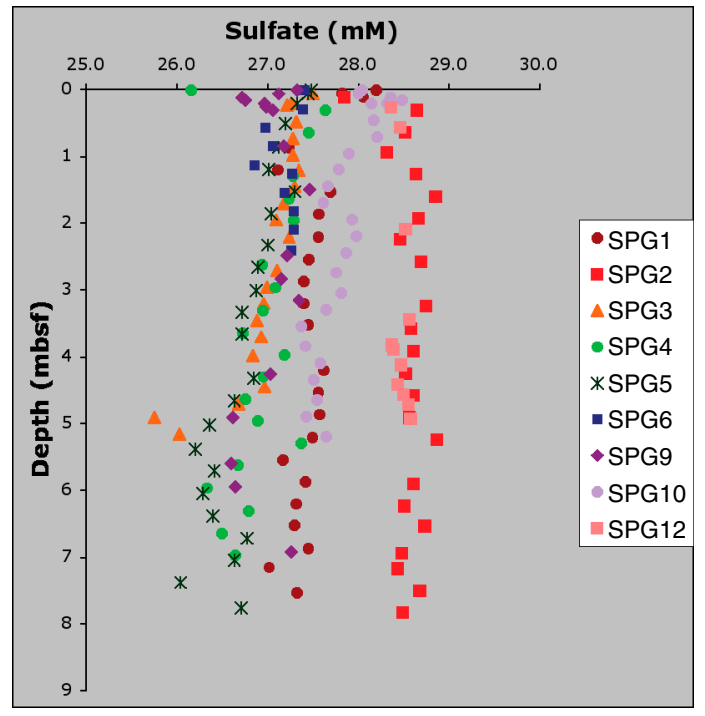

B

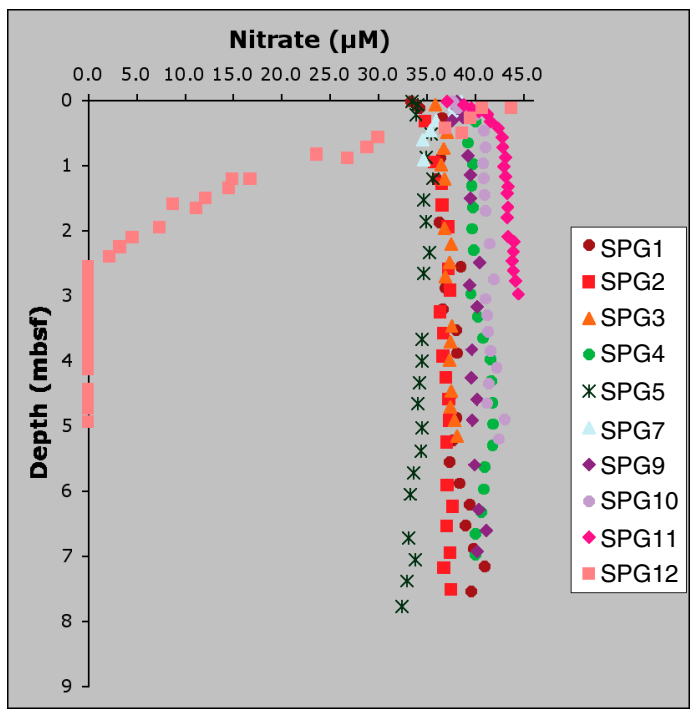

D

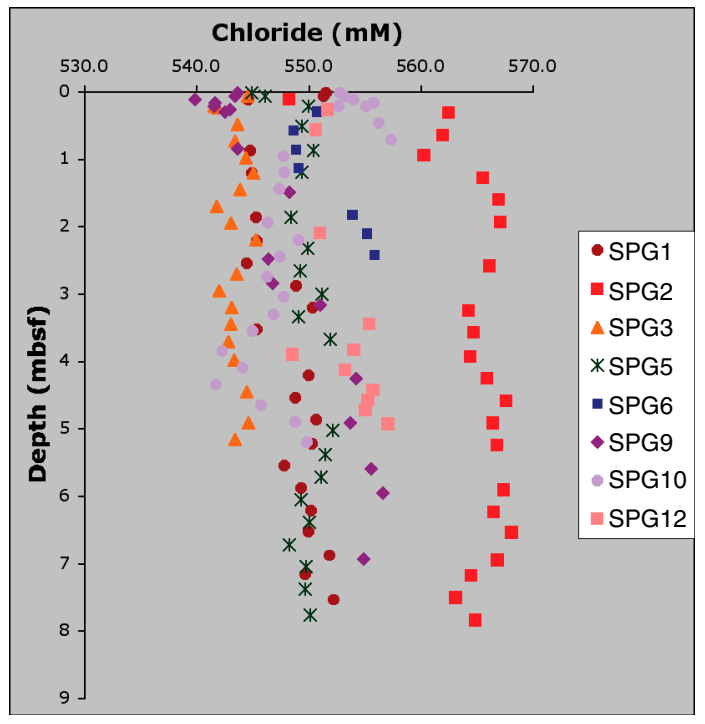


Figure F34. Plots of counted cell concentrations. A. Sites SPG-1-SPG-6. (Continued on next page.)

A

A

SPG1-M1\&P1

$\log _{10}$ cells $/ \mathrm{cm}^{3}$

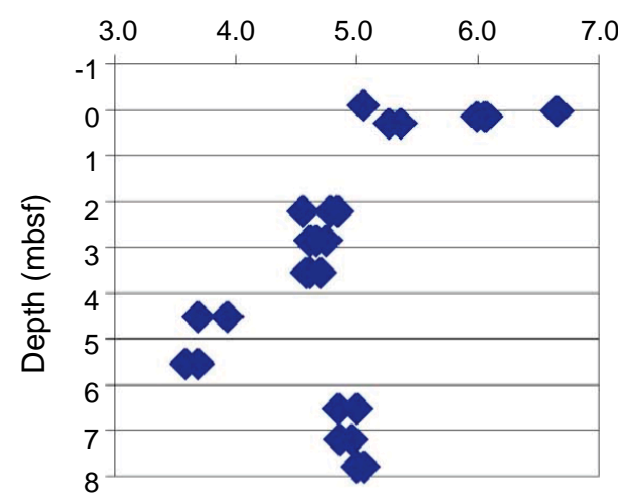

SPG3-M1\&P1

$\log _{10}$ cells $/ \mathrm{cm}^{3}$

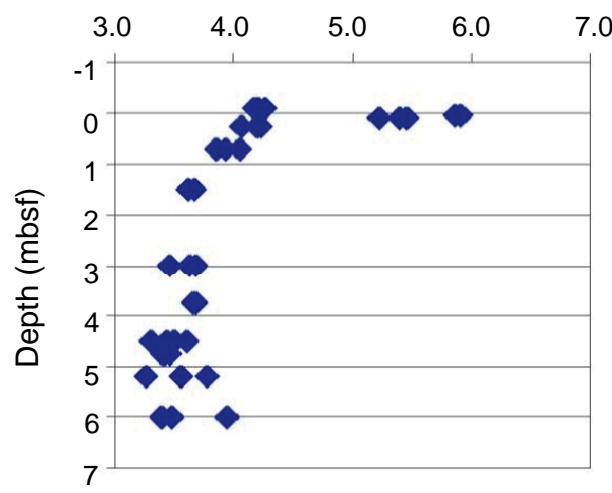

SPG5-M1\&P1

$\log _{10}$ cells $/ \mathrm{cm}^{3}$
SPG2-M1\&P1

$\log _{10}$ cells $/ \mathrm{cm}^{3}$
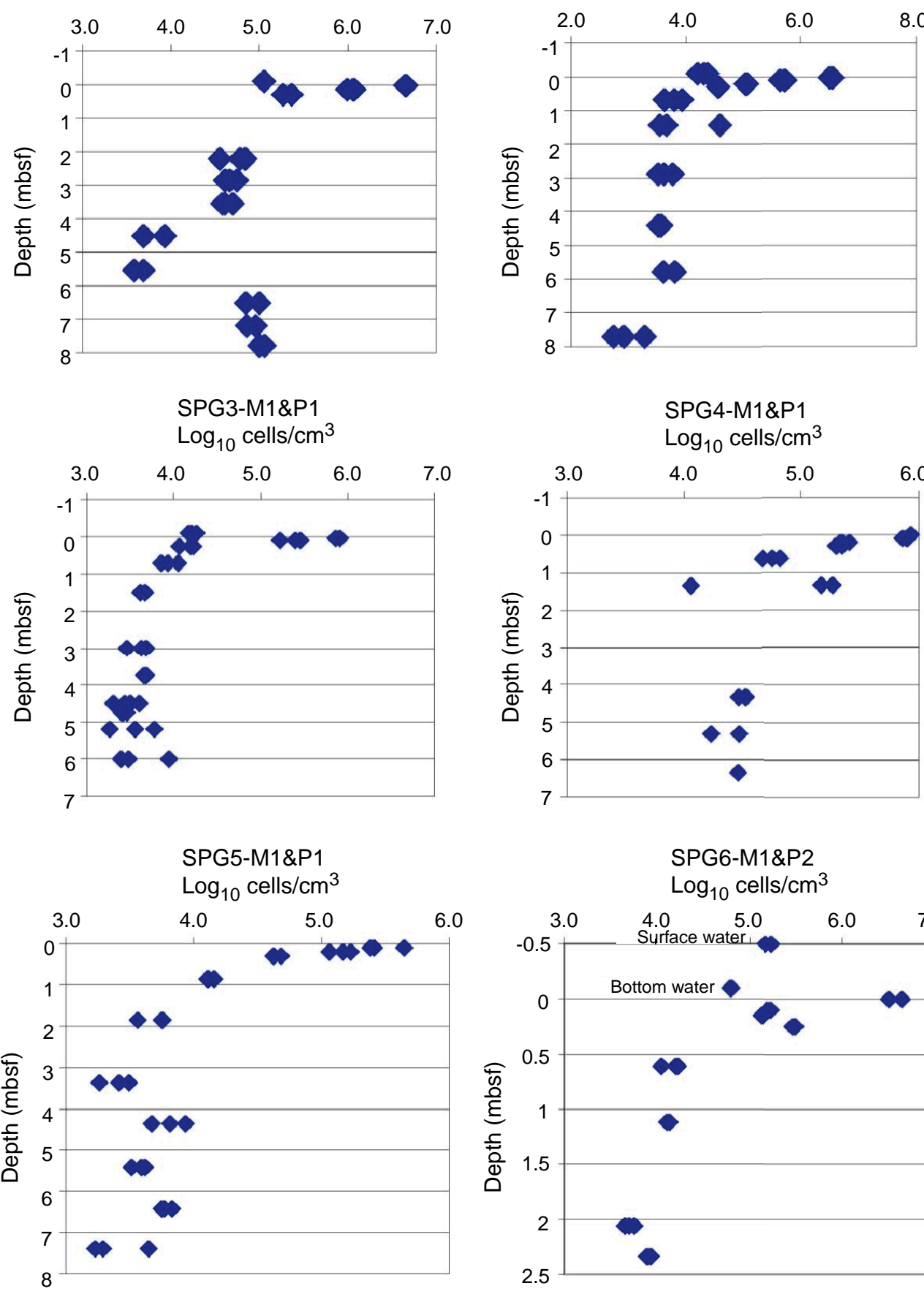

SPG4-M1\&P1

$\log _{10}$ cells $/ \mathrm{cm}^{3}$

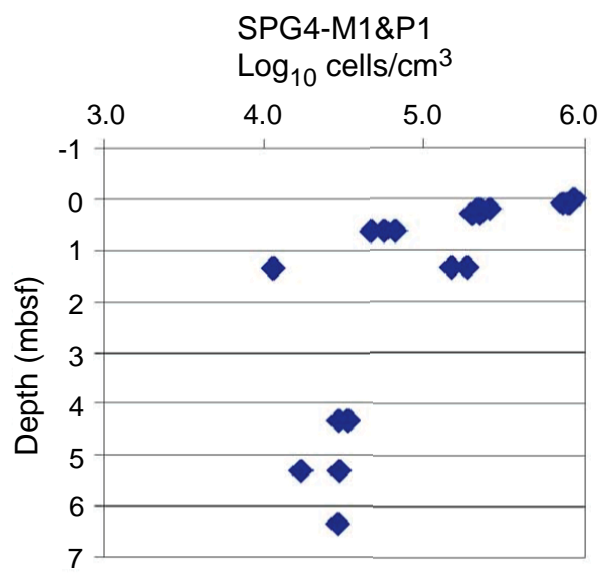

SPG6-M1\&P2

$\log _{10}$ cells $/ \mathrm{cm}^{3}$

8.0

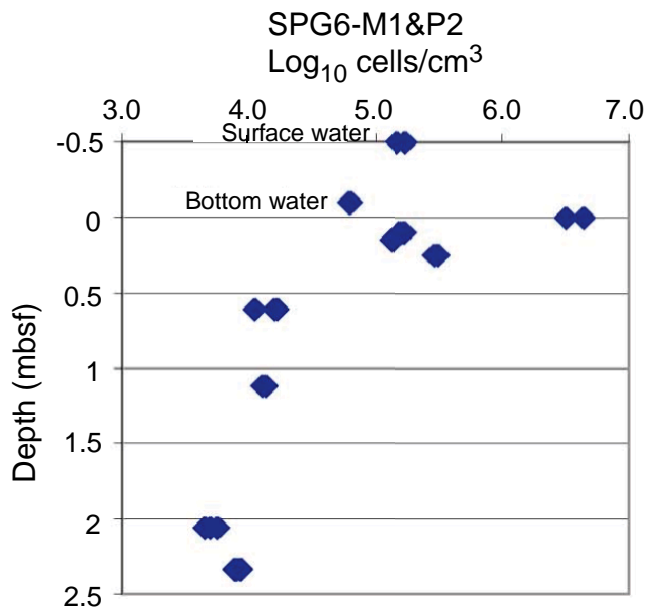


Figure F34 (continued). B. Sites SPG-7-SPG-12.

B
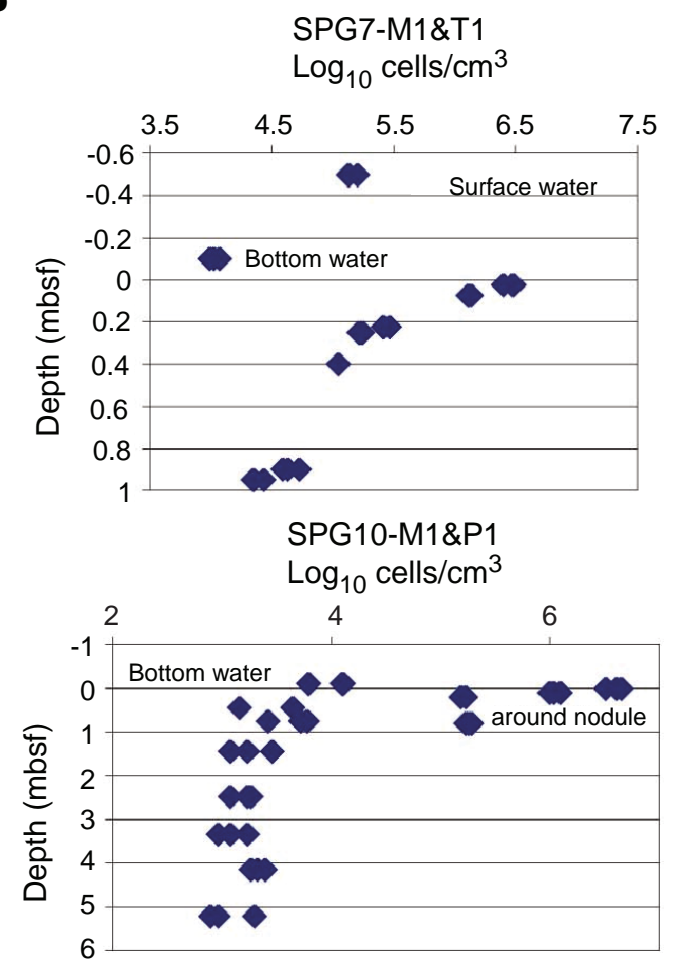

SPG9-M1\&P1

$\log _{10}$ cells $/ \mathrm{cm}^{3}$

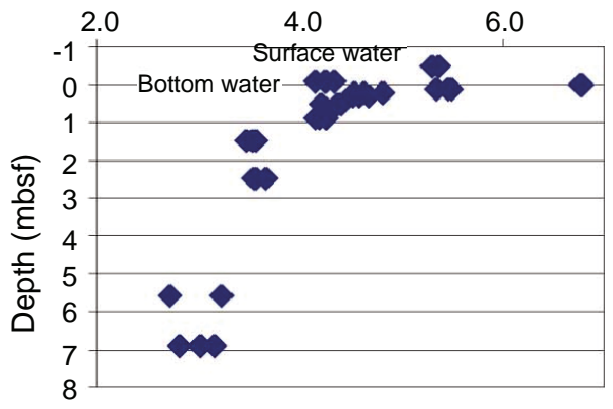

SPG12-TG1,2,4

$\log _{10}$ cells $/ \mathrm{cm}^{3}$

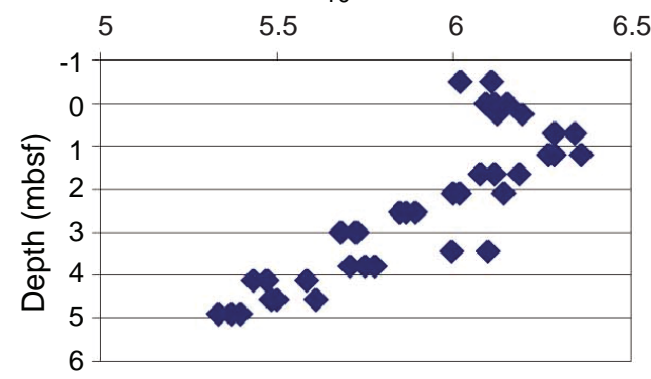


Figure F35. Plot of comparison of South Pacific Gyre cell concentrations to cell concentrations at previously counted Ocean Drilling Program (ODP) sites.

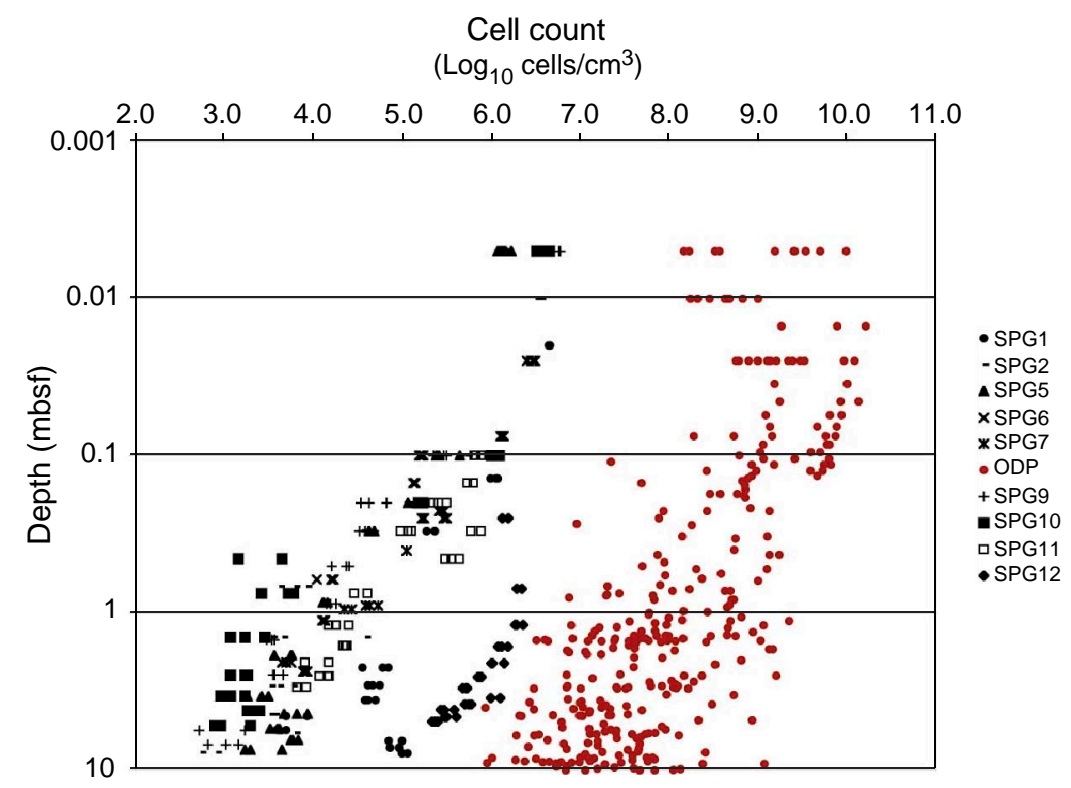




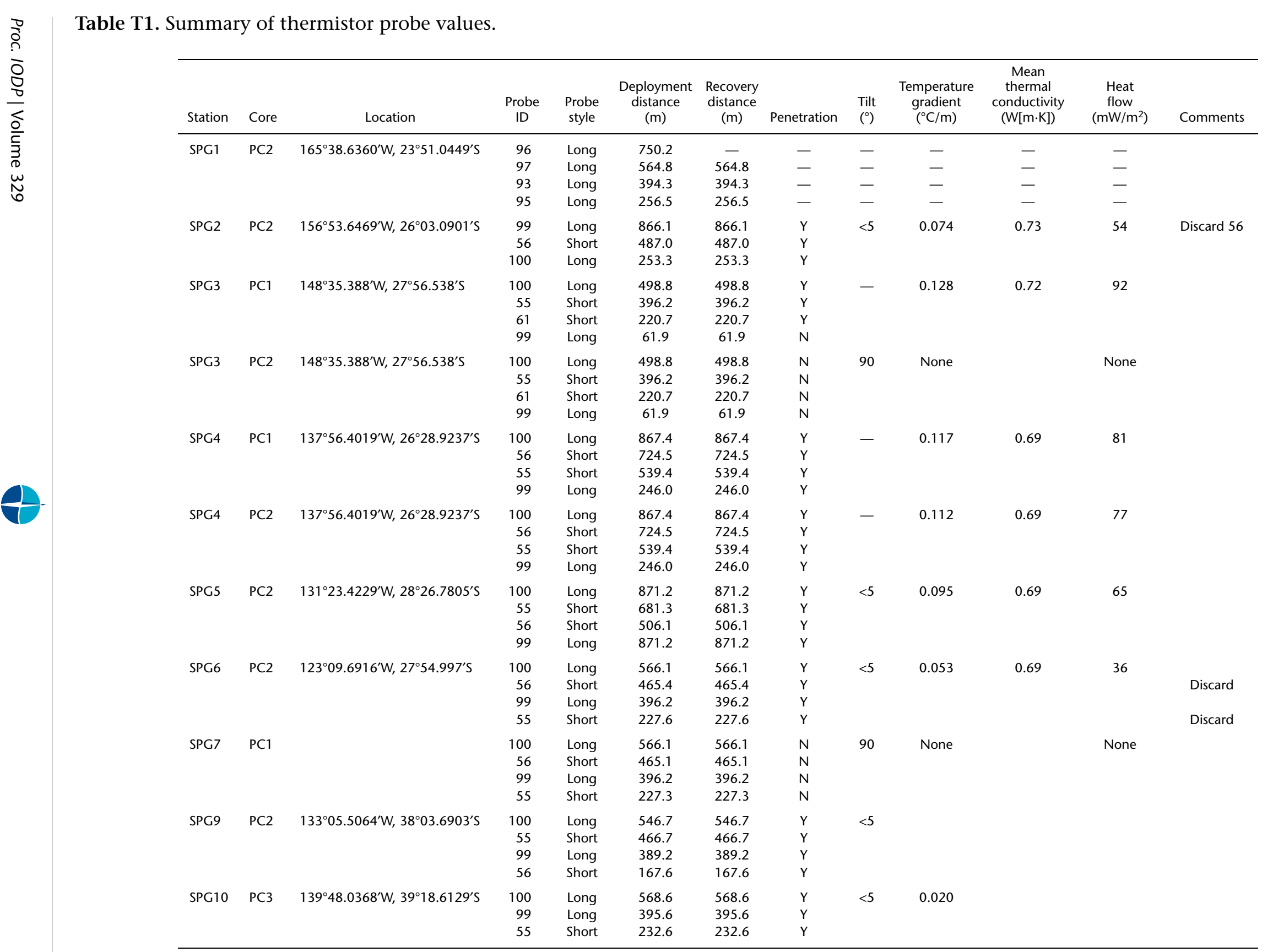


Table T2. Pullout tension data.

\begin{tabular}{cccccll}
\hline Site & $\begin{array}{c}\text { Core length } \\
(\mathrm{ft})\end{array}$ & $\begin{array}{c}\text { Long fins } \\
(N)\end{array}$ & $\begin{array}{c}\text { Short fins } \\
(N)\end{array}$ & $\begin{array}{c}\text { Differential } \\
(\mathrm{lb})\end{array}$ & $\begin{array}{l}\text { Dominant } \\
\text { lithology }\end{array}$ & Comments \\
\hline SPG-1 & 30 & 4 & 0 & 5913 & Red clay & Pullout at $8 \mathrm{~m} / \mathrm{min}$ \\
SPG-2 & 30 & 2 & 1 & 318 & & \\
SPG-3 & 20 & 2 & 2 & 158 & Red clay & \\
SPG-5 & 30 & 2 & 2 & 541 & Red clay & \\
SPG-6 & 20 & 2 & 2 & 4498 & Carbonate & \\
SPG-9 & 20 & 2 & 2 & 1056 & Red clay & \\
SPG-10 & 20 & 2 & 1 & -311 & Red clay & \\
\hline
\end{tabular}

Differential pullout tension is based on the difference between pre-trip tension and maximum pullout tension between cores with and without outrigger probes. No data were collected for Sites SPG-11 and SPG-12. $N=$ number of fins.

Table T3. List of sampling codes from piston and multicore samples.

\begin{tabular}{llllc}
\hline $\begin{array}{c}\text { Sample } \\
\text { code }\end{array}$ & \multicolumn{1}{c}{ Recipient } & \multicolumn{1}{c}{ Sample } & \multicolumn{1}{c}{$\begin{array}{c}\text { Sampling unit } \\
\text { temperature } \\
\left({ }^{\circ} \mathrm{C}\right)\end{array}$} \\
\hline ARC & URI & Archive & $60 \mathrm{~cm}^{3}$ syringe & -80 \\
BIOM & GFZ (Kallmeyer) & Biomarkers & $60 \mathrm{~cm}^{3}$ syringe & -80 \\
CELL & URI (Kallmeyer) & Cell counts & $1 \mathrm{~cm}^{3}$ syringe & Fix \\
CDUST & URI (Smith) & Cosmic dust & Occasional extra whole-round sections & 20 \\
CULAP & MPI (Puschell) & Cultivation & $10 \mathrm{~cm}^{3}$ syringe & 4 \\
EXP & MPI (Ferdelman) & Experiments & $60 \mathrm{~cm}^{3}$ syringe & 4 \\
GAMMA & MPI (Ferdelman) & Gamma ray spectroscopy & $\sim 50 \mathrm{~g}$ taken postsampling and bagged & 20 \\
GRAMP & URI (Forschner) & Cultivation & 3 and 10 cm syringes & 4 \\
H2 & URI (Smith) & Dissolved hydrogen & $3 \mathrm{~cm}^{3}$ in vials & 20 \\
HYD & URI (Soffientino) & Hydrogenase & $3 \mathrm{~cm}^{3}$ syringe & 4 \\
IW & URI (Spivack) & Interstitial water & Whole round & 4 \\
MICAP & MPI (Puschell) & Cell counts & $3 \mathrm{~cm}^{3}$ syringe & Fix \\
MIN & CalTech (Harrison) & Cell-sediment & $30 \mathrm{and}^{3}$ cm syringes & -80 and fix \\
MNN & USC (Horn) & Mn nodule & $\mathrm{NA}$ & $\mathrm{NA}$ \\
RHIZ & URI (Spivack) & Rhizon interstitial water sample & $20 \mathrm{~mL}^{3}$ syringe & 4 \\
SBI & USC (Horn) & Cell-basalt & $30 \mathrm{~cm}^{3}$ syringe & $\mathrm{NA}$ \\
SPC & MPI (Ferdelman) & Solid-phase chemistry & $60 \mathrm{~cm}^{3}$ syringe & -20 \\
TAG & MBL (Smith) & 16S tag sequencing & $60 \mathrm{~cm}^{3}$ syringe & -80 \\
UNC-A & UNC (Durbin) & 16S DNA and RNA & $60 \mathrm{~cm}^{3}$ syringe & -80 \\
UNC-M & UNC (Lever) & Functional genes & $60 \mathrm{~cm}^{3}$ syringe & -80 \\
\hline
\end{tabular}

URI = University of Rhode Island, GFZ = German Research Centre for Geosciences, MPI = Max-Planck Institute for Marine Microbiology, CalTech = California Institute of Technology, USC = University of Southern California, UNC = University of North Carolina at Chapel Hill. NA = not applicable. 
Table T4. General scheme for subsampling multicores.

\begin{tabular}{clll}
\hline MUC & Code & \multicolumn{1}{c}{ Analysis/Use } & \multicolumn{1}{c}{ Notes } \\
\hline 1 & CULT & Cultivation & Section and distribute for cultivation studies. \\
2 & EXP & Experimental N, S, $\mathrm{H}$ & Section and slurry for ${ }^{15} \mathrm{~N}^{35} \mathrm{~S}_{\text {, and }}{ }^{3 \mathrm{H}}$ experiments. \\
3 & DCC & Direct cell counts: AODC/FISH & Section and distribute for cell counting, CARD-FISH others, $\mathrm{H}_{2}$ sample. \\
4 & $\mathrm{MOL}$ & Molecular work & Section and freeze at $-80^{\circ} \mathrm{C}$ for molecular work. \\
5 & IW & Interstitial water chemistry & Section for three or more interstitial water depths. \\
6 & SPC/O2 & Solid-phase chemistry and $\mathrm{O}_{2}$ distributions & Run electrode profiler for surface $\mathrm{O}_{2}$ concentration and subcore surface for fine-scale \\
& & geochemistry. & \\
7 & LPP & Lithology, physical properties & Extrude into split sleeve. Deliver to multisensor track and then to Geology. \\
8 & ARC & Archive & Section surface and three depths; freeze at $-80^{\circ} \mathrm{C}$. \\
& OW & Overlying water & Deep water overlying the surface sediment from individual cores or pooled from several cores. \\
\hline
\end{tabular}

MUC = multicore sample. AODC $=$ acridine orange direct count, CARD-FISH = catalyzed reporter deposition-fluorescence in situ hybridization.

Table T5. Subsampling scheme and treatments for KNOX-02RR postcruise interstitial water studies.

\begin{tabular}{|c|c|c|}
\hline Analysis & Sample size $(\mathrm{mL})$ & Treatment \\
\hline Cations & 0.75 & Stored at $4^{\circ} \mathrm{C}$ \\
\hline $\mathrm{NH}_{4}$ & 4.5 & $45 \mu \mathrm{L}$ Optima $\mathrm{HCl}$ \\
\hline$\delta^{15} \mathrm{~N}$ of dissolved $\mathrm{NO}_{3}$ and/or $\mathrm{NH}_{4}$ & $4.5(\times 2)$ & Frozen at $-10^{\circ} \mathrm{C}$ \\
\hline $\begin{array}{l}\text { DOC, DON, carbohydrates, dissolved amino acids, fatty acids, } \delta^{13} \mathrm{C} \\
\text { of DOC }\end{array}$ & $3.5(\times 2)$ & Frozen at $-10^{\circ} \mathrm{C}$ \\
\hline$\delta^{13} \mathrm{C}$ of DIC & 3.5 & $10 \mu \mathrm{L} \mathrm{HgCl} 2$ \\
\hline DIC & 2 & $10 \mu \mathrm{L} \mathrm{HgCl}$, flushed with $\mathrm{N}_{2}$ for $2 \mathrm{~min}$, inverted and frozen at $-10^{\circ} \mathrm{C}$ \\
\hline $\mathrm{He}$ & 1 (in copper tubing) & Room temperature \\
\hline Dissolved $\mathrm{Fe}, \mathrm{Mn}$, and $\mathrm{PO}_{4}$ & 4.5 & $45 \mu \mathrm{L}$ Optima $\mathrm{HNO}_{3}$ \\
\hline Squeezed sediment & NA & Frozen at $-10^{\circ} \mathrm{C}$ \\
\hline
\end{tabular}

$\mathrm{NA}=$ not applicable. $\mathrm{DOC}=$ dissolved organic carbon, $\mathrm{DON}=$ dissolved organic nitrogen, $\mathrm{DIC}=$ dissolved inorganic carbon. 
Table T6. Survey, lander, and coring operations, Sites SPG-1-SPG-12. (Continued on next five pages.)

\begin{tabular}{|c|c|c|c|c|c|c|}
\hline $\begin{array}{l}\text { Site SPG-1 } \\
\text { Latitude: } 23^{\circ} 51.05^{\prime} \mathrm{S} \\
\text { Longitude: } 165^{\circ} 38.635^{\prime} \mathrm{W} \\
\text { Water depth (mbsl): } 5699\end{array}$ & & & & & & \\
\hline $\begin{array}{l}\text { Seismic survey } \\
\text { Date: } 20-21 \text { Dec } 2006 \\
\text { Time launched (h): } 1801 \\
\text { Time recovered (h): } 0152 \\
\text { Number of birds: } 4\end{array}$ & & & & & & \\
\hline Coring operations & & & & & & \\
\hline Coring tool: & Gravity & Trigger & Piston & Multicore & Trigger & Piston \\
\hline Deployment number: & 1 & 1 & 1 & 1 & 2 & 2 \\
\hline Date (2006): & $21 \mathrm{Dec}$ & $21 \mathrm{Dec}$ & $21 \mathrm{Dec}$ & $21 \mathrm{Dec}$ & $21-22 \mathrm{Dec}$ & $21-22 \mathrm{Dec}$ \\
\hline Time launched (h): & 0230 & 0710 & 0710 & 1510 & 2150 & 2150 \\
\hline Time on bottom $(\mathrm{h})$ : & 0350 & 0941 & 0941 & 1712 & 0019 & 0019 \\
\hline Time recovered $(\mathrm{h})$ : & 0520 & 1236 & 1236 & 1938 & 0323 & 0323 \\
\hline Tension (lb) & & & & & & \\
\hline Surface: & 380 & 4,500 & 4,500 & - & 4,500 & 4,500 \\
\hline Prior to trip: & 1,250 & 12,500 & 12,500 & 9,000 & 12,500 & 12,500 \\
\hline On bottom: & - & 8,500 & 8,500 & 9,000 & 8,500 & 8,500 \\
\hline Pullout maximum: & 2,429 & 17,687 & 17,687 & 10,200 & 23,600 & 23,600 \\
\hline Ascending: & 1,800 & 13,500 & 13,500 & 9,700 & 13,500 & 13,500 \\
\hline Corer length (ft): & 10 & 10 & 30 & NA & 10 & 30 \\
\hline Total sediment recovered $(\mathrm{cm}:)$ & 175 & 211 & 779 & $29.5(4 / 8)$ & 281 & 775 \\
\hline Thermistors: & NA & NA & NA & NA & NA & 4 \\
\hline Weight on trigger/gravity core: & NA & $7 \mathrm{~Pb}$ & No pigs & NA & NA & No pigs \\
\hline Comments: & $\begin{array}{r}\text { Multicor } \\
\text { recove }\end{array}$ & $\begin{array}{l}\text { iment rec } \\
\text { of eight, i }\end{array}$ & $\begin{array}{l}\text { ed indicat } \\
\text { ated in san }\end{array}$ & $\begin{array}{l}\text { the average } \\
\text { cell. }\end{array}$ & f cores recc & ered. Cores \\
\hline
\end{tabular}

Site SPG-2

Latitude: $26^{\circ} 03.088^{\prime} \mathrm{S}$

Longitude: $156^{\circ} 53.646^{\prime} \mathrm{W}$

Water depth (mbsl): 5126

Seismic survey

Date: 23 Dec 2006

Time launched (h): 2357

Time recovered (h): 0809

Number of birds: 4

Lander operations

Latitude: $26^{\circ} 03.115^{\prime} \mathrm{S}$

Longitude: $156^{\circ} 53.841^{\prime} \mathrm{W}$

Date: 24 Dec 2006

Time launched (h): 1322

Time recovered (h): 1400

Coring operations

Coring tool:
Deployment number:
Date $(2006):$
Time launched $(h):$
Time on bottom $(h):$
Time recovered $(h):$

Multicore
1
$24 \mathrm{Dec}$
0822
1021
1244

Trigger
1
$24 \mathrm{Dec}$
1453
1706
1950

Piston
1
$24 \mathrm{Dec}$
1453
1706
1950

$\begin{array}{cc}\text { Trigger } & \text { Piston } \\ 2 & 2 \\ 24 \mathrm{Dec} & 24 \mathrm{Dec} \\ 2217 & 2217 \\ 0025 & 0025 \\ 0250 & 0250\end{array}$

Tension (lb)

Surface:

$\begin{array}{rr}1,450 & 4,625 \\ 8,700 & 11,500 \\ 7,500 & 8,500 \\ 10,900 & 16,742 \\ 9,500 & 12,700 \\ \text { NA } & 10\end{array}$

$$
4,625
$$

11,500

On bottom:

Pullout maximum:

Ascending:

Corer length ( $\mathrm{ft}$ ):

Total sediment recovered $(\mathrm{cm})$ :

Thermistors:

Weight on trigger/gravity core:

Comments:

$\begin{array}{ccccc}\text { NA } & 10 & 30 & 10 & 30 \\ 17.25(4 / 8) & 260 & 814.5 & 252 & 819.5 \\ \text { NA } & \text { NA } & \text { NA } & \text { NA } & 3 \\ \text { NA } & \text { NA } & \text { No pigs } & \text { NA } & \end{array}$

Multicore 1: Cores 6, 7, 8 contain no sample due to leakage on recovery. Multicore sediment recovered indicates the average of cores recovered. Cores recovered, of eight, indicated in same cell. 
Table T6 (continued). (Continued on next page.)

Site SPG-3

Latitude: $27^{\circ} 56.540^{\prime} \mathrm{S}$

Longitude: $148^{\circ} 35.386^{\prime} \mathrm{W}$

Water depth (mbsl): 4856

Seismic survey

Date: 26 Dec 2006

Time launched (h): 1705

Time recovered (h): 0125

Number of birds: 4

Lander operations

Latitude: $27^{\circ} 56.663^{\prime} \mathrm{S}$

Longitude: $148^{\circ} 35.507^{\prime} \mathrm{W}$

Date: 27-28 Dec 2006

Time launched (h): 1038

Time recovered (h): 0015

Coring operations

$$
\text { Coring tool: }
$$

Deployment number: Date (2006):

Time launched (h):

Time on bottom (h)

Time recovered $(h)$ :

Tension (lb)

Surface:
Prior to trip:
On bottom:
Pullout maximum:
Ascending:
Corer length $(\mathrm{ft}):$
ent recovered $(\mathrm{cm}):$
Thermistors:
rigger/gravity core:

Comments:

Site SPG-4

Latitude: $26^{\circ} 28.924^{\prime} \mathrm{S}$

Longitude: $137^{\circ} 56.403^{\prime} \mathrm{W}$

Water depth (mbsl): 4285

Seismic survey

Date: 29 Dec 2006

Time launched (h): 2348

Time recovered (h): 0635

Number of birds: 4

Coring operations

$$
\begin{array}{r}
\text { Coring tool: } \\
\text { Deployment number: } \\
\text { Date }(2006) \text { : } \\
\text { Time launched }(h): \\
\text { Time on bottom }(h): \\
\text { Time recovered }(h):
\end{array}
$$

Tension (lb)

$$
\begin{array}{r}
\text { Surface: } \\
\text { Prior to trip: } \\
\text { On bottom: } \\
\text { Pullout maximum: } \\
\text { Ascending: } \\
\text { Corer length }(\mathrm{ft}): \\
\text { Thermistors: } \\
\text { rigger/gravity core: } \\
\text { Comments: }
\end{array}
$$

Total sediment recovered $(\mathrm{cm})$ :

Weight on trigger/gravity core:

$\begin{array}{cccccc}\text { Gravity } & \text { Multicore } & \text { Trigger } & \text { Piston } & \text { Trigger } & \text { Piston } \\ 1 & 1 & 1 & 1 & 2 & 2 \\ 27 \mathrm{Dec} & 27 \mathrm{Dec} & 27 \mathrm{Dec} & 27 \mathrm{Dec} & 27 \mathrm{Dec} & 27 \mathrm{Dec} \\ 0248 & 0549 & 1135 & 1135 & 1831 & 1831 \\ 0351 & 0744 & 1342 & 1342 & 2034 & 2034 \\ 0454 & 0949 & 1617 & 1617 & 2304 & 2304 \\ & & & & & \\ 400 & 2,000 & 4,600 & 4,600 & 4,700 & 4,700 \\ 1,600 & 7,500 & 11,300 & 11,300 & 11,000 & 11,000 \\ 1,200 & 7,000 & 7,800 & 7,800 & 7,500 & 7,500 \\ 2,218 & 9,800 & 14,742 & 14,742 & 14,600 & 14,600 \\ - & 8,600 & 12,500 & 12,500 & 11,000 & 11,000 \\ 10 & \text { NA } & 10 & 20 & 10 & 20 \\ 186 & 38.8(6 / 8) & 216.5 & 549 & 0 & 430 \\ \text { NA } & \text { NA } & \text { NA } & 4 & \text { NA } & 4\end{array}$

Replaced 1 small $\mathrm{Pb}$ weight with 3 larger $\mathrm{TC} / \mathrm{GC} \mathrm{Pb}$ weights $\sim 500 \mathrm{lb}$

Piston 1: Core cutter deformed. Trigger 2: Core cutter lost (rivets sheared off), core probably fell out. Piston 2: Core cutter deformed, piston core most likely plugged and drew in water. Multicore sediment recovered indicates the average of cores recovered. Cores recovered, of eight, indicated in same cell.

$\begin{array}{cccccc}\text { Multicore } & \text { Gravity } & \text { Trigger } & \text { Piston } & \text { Trigger } & \text { Piston } \\ 1 & 1 & 1 & 1 & 2 & 2 \\ 30 \mathrm{Dec} & 30 \mathrm{Dec} & 30 \mathrm{Dec} & 30 \mathrm{Dec} & 30 \mathrm{Dec} & 30 \mathrm{Dec} \\ 0730 & 1138 & 1430 & 1430 & 2137 & 2137 \\ 0913 & 1240 & 1621 & 1621 & 2331 & 2331 \\ 1116 & 1344 & 1843 & 1843 & 0130 & 0130 \\ & & & & & \\ 2,000 & 451 & 4,500 & 4,500 & 4,910 & 4,910 \\ 7,000 & - & 10,500 & 10,500 & 10,500 & 10,500 \\ 6,060 & 1,100 & 7,000 & 7,000 & 7,037 & 7,037 \\ 8,791 & 2,301 & 18,838 & 18,838 & 16,525 & 16,525 \\ 8,000 & 1,700 & 11,500 & 11,500 & 5,300 & 5,300 \\ & 10 & 10 & 30 & 10 & 30 \\ 31(8 / 8) & 191 & 111 & 724 & 256.5 & 630 \\ \text { NA } & \text { NA } & \text { NA } & 4 & \text { NA } & 4 \\ \text { NA } & \text { NA } & \text { NA } & \text { NA } & 7 \text { Pb rings } & \text { NA }\end{array}$

Multi--core sediment recovered indicates the average of cores recovered. Cores recovered, of eight, indicated in same cell. 
Table T6 (continued). (Continued on next page.)

\section{Site SPG-5}

Latitude: $28^{\circ} 26.780^{\prime} \mathrm{S}$

Longitude: $131^{\circ} 23.424^{\prime} \mathrm{W}$

Water depth (mbsl): 4222

Seismic survey

Date: 1 Jan 2007

Time launched (h): 0737

Time recovered (h): 1615

Number of birds: 4

Lander operations

Latitude: $28^{\circ} 26.929^{\prime} \mathrm{S}$

Longitude: $131^{\circ} 23.345^{\prime} \mathrm{W}$

Date: 1-2 Jan 2006

Time launched (h): 1948

Time recovered $(h): 0100$

Coring operations

Coring too:
Deployment number:
Date $(2006)$
Time launched $(\mathrm{h}):$
Time on bottom $(\mathrm{h})$
Time recovered $(\mathrm{h})$

Tension (lb)

$$
\begin{array}{r}
\text { Surface: } \\
\text { Prior to trip: } \\
\text { On bottom: } \\
\text { Pullout maximum: } \\
\text { Ascending: } \\
\text { Corer length }(\mathrm{ft}): \\
\text { Thermistors: }
\end{array}
$$

Total sediment recovered $(\mathrm{cm})$ :

Weight on trigger/gravity core:

Comments:

Site SPG-6

Latitude: $27^{\circ} 55.000^{\prime} \mathrm{S}$

Longitude: $123^{\circ} 09.692^{\prime} \mathrm{W}$

Water depth (mbsl): 3705

Seismic survey

Date: 4 Jan 2007

Time launched $(\mathrm{h}): 0100$

Time recovered (h): 1004

Number of birds: 4

Coring operations

$$
\begin{array}{r}
\text { Coring tool: } \\
\text { Deployment number: } \\
\text { Date }(2006) \text { : } \\
\text { Time launched }(\mathrm{h}) \text { : } \\
\text { Time on bottom }(\mathrm{h}) \text { : } \\
\text { Time recovered }(\mathrm{h}) \text { : }
\end{array}
$$

\begin{tabular}{|c|c|c|c|c|c|c|}
\hline Gravity & Gravity & Trigger & Piston & Multicore & Trigger & Piston \\
\hline 1 & 2 & 1 & 1 & 1 & 2 & 2 \\
\hline 4 Jan & 4 Jan & 4 Jan & 4 Jan & 4 Jan & 5 Jan & 5 Jan \\
\hline 1053 & 1319 & 1743 & 1743 & 2229 & 0321 & 0321 \\
\hline 1134 & 1406 & 1921 & 1921 & 2353 & 0452 & 0452 \\
\hline 1225 & 1456 & 2123 & 2123 & 0137 & 0647 & 0647 \\
\hline 440 & 403 & 4,255 & 4,255 & 1,200 & 6,000 & 6,000 \\
\hline 1,300 & 1,340 & 9,500 & 9,500 & 6,300 & 10,400 & 10,400 \\
\hline 900 & 1,027 & 5,770 & 5,770 & 5,400 & 6,500 & 6,500 \\
\hline 1,573 & 1,580 & 12,124 & 12,124 & 8,167 & 17,522 & 17,522 \\
\hline 1,420 & - & 9,824 & 9,824 & 7,200 & 11,500 & 11,500 \\
\hline 10 & 10 & 10 & 20 & NA & 10 & 20 \\
\hline 24 & 22 & 63 & 258.5 & $16.83(6 / 9)$ & 84 & 245.5 \\
\hline NA & NA & NA & NA & NA & NA & 4 \\
\hline NA & NA & $8 \mathrm{~Pb}$ rings & No pigs & NA & NA & $\begin{array}{l}2 \text { pigs added to } \\
\text { core bomb }\end{array}$ \\
\hline
\end{tabular}

Tension (lb)

$$
\begin{array}{r}
\text { Surface: } \\
\text { Prior to trip: } \\
\text { On bottom: } \\
\text { Pullout maximum: } \\
\text { Ascending: } \\
\text { Corer length }(\mathrm{ft}): \\
\text { Thermistors: }
\end{array}
$$

Total sediment recovered $(\mathrm{cm})$ :

Weight on trigger/gravity core:

Comments:

$\begin{array}{cccccc}\text { Gravity } & \text { Trigger } & \text { Piston } & \text { Multicore } & \text { Trigger } & \text { Piston } \\ 1 & 1 & 1 & 1 & 2 & 2 \\ 1 \mathrm{Jan} & 1 \mathrm{Jan} & 1 \mathrm{Jan} & 2 \mathrm{Jan} & 2 \mathrm{Jan} & 2 \mathrm{Jan} \\ 1653 & 2029 & 2029 & 0205 & 0713 & 0713 \\ 1742 & 2221 & 2221 & 0351 & 0900 & 0900 \\ 1839 & 0016 & 0016 & 0544 & 1129 & 1129 \\ & & & & & \\ 490 & 5,300 & 5,300 & 1400 & 5,300 & 5,300 \\ - & 10,500 & 10,500 & 7,000 & 10,500 & 10,500 \\ 1,230 & 7,000 & 7,000 & 6,250 & 7,000 & 7,000 \\ 2,170 & 14,862 & 14,862 & 8,748 & 15,403 & 15,403 \\ 1,650 & 11,500 & 11,500 & 7,800 & 11,400 & 11,400 \\ 10 & 10 & 30 & \mathrm{NA} & 10 & 30 \\ 218 & 182.5 & 756 & 24.63(8 / 8) & 161 & 805.5 \\ \mathrm{NA} & \mathrm{NA} & \mathrm{NA} & \mathrm{NA} & \mathrm{NA} & 4 \\ \mathrm{NA} & 8 \mathrm{~Pb} \text { rings } & \mathrm{NA} & \mathrm{NA} & 8 \text { Pb rings } & \mathrm{NA}\end{array}$

Multicore sediment recovered indicates the average of cores recovered. Cores recovered, of eight, indicated in same cell.

Station change between Gravity 1 and Gravity 2. Multicore sediment recovered indicates the average of cores recovered. Cores recovered, of eight, indicated in same cell. 
Table T6 (continued). (Continued on next page.)

Site SPG-7

Latitude: $27^{\circ} 44.4755^{\prime} \mathrm{S}$

Longitude: $117^{\circ} 37.1855^{\prime} \mathrm{W}$

Water depth (mbsl): 3688

Seismic survey

Date: 6 Jan 2007

Time launched (h): 0816

Time recovered $(h): 1450$

Number of birds: 4

Lander operations

Latitude: $27^{\circ} 44.415^{\prime} \mathrm{S}$

Longitude: $117^{\circ} 37.382^{\prime} \mathrm{W}$

Date: 1-7 Jan 2007

Time launched (h): 1728

Time recovered $\mathrm{h}$ ): 0629

Coring operations

Coring tool: Deployment number: Date (2007):

Time launched (h):

Time on bottom (h):

Time recovered (h):

Tension (lb)

Surface:

Prior to trip:

On bottom:

Pullout maximum:

Ascending:

Corer length $(\mathrm{ft})$ :

Total sediment recovered $(\mathrm{cm})$ :

Thermistors:

Weight on trigger/gravity core:

Comments:

Site SPG-9

Latitude: $38^{\circ} 03.6919^{\prime} \mathrm{S}$

Longitude: $133^{\circ} 05.5088^{\prime} \mathrm{W}$

Water depth (mbsl): 4924

Seismic survey

Date: 10-11 Jan 2007

Time launched (h): 2136

Time recovered (h): 0439

Number of birds: 4

Coring operations

$$
\begin{array}{r}
\text { Coring tool: } \\
\text { Deployment number: } \\
\text { Date }(2007) \text { : } \\
\text { Time launched }(h): \\
\text { Time on bottom }(h): \\
\text { Time recovered }(h):
\end{array}
$$

Tension (lb)

Surface:
Prior to trip:
On bottom:
Pullout maximum:
Ascending:

Corer length $(\mathrm{ft})$ :

Total sediment recovered $(\mathrm{cm})$ :

Thermistors:

Weight on trigger/gravity core:

Comments:

$\begin{array}{cccccc}\text { Gravity } & \text { Multi-core } & \text { Trigger } & \text { Piston } & \text { Trigger-gravity } & \text { Jumbo core } \\ 1 & 1 & 1 & 1 & 1 & 1 \\ 6 \text { Jan } & 6 \text { Jan } & 6 \text { Jan } & 6-7 \text { Jan } & 7 \text { Jan } & 7 \text { Jan } \\ 1527 & 1806 & 2217 & 2217 & 0415 & 0822 \\ & 1938 & 2348 & 2348 & 0503 & 0916 \\ 1657 & 2114 & 0138 & 0138 & 0610 & 1034 \\ & & & & & \\ 460 & 1,300 & 4,700 & 4,700 & 560 & 3,400 \\ 1,300 & 6,250 & 9,300 & 9,300 & 1,490 & 8,800 \\ 1,000 & 5,300 & 5,500 & 5,500 & 1,080 & 5,950 \\ 1,793 & 7,881 & 11,100 & 11,100 & 1,990 & 11,800 \\ 483 & 7,000 & 9,500 & 9,500 & 1,650 & 9,000 \\ 10 & \text { NA } & 10 & 20 & 10 & 10 \\ 105.5 & 23.5(6 / 8) & 104.5 & 53.5 & 36.5 & 84.5 \\ \text { NA } & \text { NA } & \text { NA } & 4 & \text { NA } & \text { NA } \\ \text { NA } & \text { NA } & \text { NA } & \text { No pigs } & \text { NA } & \text { No pigs }\end{array}$

Piston 1: Hit basement and bent core sheath, piston core disassembled to recover core liner. Core liner sawed off. Multicore sediment recovered indicates the average of cores recovered. Cores recovered, of eight, indicated in same cell.

$\begin{array}{cccccc}\text { Gravity } & \text { Multicore } & \text { Trigger } & \text { Piston } & \text { Trigger } & \text { Piston } \\ 1 & 1 & 1 & 1 & 2 & 2 \\ 11 \mathrm{Jan} & 11 \mathrm{Jan} & 11 \mathrm{Jan} & 11 \mathrm{Jan} & 12 \mathrm{Jan} & 12 \mathrm{Jan} \\ 0622 & 0847 & 1649 & 1649 & 0035 & 0035 \\ 0718 & 1133 & 1857 & 1857 & 0242 & 0242 \\ 0821 & 1341 & 2124 & 2124 & 0511 & 0511 \\ & & & & \\ 430 & 1,100 & 4,900 & 4,900 & 4,000 & 4,000 \\ 1,500 & 8,000 & 11,500 & 11,500 & 11,000 & 11,000 \\ 1,300 & 7,000 & 8,163 & 8,163 & 8,300 & 8,300 \\ 2,408 & 10,024 & 20,444 & 20,444 & 21,000 & 21,000 \\ 1,850 & - & 12,000 & 12,000 & 12,500 & 12,500 \\ 10 & N A & 10 & 30 & 10 & 20 \\ 175.5 & 28.4(5 / 8) & 139 & 701.5 & 178.5 & 525 \\ \text { NA } & \text { NA } & \text { NA } & \text { NA } & \text { NA } & 4 \\ \text { NA } & \text { NA } & \text { NA } & \text { No pigs } & \text { NA } & \text { NA } \\ \text { Multicore sediment recovered indicates the average of cores recovered. Cores } \\ \text { recovered indicated in same cell }\end{array}$


Table T6 (continued). (Continued on next page.)

Site SPG-10

Latitude: $39^{\circ} 18.6129^{\prime} \mathrm{S}$

Longitude: $139^{\circ} 48.0368^{\prime} \mathrm{W}$

Water depth (mbsl): 5283

Seismic survey

Date: 13 Jan 2007

Time launched (h): 0910

Time recovered $(\mathrm{h}): 1730$

Number of birds: 4

Lander operations

Latitude: $39^{\circ} 18.776^{\prime} \mathrm{S}$

Longitude: $139^{\circ} 48.119^{\prime} \mathrm{W}$

Date: 14 Jan 2007

Time launched (h): 0009

Time recovered $(h): 1520$

Coring operations

Coring tool:
Deployment number:
Date $(2007):$
Time launched $(\mathrm{h}):$
Time on bottom $(\mathrm{h}):$
Time recovered $(\mathrm{h}):$

Multicore
1
13 Jan
1828
2106
2332

Trigger
1
14 Jan
0102
0318
0546

Tension (lb)

$$
\begin{array}{r}
\text { Surface: } \\
\text { Prior to trip: } \\
\text { On bottom: } \\
\text { Pullout maximum: } \\
\text { Ascending: }
\end{array}
$$

Corer length $(\mathrm{ft})$ :

Total sediment recovered $(\mathrm{cm})$ : Thermistors: Weight on trigger/gravity core: Comments:

\section{Site SPG-11}

Latitude: $41^{\circ} 51.1281^{\prime} \mathrm{S}$

Longitude: $153^{\circ} 06.3849^{\prime} \mathrm{W}$

Water depth (mbsl): 5076

Seismic survey

Date: 17 Jan 2007

Time launched (h): 0225

Time recovered (h): 0801

Number of birds: 4

Coring operations

$$
\text { Coring tool: }
$$

Deployment number: Date (2007):

Time launched (h): Time on bottom (h): Time recovered (h):

Tension (lb)

$$
\begin{array}{r}
\text { Surface: } \\
\text { Prior to trip: } \\
\text { On bottom: } \\
\text { Pullout maximum: } \\
\text { Ascending: } \\
\text { Corer length }(\mathrm{ft}):
\end{array}
$$

\begin{tabular}{|c|c|c|c|c|c|}
\hline Gravity & Trigger & Piston & Multicore & $\begin{array}{l}\text { Trigger- } \\
\text { gravity }\end{array}$ & $\begin{array}{l}\text { Trigger- } \\
\text { gravity }\end{array}$ \\
\hline 1 & 1 & 1 & 1 & 1 & 2 \\
\hline 17 Jan & 17 Jan & 17 Jan & 17 Jan & 17-18 Jan & 18 Jan \\
\hline 0845 & 1120 & 1120 & 1729 & 2238 & 0237 \\
\hline 0940 & 1332 & 1332 & 1946 & 0010 & 0402 \\
\hline 1046 & 1557 & 1557 & 2206 & 0142 & 0527 \\
\hline 455 & 4,200 & 4,200 & - & 713 & 700 \\
\hline- & 11,900 & 11,900 & 9,000 & 7,800 & 7,600 \\
\hline 1,300 & 8,800 & 8,800 & 7,400 & 7,300 & 720 \\
\hline 2,063 & 10,600 & 10,600 & 10,068 & 10,000 & 107,400 \\
\hline 1,260 & 8,000 & 8,000 & 9,000 & 8,300 & 8,000 \\
\hline 10 & 10 & 20 & NA & 15 & 15 \\
\hline 12 & 228 & 0 & $35.66(6 / 8)$ & 309 & 298 \\
\hline NA & NA & NA & NA & NA & NA \\
\hline NA & $10 \mathrm{~Pb}$ rings & No pigs & NA & $10 \mathrm{~Pb}$ rings & $10 \mathrm{~Pb}$ ring \\
\hline
\end{tabular}
Total sediment recovered $(\mathrm{cm})$ : Thermistors: Weight on trigger/gravity core: Comments:

$\begin{array}{ccrccrr}1,750 & 4,600 & 4,600 & 4,600 & 4,600 & 4,000 & 4,000 \\ 8,600 & 12,000 & 12,000 & 11,400 & 11,400 & 11,500 & 11,500 \\ 6,700 & 9,000 & 9,000 & 8,500 & 8,500 & 920 & 920 \\ 10,600 & 11,000 & 11,000 & 1,611 & 1,611 & 16,400 & 16,400 \\ 7,500 & 8,500 & 8,500 & 4,965 & 4,965 & 13,000 & 13,000 \\ \text { NA } & 10 & 20 & 10 & 20 & 10 & 20 \\ 37.14(7 / 8) & 226 & 0 & 185 & \text { NA } & \text { NA } & 540 \\ \text { NA } & \text { NA } & \text { NA } & \text { NA } & \text { NA } & \text { NA } & 3 \\ \text { NA } & 9 \text { Pb rings } & \text { No pigs } & \text { 9 Pb rings } & \text { No pigs } & 9 \text { Pb rings } & \text { No pigs }\end{array}$

Piston 1: Wire parted immediately below trigger arm clamp. Trigger core cutter severely cut and torn. Multicore sediment recovered indicates the average of cores recovered. Cores recovered, of eight, indicated in same cell.
Trigger 1: Wire parted immediately below trigger arm clamp. Multicore sediment recovered indicates the average of cores recovered. Cores recovered, of eight, indicated in same cell. 
Table T6 (continued).

\section{Site SPG-12}

Latitude: $45^{\circ} 57.855^{\prime} \mathrm{S}$

Longitude: $163^{\circ} 11.051^{\prime} \mathrm{W}$

Water depth (mbsl): 5306

Seismic survey

Date: 20 Jan 2007

Time launched (h): 0553

Time recovered (h): 1240

Number of birds: 4

Coring operations

Coring tool:
Deployment number:
Date $(2007)$ :
Time launched $(h):$
Time on bottom $(h):$
Time recovered $(h):$

Tension (lb)

Surface:
Prior to trip:
On bottom:
Pullout maximum:
Ascending:

recovered $(\mathrm{cm})$ :
Thermistors:

Weight on trigger/gravity core:

Comments:

$\begin{array}{cc}\begin{array}{c}\text { Trigger- } \\ \text { gravity }\end{array} & \text { Multicore } \\ 1 & 1 \\ 20 \text { Jan } & 20 \text { Jan } \\ 1330 & 1715 \\ 1508 & 1931 \\ 1640 & 2152\end{array}$

\section{Trigger- \\ gravity}

2

20-21 Jan

2229

0015

0154

Trigger-
gravity

3

21 Jan

0359

0525

0655

Trigger-

gravity

4

21 Jan

0727

0901

1032

$\begin{array}{rr}804 & - \\ 8,400 & 9,000 \\ 7,400 & 7,500 \\ 10,400 & 10,500 \\ & 9,500\end{array}$

735
8,500

730

7,500

8,000

8,000

10,470

9,000

15

401

NA

15

380

NA

10,791

8,500

8,000

10,677

9,000

20

20

498

NA

$10 \mathrm{~Pb}$ rings $\mathrm{NA} \quad 10 \mathrm{~Pb}$ rings $10 \mathrm{~Pb}$ rings $10 \mathrm{~Pb}$ rings on GC on GC on GC

Multicore 1: No samples recovered, one tube triggered upon deployment.

$-=$ no data, $\mathrm{NA}=$ not applicable. $\mathrm{TC} / \mathrm{GC}=$ trigger core/growing core 
Table T7. Lander deployments and operations.

\begin{tabular}{|c|c|c|c|c|c|c|c|c|}
\hline Site & $\begin{array}{l}\text { Deployment } \\
\text { time }(\mathrm{h})\end{array}$ & $\begin{array}{l}\text { Recovery } \\
\text { time (h) }\end{array}$ & $\begin{array}{l}\text { Electrode } \\
\text { profiler }\end{array}$ & $\begin{array}{l}\text { Deep } \\
\text { profiler }\end{array}$ & $\begin{array}{l}\text { Incubation } \\
\text { chamber }\end{array}$ & $\begin{array}{l}\text { Bottom } \\
\text { time (h) }\end{array}$ & Measured parameters & Remarks \\
\hline SPG-2 & 1300 & 1402 & & $\mathrm{X}$ & $\mathrm{X}$ & 0 & & Lost weights at surface. No new deployment. \\
\hline SPG-3 & 1037 & 0015 & & $x$ & $x$ & 8 & $\begin{array}{l}4 \times 45 \mathrm{~cm} \text { optode profiles; } \\
\text { chamber incubation }\end{array}$ & \\
\hline SPG-5 & 1949 & 0030 & $x$ & $\mathrm{x}$ & $\mathrm{X}$ & 0 & & $\begin{array}{l}\text { Lost weights when hit seafloor, optode } \\
\text { electronics did not work properly. }\end{array}$ \\
\hline SPG-7 & 1815 & 0818 & $\mathrm{x}$ & $\mathrm{x}$ & $\mathrm{x}$ & 9 & $12 \times 50 \mathrm{~mm}$ electrode profiles & $\begin{array}{l}\text { Optode electronics did not work properly; burn } \\
\text { wire unit took water. }\end{array}$ \\
\hline SPG-10 & 0010 & 1500 & $x$ & $x$ & $x$ & 9 & $8 \times 50 \mathrm{~mm}$ electrode profiles & Optode electronics did not work properly. \\
\hline
\end{tabular}

Time is Universal Time Coordinated.

Table T8. Locations, dates, and times of concentration/temperature/depth recorder (CTD) deployments, and depths of CTD samples.

\begin{tabular}{|c|c|c|c|c|c|}
\hline Station & CTD & Location & Date & Time (h) & $\begin{array}{l}\text { Maximum } \\
\text { depth } \\
\text { (mbsf) }\end{array}$ \\
\hline 1 & 1 & $23^{\circ} 512,046^{\prime} \mathrm{S}, 165^{\circ} 38,637^{\prime} \mathrm{W}$ & 21 Dec 2006 & 2016-2034 & 120 \\
\hline 2 & 2 & $26^{\circ} 03,0888^{\prime} S, 165^{\circ} 53,649^{\prime} \mathrm{W}$ & 24 Dec 2006 & 2044 & 150 \\
\hline 3 & 3 & $27^{\circ} 56,539^{\prime} \mathrm{S}, 148^{\circ} 35,388^{\prime} \mathrm{W}$ & 27 Dec 2006 & $1647-1708$ & 150 \\
\hline 4 & 4 & $26^{\circ} 28,924^{\prime} \mathrm{S}, 137^{\circ} 56,401^{\prime} \mathrm{W}$ & 30 Dec 2006 & 1917-2005 & 200 \\
\hline 5 & 5 & $28^{\circ} 26,780^{\prime} \mathrm{S}, 131^{\circ} 23,423^{\prime} \mathrm{W}$ & $1 \operatorname{Jan} 2007$ & 0604-0634 & 200 \\
\hline 6 & 6 & $27^{\circ} 55,000^{\prime} \mathrm{S}, 123^{\circ} 09,691^{\prime} \mathrm{W}$ & $4 \operatorname{Jan} 2007$ & $1540-1602$ & 200 \\
\hline 7 & 7 & $27^{\circ} 56,539^{\prime} \mathrm{S}, 148^{\circ} 35,388^{\prime} \mathrm{W}$ & $7 \operatorname{Jan} 2007$ & $213-240$ & 220 \\
\hline 9 & 8 & $38^{\circ} 03,691^{\prime} \mathrm{S}, 133^{\circ} 05,507^{\prime} \mathrm{W}$ & $11 \operatorname{Jan} 2007$ & 2154-2214 & 150 \\
\hline 10 & 9 & $39^{\circ} 18,616^{\prime} \mathrm{S}, 139^{\circ} 48,039^{\prime} \mathrm{W}$ & $13 \operatorname{Jan} 2007$ & $0616-634$ & 150 \\
\hline 11 & 10 & $41^{\circ} 51,128^{\prime} \mathrm{S}, 153^{\circ} 06,284^{\prime} \mathrm{W}$ & $15 \operatorname{Jan} 2007$ & 1639-1702 & 150 \\
\hline 12 & 11 & $45^{\circ} 57,866^{\prime} \mathrm{S}, 163^{\circ} 11,051^{\prime} \mathrm{W}$ & $21 \operatorname{Jan} 2007$ & $0225-250$ & 100 \\
\hline
\end{tabular}

Time is Universal Time Coordinated. 
Table T9. Subsample distributions from concentration/temperature/depth recorder (CTD) casts.

\begin{tabular}{|c|c|c|c|c|c|c|c|c|c|c|c|c|c|}
\hline \multirow[b]{2}{*}{ CTD } & \multirow{2}{*}{$\begin{array}{l}\text { Depth } \\
\text { (mbsl) }\end{array}$} & \multicolumn{3}{|c|}{${ }^{15} \mathrm{~N}_{2}$ incubation } & \multicolumn{3}{|c|}{${ }^{15} \mathrm{NH}_{4}$ incubation } & \multicolumn{3}{|c|}{${ }^{15} \mathrm{~N}$-leucene incubation } & \multicolumn{3}{|c|}{ Volume (L) } \\
\hline & & Light & Dark & Control & Light & Dark & Control & Light & Dark & Control & DNA & RNA & Genomic \\
\hline \multirow[t]{5}{*}{1} & SW & & & & & & & & & & & & \\
\hline & 20 & $\mathrm{x}$ & $\mathrm{x}$ & - & $\mathrm{x}$ & $\mathrm{x}$ & $\mathrm{x}$ & $\mathrm{x}$ & $\mathrm{x}$ & $\mathrm{x}$ & & & \\
\hline & 40 & $\mathrm{x}$ & $\mathrm{x}$ & - & $\mathrm{x}$ & $\mathrm{x}$ & $\mathrm{x}$ & $\mathrm{x}$ & $\mathrm{x}$ & $\mathrm{x}$ & 2 & & \\
\hline & 60 & $\mathrm{x}$ & $\mathrm{x}$ & - & $\mathrm{x}$ & $\mathrm{x}$ & $\mathrm{x}$ & $\mathrm{x}$ & $\mathrm{x}$ & $\mathrm{x}$ & 1 & 3 & \\
\hline & 100 & $\mathrm{x}$ & $\mathrm{x}$ & - & $\mathrm{x}$ & $\mathrm{x}$ & $\mathrm{x}$ & $\mathrm{x}$ & $\mathrm{x}$ & $\mathrm{x}$ & 1 & 3 & \\
\hline \multirow[t]{4}{*}{2} & 0 & $\mathrm{x}$ & $\mathrm{x}$ & - & $\mathrm{x}$ & $\mathrm{x}$ & - & $\mathrm{x}$ & $\mathrm{x}$ & - & 3 & 10 & \\
\hline & 60 & $\mathrm{x}$ & $\mathrm{x}$ & - & $\mathrm{x}$ & $\mathrm{x}$ & - & $\mathrm{x}$ & $\mathrm{x}$ & - & & & \\
\hline & 110 & $\mathrm{x}$ & $\mathrm{x}$ & - & $\mathrm{x}$ & $\mathrm{x}$ & - & $\mathrm{x}$ & $\mathrm{x}$ & - & 2 & 5 & \\
\hline & 150 & $x$ & $x$ & - & $x$ & $x$ & - & $\mathrm{x}$ & $\mathrm{x}$ & - & 2 & 10 & \\
\hline \multirow[t]{4}{*}{3} & 0 & $\mathrm{x}$ & $\mathrm{x}$ & $x$ & $\mathrm{x}$ & $\mathrm{x}$ & $\mathrm{x}$ & $\mathrm{x}$ & $\mathrm{x}$ & $\mathrm{X}$ & 5 & 10 & \\
\hline & 40 & $\mathrm{x}$ & $\mathrm{x}$ & $x$ & - & - & - & - & - & - & $2+2.5$ & 10 & \\
\hline & 80 & $\mathrm{x}$ & $\mathrm{x}$ & $x$ & - & - & - & - & - & - & 1 & 10 & \\
\hline & 120 & $\mathrm{x}$ & $x$ & - & $x$ & $x$ & $x$ & $x$ & $x$ & $x$ & 2.25 & 7 & 5 \\
\hline \multirow[t]{4}{*}{4} & 0 & $x$ & $x$ & $x$ & $x$ & $x$ & $x$ & $x$ & $x$ & $x$ & 4 & 10 & \\
\hline & 80 & $x$ & $x$ & - & - & - & - & - & - & - & 1 & 10 & \\
\hline & 120 & $x$ & $x$ & - & - & - & - & - & - & - & 3 & 10 & \\
\hline & 150 & $x$ & $x$ & - & $x$ & $x$ & $x$ & $x$ & $x$ & $x$ & 4 & 7 & 5 \\
\hline \multirow[t]{4}{*}{5} & 0 & $x$ & $x$ & $x$ & - & - & - & - & - & - & 4 & 10 & \\
\hline & 100 & $x$ & $x$ & - & - & - & - & - & - & - & 2.5 & & \\
\hline & 145 & $x$ & $x$ & - & - & - & - & - & - & - & 4 & 10 & 5 \\
\hline & 200 & $x$ & $x$ & - & - & - & - & - & - & - & & & \\
\hline \multirow[t]{4}{*}{6} & 0 & $x$ & $x$ & $x$ & $x$ & $x$ & $x$ & $x$ & $x$ & $x$ & 2.7 & 10 & \\
\hline & 80 & $x$ & $x$ & - & - & - & - & - & - & - & 3 & & \\
\hline & 120 & $x$ & $x$ & - & - & - & - & - & - & - & 4 & & \\
\hline & 150 & $x$ & $x$ & - & $x$ & $x$ & $x$ & $x$ & $x$ & $x$ & 1.5 & 9.5 & 5 \\
\hline \multirow[t]{5}{*}{7} & 0 & $x$ & $x$ & $x$ & - & - & - & - & - & - & 5 & 10 & \\
\hline & 100 & $x$ & $x$ & - & - & - & - & - & - & - & & & \\
\hline & 175 & $x$ & $x$ & - & - & - & - & - & - & - & 2.5 & & \\
\hline & 200 & $x$ & $x$ & - & - & - & - & - & - & - & 1 & 10 & 5 \\
\hline & 220 & $x$ & $x$ & - & - & - & - & - & - & - & $1.25+2.5$ & 4.25 & \\
\hline \multirow[t]{5}{*}{8} & SW & $x$ & $x$ & $x$ & $x$ & $x$ & $x$ & $x$ & $x$ & $x$ & & & \\
\hline & SWS & $x$ & $x$ & $x$ & - & - & - & - & - & - & 5 & 10 & \\
\hline & 40 & $x$ & $x$ & - & - & - & - & - & - & - & $2^{*}$ & 10 & \\
\hline & 80 & $x$ & $x$ & - & - & - & - & - & - & - & $4^{*}$ & 8 & \\
\hline & 110 & $x$ & $x$ & - & $x$ & $x$ & $x$ & $x$ & $x$ & $x$ & $2^{*}$ & 10 & 5 \\
\hline \multirow[t]{5}{*}{9} & SW & $x$ & $x$ & $x$ & $x$ & $x$ & $x$ & $x$ & $x$ & $x$ & 3 & 10 & \\
\hline & SWS & $x$ & $x$ & $x$ & - & - & - & - & - & - & & & \\
\hline & 40 & $x$ & $x$ & - & - & - & - & - & - & - & 2.4 & 7.5 & \\
\hline & 80 & $x$ & $x$ & - & - & - & - & - & - & - & 2.5 & 7.5 & \\
\hline & 110 & $x$ & $x$ & - & $x$ & $x$ & $x$ & $x$ & $x$ & $x$ & 2.2 & 10 & 5 \\
\hline \multirow[t]{6}{*}{10} & SW & $x$ & $x$ & $x$ & $x$ & $x$ & $x$ & $x$ & $x$ & $x$ & 3 & & \\
\hline & 18 & - & - & - & $x$ & $x$ & $x$ & $x$ & $x$ & $x$ & $2^{*}$ & & \\
\hline & 40 & $x$ & $x$ & - & - & - & - & - & - & - & $2.5^{*}$ & 10 & \\
\hline & 60 & $x$ & $x$ & - & $x$ & $x$ & $x$ & $x$ & $x$ & $x$ & $2^{*}$ & & \\
\hline & 80 & - & - & - & - & - & - & - & - & - & $1^{*}$ & 10 & 5 \\
\hline & 100 & $x$ & $x$ & - & $x$ & $x$ & $x$ & $x$ & $x$ & $x$ & $4.5^{*}$ & 10 & \\
\hline 11 & SW & $x$ & $x$ & $x$ & $x$ & $x$ & $x$ & $x$ & $x$ & $x$ & 1 & & \\
\hline & 40 & $x$ & $x$ & - & - & - & - & - & - & - & & 6.2 & 4 \\
\hline & 80 & $x$ & $x$ & - & - & - & - & - & - & - & 1 & 4.5 & \\
\hline & 100 & $x$ & $x$ & - & $x$ & $x$ & $x$ & $x$ & $x$ & $x$ & & & \\
\hline
\end{tabular}

$-=$ no sample. $S W=$ surface water, SWS = seawater supply line. 
Table T10. Argo float deployment data.

\begin{tabular}{|c|c|c|c|c|}
\hline $\begin{array}{l}\text { Deployment } \\
\text { order }\end{array}$ & $\begin{array}{c}\text { Serial } \\
\text { number }\end{array}$ & Date & $\begin{array}{l}\text { Time } \\
\text { (h) }\end{array}$ & Location \\
\hline 1 & 2360 & 22 Dec 2006 & 1720 & $24^{\circ} 32.194^{\prime} \mathrm{S}, 163^{\circ} 00.479^{\prime} \mathrm{W}$ \\
\hline 2 & 2361 & 23 Dec 2006 & 0844 & $25^{\circ} 16.339^{\prime} \mathrm{S}, 159^{\circ} 59.904^{\prime} \mathrm{W}$ \\
\hline 3 & 2632 & 25 Dec 2006 & 0325 & $26^{\circ} 03.178^{\prime} \mathrm{S}, 156^{\circ} 52.993^{\prime} \mathrm{W}$ \\
\hline 4 & 2609 & 31 Dec 2006 & 1532 & $27^{\circ} 15^{\prime} \mathrm{S}, 135^{\circ} 00^{\prime} \mathrm{W}$ \\
\hline 5 & 2617 & $1 \operatorname{Jan} 2007$ & 0100 & $27^{\circ} 47.73^{\prime} \mathrm{S}, 132^{\circ} 54.98^{\prime} \mathrm{W}$ \\
\hline 6 & 2633 & $2 \operatorname{Jan} 2007$ & 2235 & $28^{\circ} 16^{\prime} \mathrm{S}, 129^{\circ} 00^{\prime} \mathrm{W}$ \\
\hline 7 & 2634 & $3 \operatorname{Jan} 2007$ & 0740 & $28^{\circ} 07.37^{\prime} \mathrm{S}, 127^{\circ} 02.47^{\prime} \mathrm{W}$ \\
\hline 8 & 2635 & $5 \operatorname{Jan} 2007$ & 1235 & $27^{\circ} 54.78^{\prime} \mathrm{S}, 122^{\circ} 00^{\prime} \mathrm{W}$ \\
\hline 9 & 2636 & $5 \operatorname{Jan} 2007$ & 2150 & $27^{\circ} 54.4^{\prime} \mathrm{S}, 119^{\circ} 55.8^{\prime} \mathrm{W}$ \\
\hline 10 & 2637 & $7 \operatorname{Jan} 2007$ & 1110 & $27^{\circ} 44.65^{\prime} \mathrm{S}, 117^{\circ} 37.43^{\prime} \mathrm{W}$ \\
\hline 11 & 2638 & 7 Jan 2007 & 2042 & $28^{\circ} 54^{\prime} \mathrm{S}, 119^{\circ} 18^{\prime} \mathrm{W}$ \\
\hline 12 & 2639 & $8 \operatorname{Jan} 2007$ & 0436 & $29^{\circ} 53.50^{\prime} \mathrm{S}, 120^{\circ} 42.28^{\prime} \mathrm{W}$ \\
\hline
\end{tabular}

Time is Universal Time Coordinated. 
Table T11. Core recovery and core flow for recovered piston, trigger, and gravity cores.

\begin{tabular}{|c|c|c|c|c|c|}
\hline Site & Core & Location & $\begin{array}{l}\text { Water depth } \\
\text { (mbsl) }\end{array}$ & $\begin{array}{l}\text { Core length } \\
\text { (m) }\end{array}$ & Core flow paths \\
\hline \multirow[t]{5}{*}{ SPG-1 } & G1 & $23^{\circ} 51.040^{\prime} \mathrm{S}, 165^{\circ} 38.640^{\prime} \mathrm{W}$ & 5696 & 2.00 & O2, MST \\
\hline & $\mathrm{T} 1$ & $23^{\circ} 51.044^{\prime} \mathrm{S}, 165^{\circ} 38.638^{\prime} \mathrm{W}$ & 5697 & 2.11 & $\mathrm{O} 2, \mathrm{MST}$ \\
\hline & P1 & $23^{\circ} 51.044^{\prime} \mathrm{S}, 165^{\circ} 38.638^{\prime} \mathrm{W}$ & 5697 & 7.79 & IW, MBIO, MST \\
\hline & $\mathrm{T} 2$ & $23^{\circ} 51.05^{\prime} \mathrm{S}, 165^{\circ} 38.635^{\prime} \mathrm{W}$ & 5694 & 2.81 & MST \\
\hline & P2 & $23^{\circ} 51.05^{\prime} \mathrm{S}, 165^{\circ} 38.635^{\prime} \mathrm{W}$ & 5694 & 7.80 & THERM, MST \\
\hline \multirow[t]{4}{*}{ SPG-2 } & $\mathrm{T} 1$ & $26^{\circ} 3.089^{\prime} \mathrm{S}, 156^{\circ} 53.646^{\prime} \mathrm{W}$ & 5125 & 8.16 & MST \\
\hline & P1 & $26^{\circ} 3.089^{\prime} \mathrm{S}, 156^{\circ} 53.646^{\prime} \mathrm{W}$ & 5125 & 2.60 & IW, MBIO, MST \\
\hline & $\mathrm{T} 2$ & $26^{\circ} 3.069^{\prime} \mathrm{S}, 156^{\circ} 53.648^{\prime} \mathrm{W}$ & 5126 & 2.52 & MST \\
\hline & P2 & $26^{\circ} 3.069^{\prime} \mathrm{S}, 156^{\circ} 53.648^{\prime} \mathrm{W}$ & 5126 & 8.20 & O2, THERM, MST \\
\hline \multirow[t]{4}{*}{ SPG-3 } & $\mathrm{T} 1$ & $27^{\circ} 56.539^{\prime} \mathrm{S}, 148^{\circ} 35.388^{\prime} \mathrm{W}$ & 4850 & 2.11 & MST \\
\hline & P1 & $27^{\circ} 56.539^{\prime} \mathrm{S}, 148^{\circ} 35.388^{\prime} \mathrm{W}$ & 4850 & 5.34 & IW, MBIO, MST \\
\hline & $\mathrm{T} 2$ & $27^{\circ} 56.538^{\prime} \mathrm{S}, 148^{\circ} 35.388^{\prime} \mathrm{W}$ & 4846 & 0.00 & \\
\hline & P2 & $27^{\circ} 56.538^{\prime} \mathrm{S}, 148^{\circ} 35.388^{\prime} \mathrm{W}$ & 4846 & 4.30 & O2, THERM, MST \\
\hline \multirow[t]{5}{*}{ SPG-4 } & G1 & $26^{\circ} 28.929^{\prime} \mathrm{S}, 137^{\circ} 56.402^{\prime} \mathrm{W}$ & 4285 & 1.91 & MST \\
\hline & $\mathrm{T} 1$ & $26^{\circ} 28.924^{\prime} \mathrm{S}, 137^{\circ} 56.402^{\prime} \mathrm{W}$ & 4285 & 1.11 & RHIZ, MST \\
\hline & P1 & $26^{\circ} 28.924^{\prime} \mathrm{S}, 137^{\circ} 56.402^{\prime} \mathrm{W}$ & 4285 & 7.24 & IW, MBIO, MST \\
\hline & $\mathrm{T} 2$ & $26^{\circ} 28.923^{\prime} \mathrm{S}, 137^{\circ} 56.402^{\prime} \mathrm{W}$ & 4285 & 2.56 & MST \\
\hline & P2 & $26^{\circ} 28.923^{\prime} \mathrm{S}, 137^{\circ} 56.402^{\prime} \mathrm{W}$ & 4285 & 6.22 & O2, THERM, MST \\
\hline \multirow[t]{5}{*}{ SPG-5 } & G1 & $28^{\circ} 26.278^{\prime} \mathrm{S}, 131^{\circ} 23.422^{\prime} \mathrm{W}$ & 4222 & 2.18 & MST \\
\hline & $\mathrm{T} 1$ & $28^{\circ} 26.754^{\prime} \mathrm{S}, 131^{\circ} 23.422^{\prime} \mathrm{W}$ & 4222 & 2.12 & MST \\
\hline & P1 & $28^{\circ} 26.754^{\prime} \mathrm{S}, 131^{\circ} 23.422^{\prime} \mathrm{W}$ & 4222 & 7.88 & IW, MBIO, MST \\
\hline & $\mathrm{T} 2$ & $28^{\circ} 26.780^{\prime} \mathrm{S}, 131^{\circ} 23.423^{\prime} \mathrm{W}$ & 4221 & 1.61 & MST \\
\hline & P2 & $28^{\circ} 26.780^{\prime} \mathrm{S}, 131^{\circ} 23.423^{\prime} \mathrm{W}$ & 4221 & 7.90 & O2, THERM, MST \\
\hline \multirow[t]{6}{*}{ SPG-6 } & G1 & $27^{\circ} 54.968^{\prime} \mathrm{S}, 123^{\circ} 12.856^{\prime} \mathrm{W}$ & 3705 & 0.24 & MST \\
\hline & G2 & $27^{\circ} 55.000^{\prime} \mathrm{S}, 123^{\circ} 09.692^{\prime} \mathrm{W}$ & 3738 & 0.22 & MST \\
\hline & $\mathrm{T} 1$ & $27^{\circ} 55.499^{\prime} \mathrm{S}, 123^{\circ} 09.692^{\prime} \mathrm{W}$ & 3738 & 0.63 & MST \\
\hline & P1 & $27^{\circ} 55.499^{\prime} \mathrm{S}, 123^{\circ} 09.692^{\prime} \mathrm{W}$ & 3738 & 2.58 & O2, THERM, MST \\
\hline & $\mathrm{T} 2$ & $27^{\circ} 55.005^{\prime} \mathrm{S}, 123^{\circ} 09.692^{\prime} \mathrm{W}$ & 3738 & 0.85 & MST \\
\hline & P2 & $27^{\circ} 55.005^{\prime} \mathrm{S}, 123^{\circ} 09.692^{\prime} \mathrm{W}$ & 3738 & 1.45 & IW, MBIO, MST \\
\hline \multirow[t]{5}{*}{ SPG-7 } & G1 & $27^{\circ} 44.468^{\prime} \mathrm{S}, 117^{\circ} 37.184^{\prime} \mathrm{W}$ & 3688 & 1.96 & MST \\
\hline & $\mathrm{T} 1$ & $27^{\circ} 44.475^{\prime} \mathrm{S}, 117^{\circ} 37.185^{\prime} \mathrm{W}$ & 3688 & 1.05 & IW, MBIO \\
\hline & P1 & $27^{\circ} 44.475^{\prime} \mathrm{S}, 117^{\circ} 37.185^{\prime} \mathrm{W}$ & 3688 & 0.33 & MST \\
\hline & $\mathrm{J} 1$ & $27^{\circ} 44.476^{\prime} \mathrm{S}, 117^{\circ} 37.186^{\prime} \mathrm{W}$ & 3688 & 0.85 & MST \\
\hline & TG1 & $27^{\circ} 44.471^{\prime} \mathrm{S}, 117^{\circ} 37.187^{\prime} \mathrm{W}$ & 3688 & 0.36 & MST \\
\hline \multirow[t]{5}{*}{ SPG-9 } & G1 & $38^{\circ} 3.690^{\prime} \mathrm{S}, 133^{\circ} 05.506^{\prime} \mathrm{W}$ & 4924 & 1.76 & MST \\
\hline & $\mathrm{T} 1$ & $38^{\circ} 3.691^{\prime} \mathrm{S}, 133^{\circ} 05.507^{\prime} \mathrm{W}$ & 4924 & 1.33 & MST \\
\hline & P1 & $38^{\circ} 3.691^{\prime} \mathrm{S}, 133^{\circ} 05.507^{\prime} \mathrm{W}$ & 4924 & 6.98 & IW, MBIO, MST \\
\hline & $\mathrm{T} 2$ & $38^{\circ} 3.692^{\prime} \mathrm{S}, 133^{\circ} 05.509^{\prime} \mathrm{W}$ & 4924 & 1.60 & MST \\
\hline & P2 & $38^{\circ} 3.692^{\prime} \mathrm{S}, 133^{\circ} 05.509^{\prime} \mathrm{W}$ & 4924 & 5.20 & O2, THERM, MST \\
\hline \multirow[t]{5}{*}{ SPG-10 } & $\mathrm{T} 1$ & $39^{\circ} 18.619^{\prime} \mathrm{S}, 139^{\circ} 48.035^{\prime} \mathrm{W}$ & 5283 & 1.26 & MST \\
\hline & $\mathrm{T} 2$ & $39^{\circ} 18.617^{\prime} \mathrm{S}, 139^{\circ} 48.038^{\prime} \mathrm{W}$ & 5283 & 1.85 & MST \\
\hline & P2 & $39^{\circ} 18.617^{\prime} \mathrm{S}, 139^{\circ} 48.038^{\prime} \mathrm{W}$ & 5283 & 5.38 & IW, MBIO, MST \\
\hline & T3 & $39^{\circ} 18.613^{\prime} \mathrm{S}, 139^{\circ} 48.034^{\prime} \mathrm{W}$ & 5283 & 2.33 & MST \\
\hline & P3 & $39^{\circ} 18.613^{\prime} \mathrm{S}, 139^{\circ} 48.034^{\prime} \mathrm{W}$ & 5283 & 5.29 & O2, THERM, MST \\
\hline \multirow[t]{4}{*}{ SPG-11 } & G1 & $41^{\circ} 51.128^{\prime} \mathrm{S}, 153^{\circ} 06.384^{\prime} \mathrm{W}$ & 5076 & 0.12 & MST \\
\hline & $\mathrm{T} 1$ & $41^{\circ} 51.127^{\prime} \mathrm{S}, 153^{\circ} 06.384^{\prime} \mathrm{W}$ & 5076 & 2.28 & MST \\
\hline & TG1 & $41^{\circ} 51.127^{\prime} \mathrm{S}, 153^{\circ} 06.384^{\prime} \mathrm{W}$ & 5076 & 3.07 & IW, MBIO \\
\hline & TG2 & $41^{\circ} 51.127^{\prime} \mathrm{S}, 153^{\circ} 06.384^{\prime} \mathrm{W}$ & 5076 & 2.98 & O2, THERM, MST \\
\hline \multirow[t]{4}{*}{ SPG-12 } & TG1 & $45^{\circ} 57.853^{\prime} \mathrm{S}, 163^{\circ} 11.051^{\prime} \mathrm{W}$ & 5307 & 4.07 & IW, MBIO \\
\hline & TG2 & $45^{\circ} 57.853^{\prime} \mathrm{S}, 163^{\circ} 11.051^{\prime} \mathrm{W}$ & 5307 & 3.80 & O2, THERM, MST \\
\hline & TG3 & $45^{\circ} 57.850^{\prime} \mathrm{S}, 163^{\circ} 11.052^{\prime} \mathrm{W}$ & 5314 & 4.10 & O2, THERM, MST \\
\hline & TG4 & $45^{\circ} 57.853^{\prime} \mathrm{S}, 163^{\circ} 11.051^{\prime} \mathrm{W}$ & 5314 & 4.98 & IW, MBIO, MST \\
\hline
\end{tabular}

$\mathrm{O} 2$ = oxygen measurement, MST = sedimentological and physical properties measurements, IW = interstitial water sampling, $\mathrm{MBIO}=$ microbiological subsampling, THERM = thermal conductivity measurement, $\mathrm{RHIZ}=$ Rhizon sampling. 
Table T12. Summary of geophysical measurements.

\begin{tabular}{cccccccc}
\hline & Location & $\begin{array}{c}\text { Water } \\
\text { depth } \\
(\mathrm{mbsl})\end{array}$ & $\begin{array}{c}\text { Crustal } \\
\text { age } \\
(\mathrm{Ma})\end{array}$ & Chron & $\begin{array}{c}\text { Spreading rate } \\
(\mathrm{km} / \mathrm{m} . \mathrm{y} ., \text { half } \\
\text { rate })\end{array}$ & $\begin{array}{c}\text { Sediment } \\
\text { thickness } \\
(\mathrm{m})\end{array}$ & $\begin{array}{c}\text { Heat flow } \\
\left(\mathrm{mW} / \mathrm{m}^{2}\right)\end{array}$ \\
\hline SPG-1 & $23^{\circ} 51.046^{\prime} \mathrm{S}, 165^{\circ} 38.636^{\prime} \mathrm{W}$ & 5697 & $\sim 100$ & $34 \mathrm{n}$ & $?$ & 71 & - \\
SPG-2 & $26^{\circ} 03.090^{\prime} \mathrm{S}, 156^{\circ} 53.647^{\prime} \mathrm{W}$ & 5127 & $\sim 100$ & $34 \mathrm{n}$ & $?$ & 17 & 54 \\
SPG-3 & $27^{\circ} 56.539^{\prime} \mathrm{S}, 148^{\circ} 35.388^{\prime} \mathrm{W}$ & 4852 & 70 & C31r & 33 & 6 & 92 \\
SPG-4 & $26^{\circ} 28.924^{\prime} \mathrm{S}, 137^{\circ} 56.402^{\prime} \mathrm{W}$ & 4285 & 33.5 & C13n & 65 & 10 & 81 \\
SPG-5 & $28^{\circ} 26.784^{\prime} \mathrm{S}, 131^{\circ} 23.422^{\prime} \mathrm{W}$ & 4221 & 24 & C7n.1r & 71 & 17 & 77 \\
SPG-6 & $27^{\circ} 55.000^{\prime} \mathrm{S}, 123^{\circ} 09.692^{\prime} \mathrm{W}$ & 3738 & 13.5 & C5ABn & 85 & 15 & 65 \\
SPG-7 & $27^{\circ} 44.483^{\prime} \mathrm{S}, 117^{\circ} 37.186^{\prime} \mathrm{W}$ & 3688 & 6.1 & C3An.1n & 58 & $<3$ & 36 \\
SPG-9 & $38^{\circ} 03.690^{\prime} \mathrm{S}, 133^{\circ} 05.507^{\prime} \mathrm{W}$ & 4925 & 39 & C18n.2n & 95 & 20 & 46 \\
SPG-10 & $39^{\circ} 18.617^{\prime} \mathrm{S}, 139^{\circ} 48.036^{\prime} \mathrm{W}$ & 5283 & 58 & C25r & 28 & 22 & 18 \\
SPG-11 & $41^{\circ} 51.128^{\prime} \mathrm{S}, 153^{\circ} 06.382^{\prime} \mathrm{W}$ & 5076 & 75 & C33n & 59 & 67 & - \\
SPG-12 & $45^{\circ} 57.854^{\prime} \mathrm{S}, 163^{\circ} 11.053^{\prime} \mathrm{W}$ & 5306 & 73 & C32n.2n & 53 & 130 & - \\
\hline
\end{tabular}

Crustal ages determined with Gradstein et al. (2004) geomagnetic polarity timescale. Crustal age for Sites SPG-1 and SPG-2 estimated based on tectonic reconstruction of Larson et al. (2002). ? = unknown, $-=$ no data. 
Table T13. Overview of concentration/temperature/depth recorder (CTD) casts and results. (Continued on next page.)

\begin{tabular}{|c|c|c|c|c|c|c|c|c|c|c|c|c|}
\hline Station & CTD & Date & $\begin{array}{l}\text { Time } \\
\text { (h) }\end{array}$ & Location & $\begin{array}{l}\text { Depth } \\
\text { (mbsl) }\end{array}$ & Bottles & Pressure & $\begin{array}{c}\text { Temperature } \\
\left(\mathrm{C}^{\circ}\right)\end{array}$ & $\begin{array}{l}\text { Conductivity } \\
(\mathrm{mS} / \mathrm{cm})\end{array}$ & $\begin{array}{l}\text { Salinity } \\
\text { (psu) }\end{array}$ & $\begin{array}{l}\text { Chlorophyll } \\
(\mu \mathrm{g} / \mathrm{L})\end{array}$ & Comment \\
\hline \multirow[t]{4}{*}{1} & 1 & 21 Dec 2006 & 2016-2034 & $23^{\circ} 51.046^{\prime} \mathrm{S}, 165^{\circ} 38.637^{\prime} \mathrm{W}$ & 20 & $19-24$ & 21.2 & 23.2 & 5.2 & 35.6 & - & \\
\hline & & & & & 40 & $13-18$ & 40.6 & 23.1 & 5.19 & 35.57 & - & \\
\hline & & & & & 60 & $7-12$ & 59.1 & 21.9 & 5 & 35.59 & - & \\
\hline & & & & & 100 & $1-6$ & 101.0 & 19.68 & 4.84 & 35.61 & - & $\mathrm{Chl}$ maximum \\
\hline \multirow[t]{4}{*}{2} & 2 & 24 Dec 2006 & 2044 & $26^{\circ} 03.0888^{\prime} \mathrm{S}, 165^{\circ} 53.649^{\prime} \mathrm{W}$ & SW & & & & & & & \\
\hline & & & & & 60 & $17-24$ & 62.7 & 19.8 & 4.8 & 35.59 & 0.15 & \\
\hline & & & & & 110 & $9-16$ & 112.5 & 18.13 & 4.6 & 35.57 & 0.392 & Chl maximum \\
\hline & & & & & 150 & $1-8$ & 152.7 & 17.5 & 4.6 & 35.6 & 0.05 & \\
\hline \multirow[t]{5}{*}{3} & 3 & 27 Dec 2006 & $1647-1708$ & $27^{\circ} 56.539^{\prime} \mathrm{S}, 148^{\circ} 35.388^{\prime} \mathrm{W}$ & SW & & & & & & & \\
\hline & & & & & 40 & $18-24$ & 42.5 & 20.6 & 4.9 & 35.5 & - & \\
\hline & & & & & 80 & $11-17$ & 82.5 & 19.5 & 4.8 & 35.5 & - & \\
\hline & & & & & 120 & $1-10$ & 122.5 & 18.5 & 4.7 & 35.5 & 0.36 & Chl maximum \\
\hline & & & & & Lander & & & & & & & \\
\hline \multirow[t]{4}{*}{4} & 4 & 30 Dec 2006 & 1917-2005 & $26^{\circ} 28.924^{\prime} \mathrm{S}, 137^{\circ} 56.401^{\prime} \mathrm{W}$ & SW & & & & & & & \\
\hline & & & & & 80 & $17-24$ & 82.5 & 20.8 & 4.94 & 35.5 & 0.085 & \\
\hline & & & & & 120 & $11-16$ & 122.2 & 19.83 & 4.84 & 35.5 & 0.12 & \\
\hline & & & & & 150 & $1-10$ & 152.0 & 19.37 & 4.79 & 35.5 & 0.22 & Chl maximum \\
\hline \multirow[t]{4}{*}{5} & 5 & 1 Apr 2007 & 0604-0634 & $28^{\circ} 26.780^{\prime} \mathrm{S}, 131^{\circ} 23.423^{\prime} \mathrm{W}$ & sW & & & & & & & \\
\hline & & & & & 100 & $17-24$ & 102.4 & 19.3 & 4.7 & 35.5 & 0.085 & \\
\hline & & & & & 145 & $7-16$ & 146.8 & 18.1 & 4.65 & 35.39 & 0.354 & Chl maximum \\
\hline & & & & & 200 & $1-6$ & 201.9 & 16.9 & 4.5 & 35.3 & 0.134 & \\
\hline \multirow[t]{4}{*}{6} & 6 & 1 Apr 2007 & $1540-1602$ & $27^{\circ} 55.000^{\prime} \mathrm{S}, 123^{\circ} 09.691^{\prime} \mathrm{W}$ & sw & & & & & & & \\
\hline & & & & & 80 & $18-24$ & 82.2 & 19.4 & 4.56 & 35.26 & 0.07 & \\
\hline & & & & & 120 & $11-17$ & 122.7 & 18.125 & 4.655 & 35.381 & 0.028 & Still maximum \\
\hline & & & & & 150 & $1-10$ & 152.0 & 17.31 & 4.8 & 35.5 & $0.293-0.317$ & Chl maximum \\
\hline \multirow[t]{5}{*}{7} & 7 & $7 \operatorname{Jan} 2007$ & $0213-0240$ & $27^{\circ} 56.539^{\prime} \mathrm{S}, 148^{\circ} 35.388^{\prime} \mathrm{W}$ & sW & & & & & & & \\
\hline & & & & & 100 & $23-24$ & 103.0 & 21.43 & 5.06 & 35.9 & 0.048 & \\
\hline & & & & & 175 & $17-22$ & 178.0 & 19.5 & 4.8 & 35.6 & 0.28 & Chl maximum \\
\hline & & & & & 200 & $8-17$ & 203.3 & 18.76 & 4.7 & 35.5 & 0.27 & Chl maximum \\
\hline & & & & & 220 & $1-7$ & 222.9 & 18.39 & 4.69 & 35.42 & 0.176 & Chl maximum \\
\hline \multirow[t]{4}{*}{9} & 8 & 11 Jan 2007 & $2154-2214$ & $38^{\circ} 03.691^{\prime} \mathrm{S}, 133^{\circ} 05.507^{\prime} \mathrm{W}$ & sw & & & & & & & \\
\hline & & & & & 40 & $18-24$ & 42.3 & 13.71 & 4.09 & 34.29 & - & \\
\hline & & & & & 80 & $11-17$ & 178.0 & 19.5 & 4.8 & 35.6 & 0.28 & \\
\hline & & & & & 110 & $1-10$ & 111.8 & 11.5 & 3.88 & 34.3 & 0.297 & Chl maximum \\
\hline \multirow[t]{6}{*}{10} & 9 & $13 \operatorname{Jan} 2007$ & $0616-0634$ & $39^{\circ} 18.616^{\prime} \mathrm{S}, 139^{\circ} 48.039^{\prime} \mathrm{W}$ & sw & & & & & & & \\
\hline & & & & & 18 & 24 & 20.4 & 17.5 & 4.4 & 34.24 & - & Direct over thermocline \\
\hline & & & & & 40 & $18-23$ & 43.5 & 13.6 & 4.08 & 34.36 & 0.39 & Upper chl maximum \\
\hline & & & & & 60 & 17 & 62.6 & 12.45 & 3.98 & 34.35 & 0.33 & Chl minimum \\
\hline & & & & & 80 & $11-16$ & 82.4 & 11.67 & 3.9 & 34.33 & 0.34 & Still chl maximum \\
\hline & & & & & 100 & $1-10$ & 103.2 & 11.2 & 3.89 & 34.36 & 0.396 & Chl maximum \\
\hline \multirow[t]{6}{*}{11} & 10 & $15 \operatorname{Jan} 2007$ & & $41^{\circ} 51.128^{\prime} \mathrm{S}, 153^{\circ} 06.284^{\prime} \mathrm{W}$ & sw & & & & & & & \\
\hline & & & & & 20 & 24 & 23.4 & 15.59 & 4.295 & 34.5 & - & Above thermocline \\
\hline & & & & & 40 & $18-23$ & 43.0 & 12.4 & 4.007 & 34.484 & 0.25 & Small upper chl maximum \\
\hline & & & & & 60 & 17 & 62.8 & 11.314 & 3.885 & 34.48 & 0.3 & Chl minimum \\
\hline & & & & & 80 & $8-16$ & 83.3 & 10.87 & 3.84 & 34.45 & 0.345 & Chl maximum \\
\hline & & & & & 100 & $1-7$ & 103.0 & 10.5 & 3.81 & 34.47 & 0.344 & Lower end of chl maximum \\
\hline
\end{tabular}


Table T13 (continued)

\begin{tabular}{|c|c|c|c|c|c|c|c|c|c|c|c|c|}
\hline Station & CTD & Date & $\begin{array}{l}\text { Time } \\
(h)\end{array}$ & Location & $\begin{array}{l}\text { Depth } \\
\text { (mbsl) }\end{array}$ & Bottles & Pressure & $\begin{array}{l}\text { Temperature } \\
\left(\mathrm{C}^{\circ}\right)\end{array}$ & $\begin{array}{l}\text { Conductivity } \\
(\mathrm{mS} / \mathrm{cm})\end{array}$ & $\begin{array}{c}\text { Salinity } \\
\text { (psu) }\end{array}$ & $\begin{array}{l}\text { Chlorophyll } \\
(\mu \mathrm{g} / \mathrm{L})\end{array}$ & Comment \\
\hline \multirow[t]{5}{*}{12} & 11 & $21 \mathrm{Jan} 2007$ & & $45^{\circ} 57.866^{\prime} \mathrm{S}, 163^{\circ} 11.051^{\prime} \mathrm{W}$ & SW & sWs & 11 & 13.16 & 4.08 & 37.7 & & \\
\hline & & & & & 30 & $18-24$ & 34.4 & 13.15 & 4.08 & 34.7 & & Above thermocline \\
\hline & & & & & 45 & $8-17$ & 49 & 13.13 & 4.08 & 34.7 & & Small upper chl maximum \\
\hline & & & & & 60 & $2-7$ & 63 & 11.5 & 3.9 & 34.7 & 0.4 & Chl minimum \\
\hline & & & & & 100 & 1 & 105 & 10.5 & 3.9 & 34.7 & 0.07 & $\begin{array}{l}\text { Chl maximum } \\
\text { Lower end of chl maximum }\end{array}$ \\
\hline
\end{tabular}

Time is Universal Time Coordinated. $\mathrm{Chl}=$ chlorophyll. $\mathrm{SW}=$ surface water 
Table T14. Marine mammal sighting information.

\begin{tabular}{|c|c|c|c|c|c|c|c|c|c|}
\hline $\begin{array}{l}\text { Date } \\
(2007)\end{array}$ & $\begin{array}{c}\text { Time } \\
\text { (h) }\end{array}$ & $\begin{array}{c}\text { UTC } \\
\text { offset } \\
\text { (h) }\end{array}$ & Sighting & Location & $\begin{array}{l}\text { Species } \\
\text { code }\end{array}$ & $\begin{array}{l}\text { Number } \\
\text { of animals }\end{array}$ & $\begin{array}{c}\text { Air } \\
\text { gunning }\end{array}$ & $\begin{array}{l}\text { Air guns } \\
\text { stopped }\end{array}$ & $\begin{array}{c}\text { Closest } \\
\text { distance }(m)\end{array}$ \\
\hline 1 Jan & 0016 & -10 & 1 & $27^{\circ} 45.45^{\prime} \mathrm{S}, 133^{\circ} 02.99^{\prime} \mathrm{W}$ & 177 & 15 & No & No & 400 \\
\hline 2 Jan & 1808 & -10 & 2 & $28^{\circ} 20.62^{\prime} \mathrm{S}, 129^{\circ} 58.99^{\prime} \mathrm{W}$ & 177 & 40 & No & No & 1444 \\
\hline 3 Jan & 1415 & -10 & 3 & $28^{\circ} 00.97^{\prime} \mathrm{S}, 125^{\circ} 30.06^{\prime} \mathrm{W}$ & 049 & 1 & No & No & 3823 \\
\hline 3 Jan & 2059 & -10 & 4 & $27^{\circ} 54.28^{\prime} \mathrm{S}, 123^{\circ} 58.6^{\prime} \mathrm{W}$ & 061 & 4 & No & No & 4881 \\
\hline 3 Jan & 2133 & -10 & 5 & $27^{\circ} 53.72^{\prime} \mathrm{S}, 123^{\circ} 51.08^{\prime} \mathrm{W}$ & 049 & 2 & No & No & 6112 \\
\hline 7 Jan & 2039 & -10 & 6 & $28^{\circ} 54.78^{\prime} \mathrm{S}, 119^{\circ} 17.53^{\prime} \mathrm{W}$ & 049 & 9 & No & No & 6816 \\
\hline 9 Jan & 2357 & -10 & 7 & $35^{\circ} 24.71^{\prime} \mathrm{S}, 128^{\circ} 56.66^{\prime} \mathrm{W}$ & 076 & 2 & No & No & 1241 \\
\hline 9 Jan & 2357 & -10 & 8 & $35^{\circ} 24.72^{\prime} \mathrm{S}, 128^{\circ} 56.66^{\prime} \mathrm{W}$ & 177 & 40 & No & No & 6112 \\
\hline 10 Jan & 1800 & -10 & 9 & $37^{\circ} 37.09^{\prime} \mathrm{S}, 132^{\circ} 23.39^{\prime} \mathrm{W}$ & 070 & 2 & No & No & 200 \\
\hline 20 Jan & 2025 & -10 & 10 & $45^{\circ} 57.85^{\prime} \mathrm{S}, 163^{\circ} 11.05^{\prime} \mathrm{W}$ & 035 & 26 & No & No & 20 \\
\hline 22 Jan & 1700 & -11 & 11 & $45^{\circ} 54.32^{\prime} \mathrm{S}, 169^{\circ} 38.47^{\prime} \mathrm{W}$ & 079 & 3 & No & No & 500 \\
\hline 24 Jan & 2148 & -11 & 12 & $45^{\circ} 50.59^{\prime} \mathrm{S}, 176^{\circ} 30.24^{\prime} \mathrm{W}$ & UA & 1 & No & No & 300 \\
\hline 24 Jan & 2222 & -11 & 13 & $45^{\circ} 50.52^{\prime} \mathrm{S}, 176^{\circ} 37.66^{\prime} \mathrm{W}$ & UA & 1 & No & No & 300 \\
\hline 24 Jan & 2228 & -11 & 14 & $45^{\circ} 50.5^{\prime} \mathrm{S}, 176^{\circ} 39.08^{\prime} \mathrm{W}$ & UA & 3 & No & No & 980 \\
\hline 24 Jan & 2258 & -11 & 15 & $45^{\circ} 50.45^{\prime} \mathrm{S}, 176^{\circ} 45.56^{\prime} \mathrm{W}$ & UA & 1 & No & No & 2400 \\
\hline 24 Jan & 2311 & -11 & 16 & $45^{\circ} 50.42^{\prime} \mathrm{S}, 176^{\circ} 48.51^{\prime} \mathrm{W}$ & 035 & 18 & No & No & 1722 \\
\hline 25 Jan & 0007 & -11 & 17 & $45^{\circ} 50.3^{\prime} \mathrm{S}, 177^{\circ} 00.73^{\prime} \mathrm{W}$ & UA & 1 & No & No & 1722 \\
\hline 25 Jan & 0010 & -11 & 18 & $45^{\circ} 50.3^{\prime} \mathrm{S}, 177^{\circ} 01.3^{\prime} \mathrm{W}$ & UA & 1 & No & No & 380 \\
\hline 25 Jan & 0105 & -11 & 19 & $45^{\circ} 50.19^{\prime} \mathrm{S}, 177^{\circ} 13.24^{\prime} \mathrm{W}$ & 079 & 1 & No & No & 5500 \\
\hline 26 Jan & 0718 & -11 & 20 & $45^{\circ} 47.02^{\prime} \mathrm{S}, 176^{\circ} 42.9^{\prime} \mathrm{E}$ & UA & 1 & No & No & 50 \\
\hline 26 Jan & 1734 & -11 & 21 & $45^{\circ} 45.81^{\prime} \mathrm{S}, 174^{\circ} 45.97^{\prime} \mathrm{E}$ & UA & 1 & No & No & 100 \\
\hline 27 Jan & 0213 & -11 & 22 & $45^{\circ} 45.15^{\prime} \mathrm{S}, 173^{\circ} 17.78^{\prime} \mathrm{E}$ & 070 & 2 & No & No & 6112 \\
\hline 27 Jan & 0256 & -11 & 23 & $45^{\circ} 44.95^{\prime} \mathrm{S}, 173^{\circ} 10.29^{\prime} \mathrm{E}$ & 079 & 1 & No & No & 2797 \\
\hline
\end{tabular}

UTC = Universal Time Coordinated. Species codes: $035=$ Globicephala melas (long-finned pilot whale), $049=$ unidentified Ziphiid whale (beaked whale), 061 = Ziphius cavirostris (Cuvier's beaked whale), $070=$ unidentified Balaenoptera (baleen whale), $076=$ Megaptera novaengliae (humpback whale), $079=$ unidentified large whale, $177=$ unidentified small Delphinid (dolphin), UA = unidentified fur seal.

Table T15. Sedimentation estimates, Sites SPG-1-SPG-12.

\begin{tabular}{|c|c|c|c|c|c|}
\hline \multirow[b]{2}{*}{ Site } & \multirow[b]{2}{*}{ Location } & \multirow{2}{*}{$\begin{array}{c}\text { Sediment } \\
\text { thickness } \\
\text { estimate }(m)\end{array}$} & \multirow[b]{2}{*}{$\begin{array}{l}\text { Crust age } \\
\text { (Ma) }\end{array}$} & \multicolumn{2}{|c|}{ Sedimentation estimate } \\
\hline & & & & $\begin{array}{c}\text { Rate } \\
(\mathrm{m} / \mathrm{m} \cdot \mathrm{y} .)\end{array}$ & $\begin{array}{l}\text { Accumulation } \\
\mathrm{mg} /\left(\mathrm{cm}^{2} \cdot \mathrm{k}_{\mathrm{c}} \mathrm{y}\right)\end{array}$ \\
\hline SPG-1 & $23.85^{\circ} \mathrm{S}, 165.64^{\circ} \mathrm{W}$ & 71 & 102.5 & 0.69 & 187 \\
\hline SPG-2 & $26.05^{\circ} \mathrm{S}, 156.78^{\circ} \mathrm{W}$ & 17 & 102.5 & 0.17 & 47 \\
\hline SPG-3 & $27.94^{\circ} \mathrm{S}, 148.59^{\circ} \mathrm{W}$ & 5.5 & 70 & 0.08 & 20 \\
\hline SPG-4 & $26.48^{\circ} \mathrm{S}, 137.94^{\circ} \mathrm{W}$ & 9.5 & 33.5 & 0.28 & 78 \\
\hline SPG-5 & $28.45^{\circ} \mathrm{S}, 131.39^{\circ} \mathrm{W}$ & 16.5 & 24 & 0.69 & 178 \\
\hline SPG-6 & $27.92^{\circ} \mathrm{S}, 123.17^{\circ} \mathrm{W}$ & 15 & 13.5 & 1.11 & 270 \\
\hline SPG-7 & $27.68^{\circ} \mathrm{S}, 117.57^{\circ} \mathrm{W}$ & 1.045 & 6.1 & 0.17 & 35 \\
\hline SPG-9 & $38.06^{\circ} \mathrm{S}, 133.09^{\circ} \mathrm{W}$ & 19.8 & 39 & 0.51 & 153 \\
\hline SPG-10 & $39.31^{\circ} \mathrm{S}, 139.80^{\circ} \mathrm{W}$ & 21.4 & 58 & 0.37 & 105 \\
\hline SPG-11 & $41.85^{\circ} \mathrm{S}, 153.11^{\circ} \mathrm{W}$ & 67 & 75 & 0.89 & 246 \\
\hline SPG-12 & $45.96^{\circ} \mathrm{S}, 163.18^{\circ} \mathrm{W}$ & 130 & 73 & 1.78 & 494 \\
\hline
\end{tabular}

